\title{
\#USGS
}

Prepared in cooperation with the Kansas Department of Wildlife,

Parks and Tourism and the U.S. Fish and Wildlife Service

\section{Streamflow Alteration at Selected Sites in Kansas}

Scientific Investigations Report 2017-5046

U.S. Department of the Interior

U.S. Geological Survey 
Cover photograph: Chapman Creek near Chapman, Kansas (photograph taken by Dirk Hargadine, U.S. Geological Survey, on January 7, 2014). 


\section{Streamflow Alteration at Selected Sites in Kansas}

By Kyle E. Juracek and Ken Eng

Prepared in cooperation with the Kansas Department of Wildlife, Parks and Tourism and the U.S. Fish and Wildlife Service

Scientific Investigations Report 2017-5046 


\title{
U.S. Department of the Interior \\ RYAN K. ZINKE, Secretary
}

\section{U.S. Geological Survey William H. Werkheiser, Acting Director}

\author{
U.S. Geological Survey, Reston, Virginia: 2017
}

For more information on the USGS - the Federal source for science about the Earth, its natural and living resources, natural hazards, and the environment-visit https://www.usgs.gov or call 1-888-ASK-USGS.

For an overview of USGS information products, including maps, imagery, and publications, visit https://store.usgs.gov/.

Any use of trade, firm, or product names is for descriptive purposes only and does not imply endorsement by the U.S. Government.

Although this information product, for the most part, is in the public domain, it also may contain copyrighted materials as noted in the text. Permission to reproduce copyrighted items must be secured from the copyright owner.

Suggested citation:

Juracek, K.E., and Eng, Ken, 2017, Streamflow alteration at selected sites in Kansas: U.S. Geological Survey Scientific Investigations Report 2017-5046, 75 p., https://doi.org/10.3133/sir20175046.

ISSN 2328-0328 (online) 


\section{Acknowledgments}

This study was made possible with the support of the Kansas Department of Wildlife, Parks and Tourism and the U.S. Fish and Wildlife Service. For the collection and provision of groundwaterlevel data, the authors thank Western Kansas Groundwater Management District \#1, Equus Beds Groundwater Management District \#2, Southwest Kansas Groundwater Management District \#3, Northwest Kansas Groundwater Management District \#4, Big Bend Groundwater Management District \#5, the Kansas Department of Agriculture's Division of Water Resources, and the Kansas Geological Survey. For the collection of the many decades of streamflow data, the authors thank the past and current U.S. Geological Survey hydrologic technicians and hydrologists and acknowledge the support of the many Federal, State, Tribal, and local partner agencies that made this data collection and analysis possible. 


\section{Contents}

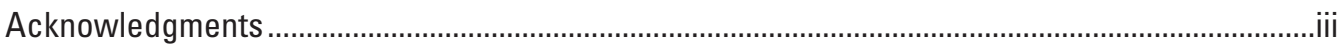

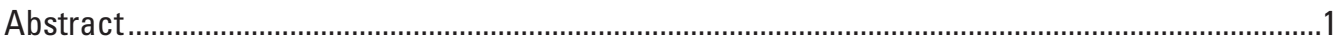

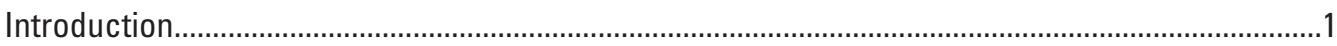

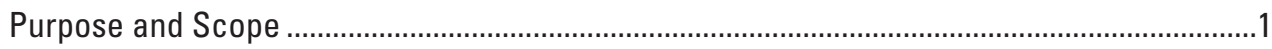

Description of Kansas ...................................................................................................

Methods

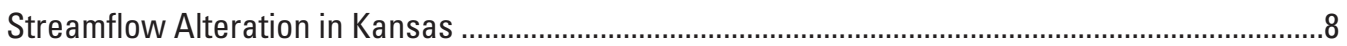

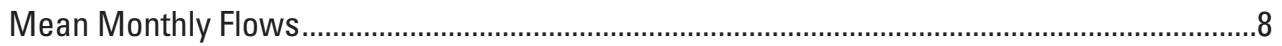

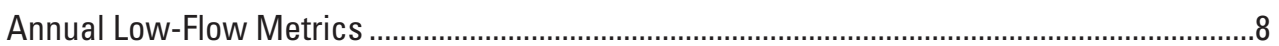

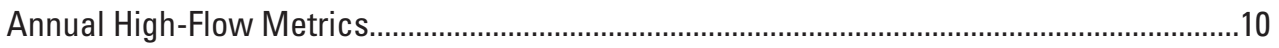

Other Annual Flow Metrics ...................................................................................................11

Effects of Human Disturbances on Streamflow and Habitat Implications.......................................11

Groundwater Pumping from the High Plains Aquifer ........................................................12

Agricultural Land-Management Practices.........................................................................12

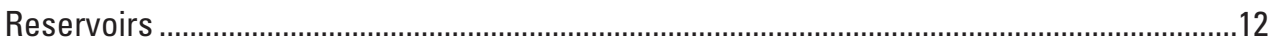

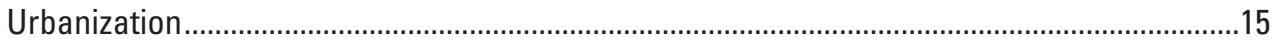

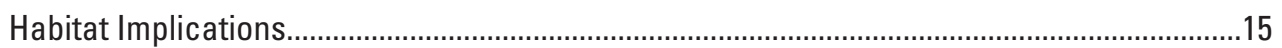

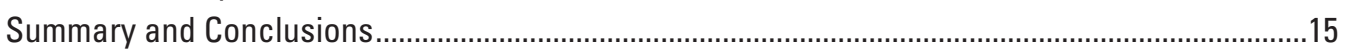

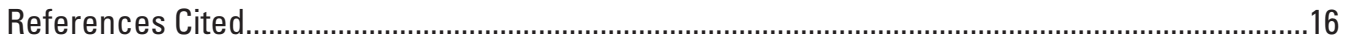

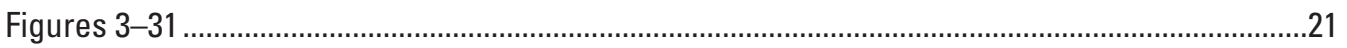

Appendix 1. Observed/Expected (O/E) Ratio Values for Streamflow Metrics Assessed in This Study ……….........................................................................................................

\section{Figures}

1. Map showing land use (2011) and selected U.S. Geological Survey streamgages in Kansas.

2. Map showing groundwater-level changes in the High Plains aquifer from predevelopment to 2013.

32. Map showing large reservoirs and selected U.S. Geological Survey streamgages in Kansas.

Figures at the back of this report

3. Map showing condition of mean January flow normalized by drainage area for 129 streamgages in Kansas

4. Map showing condition of mean February flow normalized by drainage area for 129 streamgages in Kansas

5. Map showing condition of mean March flow normalized by drainage area for 129 streamgages in Kansas

6. Map showing condition of mean April flow normalized by drainage area for 129 streamgages in Kansas

7. Map showing condition of mean May flow normalized by drainage area for 129 streamgages in Kansas

8. Map showing condition of mean June flow normalized by drainage area for 129 streamgages in Kansas 
9. Map showing condition of mean July flow normalized by drainage area for 129 streamgages in Kansas .

10. Map showing condition of mean August flow normalized by drainage area for 129 streamgages in Kansas ..

11. Map showing condition of mean September flow normalized by drainage area for 129 streamgages in Kansas .

12. Map showing condition of mean October flow normalized by drainage area for 129 streamgages in Kansas.

13. Map showing condition of mean November flow normalized by drainage area for 129 streamgages in Kansas .....

14. Map showing condition of mean December flow normalized by drainage area for 129 streamgages in Kansas .

15. Map showing condition of the average annual number of flow pulses less than the 10th percentile metric for 129 streamgages in Kansas

16. Map showing condition of the average duration of flow pulses less than the 10th percentile metric for 129 streamgages in Kansas.

17. Map showing condition of the average magnitude of flow pulses less than the 10th percentile metric for 129 streamgages in Kansas

18. Map showing condition of the average annual number of flow pulses less than the 25th percentile metric for 129 streamgages in Kansas

19. Map showing condition of the average duration of flow pulses less than the 25th percentile metric for 129 streamgages in Kansas

20. Map showing condition of the average magnitude of flow pulses less than the 25th percentile metric for 129 streamgages in Kansas

21. Map showing condition of the average annual number of flow pulses greater than the 75th percentile metric for 129 streamgages in Kansas .

22. Map showing condition of the average duration of flow pulses greater than the 75th percentile metric for 129 streamgages in Kansas

23. Map showing condition of the average magnitude of flow pulses greater than the 75th percentile metric for 129 streamgages in Kansas

24. Map showing condition of the average annual number of flow pulses greater than the 90th percentile metric for 129 streamgages in Kansas

25. Map showing condition of the average duration of flow pulses greater than the 90th percentile metric for 129 streamgages in Kansas

26. Map showing condition of the average magnitude of flow pulses greater than the 90th percentile metric for 129 streamgages in Kansas

27. Map showing condition of the percentage of flow that is base flow metric for 129 streamgages in Kansas

28. Map showing condition of the 10 th percentile flow normalized by drainage area metric for 129 streamgages in Kansas.

29. Map showing condition of the median flow normalized by drainage area metric for 129 streamgages in Kansas.

30. Map showing condition of the 90th percentile flow normalized by drainage area metric for 129 streamgages in Kansas.

31. Map showing condition of the coefficient of variation of daily flows metric for 129 streamgages in Kansas 


\section{Tables}

1. Streamflow metrics used in this study

2. U.S. Geological Survey streamgages used in this study to examine streamflow

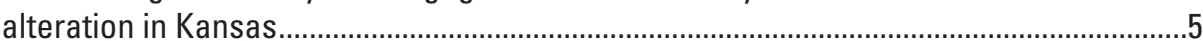

3. Model performance criteria..............................................................................................

4. Summary of alteration of mean monthly flows for 129 streamgages in Kansas .............10

5. Summary of alteration of annual low-flow metrics for 129 streamgages in Kansas ......10

6. Summary of alteration of annual high-flow metrics for 129 streamgages in Kansas .....11

7. Summary of alteration of other annual flow metrics for 129 streamgages in Kansas....11

8. Summary of streamflow alteration downstream from 20 large reservoirs in Kansas. ...13

\section{Appendix Tables}

1-1. Observed/Expected (O/E) ratio values for the January, February, March, and April flow metrics assessed in this study

1-2. Observed/Expected (O/E) ratio values for the May, June, July, and August flow metrics assessed in this study....

1-3. Observed/Expected (O/E) ratio values for the September, October, November, and December flow metrics assessed in this study

1-4. Observed/Expected (O/E) ratio values for the 10th percentile flow metrics assessed in this study

1-5. Observed/Expected (O/E) ratio values for the 25 th percentile flow metrics assessed in this study

1-6. Observed/Expected (O/E) ratio values for the 75th percentile flow metrics assessed in this study

1-7. Observed/Expected (O/E) ratio values for the 90th percentile flow metrics assessed in this study

1-8. Observed/Expected (O/E) ratio values for five annual flow metrics assessed in this study 


\section{Conversion Factors}

U.S. customary units to International System of Units

\begin{tabular}{|c|c|c|}
\hline Multiply & By & To obtain \\
\hline \multicolumn{3}{|c|}{ Length } \\
\hline inch (in.) & 2.54 & centimeter $(\mathrm{cm})$ \\
\hline inch (in.) & 25.4 & millimeter (mm) \\
\hline foot $(\mathrm{ft})$ & 0.3048 & meter $(\mathrm{m})$ \\
\hline mile (mi) & 1.609 & kilometer (km) \\
\hline \multicolumn{3}{|c|}{ Area } \\
\hline square mile $\left(\mathrm{mi}^{2}\right)$ & 259.0 & hectare (ha) \\
\hline square mile $\left(\mathrm{mi}^{2}\right)$ & 2.590 & square kilometer $\left(\mathrm{km}^{2}\right)$ \\
\hline \multicolumn{3}{|c|}{ Flow rate } \\
\hline cubic foot per second $\left(\mathrm{ft}^{3} / \mathrm{s}\right)$ & 0.02832 & cubic meter per second $\left(\mathrm{m}^{3} / \mathrm{s}\right)$ \\
\hline
\end{tabular}





\title{
Streamflow Alteration at Selected Sites in Kansas
}

\author{
By Kyle E. Juracek and Ken Eng
}

\section{Abstract}

An understanding of streamflow alteration in response to various disturbances is necessary for the effective management of stream habitat for a variety of species in Kansas. Streamflow alteration can have negative ecological effects. Using a modeling approach, streamflow alteration was assessed for 129 selected U.S. Geological Survey streamgages in the State for which requisite streamflow and basin-characteristic information was available. The assessment involved a comparison of the observed condition from 1980 to 2015 with the predicted expected (least-disturbed) condition for 29 streamflow metrics. The metrics represent various characteristics of streamflow including average flow (annual, monthly) and low and high flow (frequency, duration, magnitude).

Streamflow alteration in Kansas was indicated locally, regionally, and statewide. Given the absence of a pronounced trend in annual precipitation in Kansas, a precipitation-related explanation for streamflow alteration was not supported. Thus, the likely explanation for streamflow alteration was human activity. Locally, a flashier flow regime (typified by shorter lag times and more frequent and higher peak discharges) was indicated for three streamgages with urbanized basins that had higher percentages of impervious surfaces than other basins in the State. The combination of localized reservoir effects and regional groundwater pumping from the High Plains aquifer likely was responsible, in part, for diminished conditions indicated for multiple streamflow metrics in western and central Kansas. Statewide, the implementation of agricultural landmanagement practices to reduce runoff may have been responsible, in part, for a diminished duration and magnitude of high flows. In central and eastern Kansas, implemented agricultural land-management practices may have been partly responsible for an inflated magnitude of low flows at several sites.

\section{Introduction}

The physical habitat of streams and the type, distribution, and abundance of resident aquatic organisms are fundamentally determined by streamflow (Poff and others, 1997; Bunn and Arthington, 2002). The ecological integrity of streams can be adversely affected if the natural flow regime is altered (Poff and Zimmerman, 2010; Carlisle and others, 2011). The flow regime of a stream is determined by the magnitude, frequency, duration, timing, and rate of change of flows (Poff and others, 1997). Effective management to protect aquatic organism populations and habitats in Kansas requires an understanding of streamflow conditions and how those conditions may have changed in response to various disturbances. Throughout the State, the use and management of water resources to satisfy human needs have directly or indirectly affected streamflow. Examples of human activity that affect streamflow include surface-water diversions, reservoir construction and operation, groundwater pumping from aquifers, agricultural land-management practices, and urbanization.

A 1.5-year study by the U.S. Geological Survey (USGS), in cooperation with the Kansas Department of Wildlife, Parks and Tourism (KDWPT) and the U.S. Fish and Wildlife Service (FWS), was begun in 2016 to assess streamflow alteration at USGS streamgage sites throughout Kansas. The assessment, which provides an indication of where and how streamflow conditions have changed, can aid in management decisions for stream habitat prioritization, conservation, and restoration.

\section{Purpose and Scope}

The purpose of this report is to present the results of the USGS study to assess streamflow alteration at 129 selected USGS streamgage sites throughout Kansas. For each site, streamflow alteration was assessed by comparing the observed condition from 1980 to 2015 with the predicted expected (least-disturbed) condition for 29 metrics that account for various aspects of streamflow.

Results presented in this report are intended to provide some of the information needed by the KDWPT and FWS to support more effective management of stream habitats for various aquatic organisms. Nationally, the methods and results presented in this report can provide guidance and perspective for future studies concerned with streamflow alteration and the habitat implications thereof.

\section{Description of Kansas}

The study covered the entire State of Kansas, an area of about 82,000 square miles. Within the State, major rivers include the Arkansas, Cimarron, Kansas, Marais des Cygnes, Neosho, Republican, Saline, Smoky Hill, Solomon, Verdigris, 
and Walnut (fig. 1). Terrain varies across the State and includes flat plains, rolling hills, sandhills, and steep slopes (Moody and others, 1986). Land use is predominantly cropland and grassland (fig. 1; Jin and others, 2013).

The climate in Kansas is characterized by well-defined seasons and variable precipitation. On average, annual precipitation ranges from about 15 inches (in.) in extreme western Kansas to about 45 in. in the southeast (National Oceanic and Atmospheric Administration, 2016). From 1950 to 2000, there was not a pronounced trend in annual precipitation for Kansas (Brunsell and others, 2010). Moreover, from 1951 to 2013 , a pronounced trend in annual precipitation was not evident for southwestern and south-central Kansas (Juracek, 2015). During the 21 st century, global warming is projected to result in minimal change in average annual precipitation in the State, although the amount of precipitation in individual storm events may increase (Walsh and others, 2014). Increased temperatures may result in increased evapotranspiration.

The High Plains aquifer underlies much of western and central Kansas (fig. 2). The aquifer is characterized as a watertable aquifer that primarily consists of near-surface sand and gravel deposits (Weeks and others, 1988). Extensive use of groundwater from the aquifer, primarily for irrigated agriculture, began in the 1950s and continues to the present (Kansas Water Resources Board, 1958, 1960; Gutentag and others,
1984; Kenny and Juracek, 2013). Groundwater withdrawals for irrigation far in excess of natural recharge are the primary cause of groundwater-level declines in the aquifer (Gutentag and others, 1984; Young and others, 2005; Whittemore and others, 2016). In some locations, groundwater-level declines of 50 to 150 feet or more have occurred (fig. 2; McGuire, 2014).

\section{Methods}

Streamflow alteration was assessed using the reference condition approach (Bailey and others, 2004; Carlisle and others, 2010), which is based on the principle that expected reference conditions for basins influenced by hydrologic modifications (for example, groundwater withdrawals or land-use change) can be predicted using statistical models developed for a population of reference (least-disturbed) basins. With this approach, streamflow alteration at selected streamgages was quantified as the difference between the observed flow conditions and the predicted expected reference conditions. In this study, the period from 1980 to 2015 was examined to provide an assessment of flow alteration for recent conditions in Kansas.

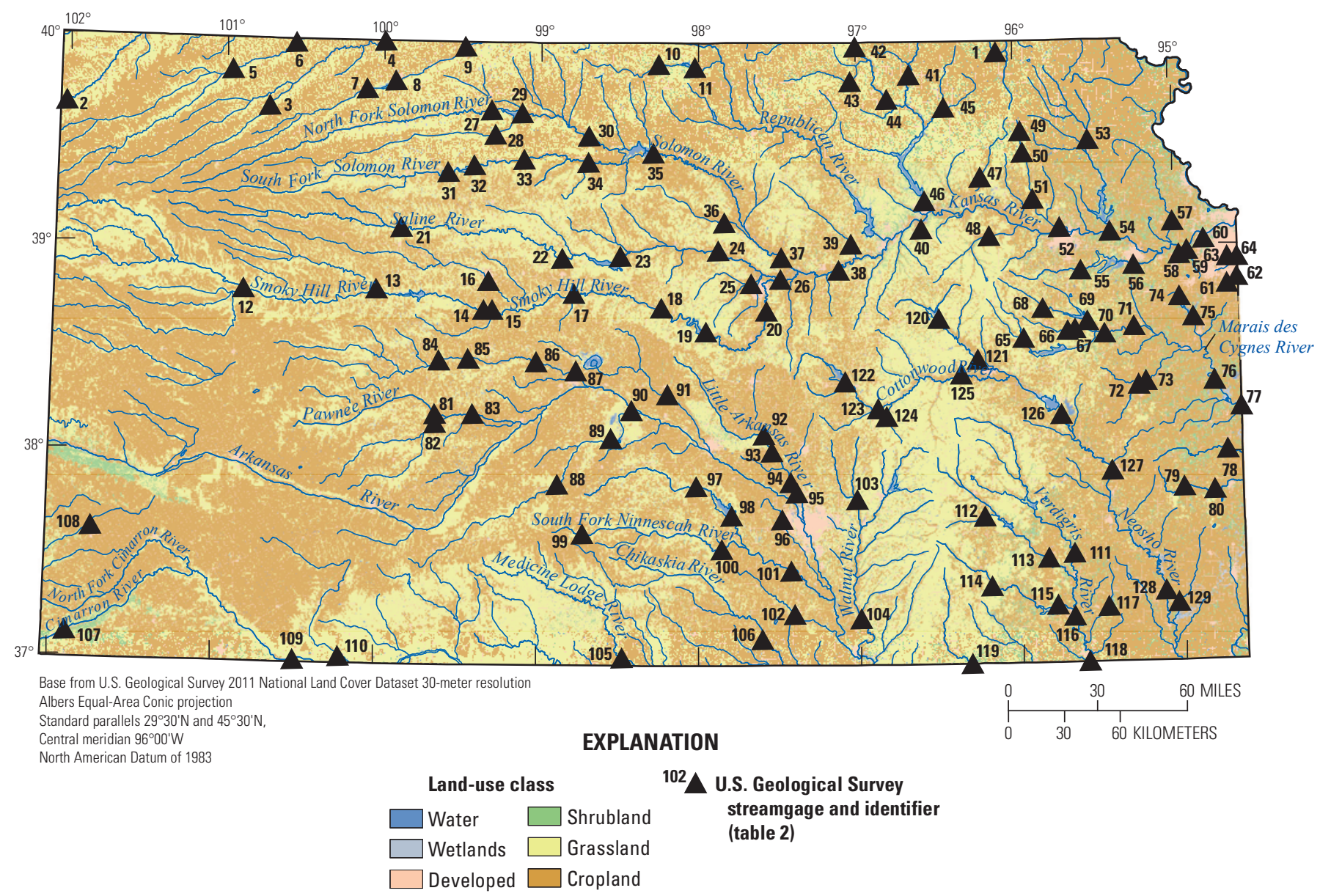

Figure 1. Land use (2011) and selected U.S. Geological Survey streamgages in Kansas. 


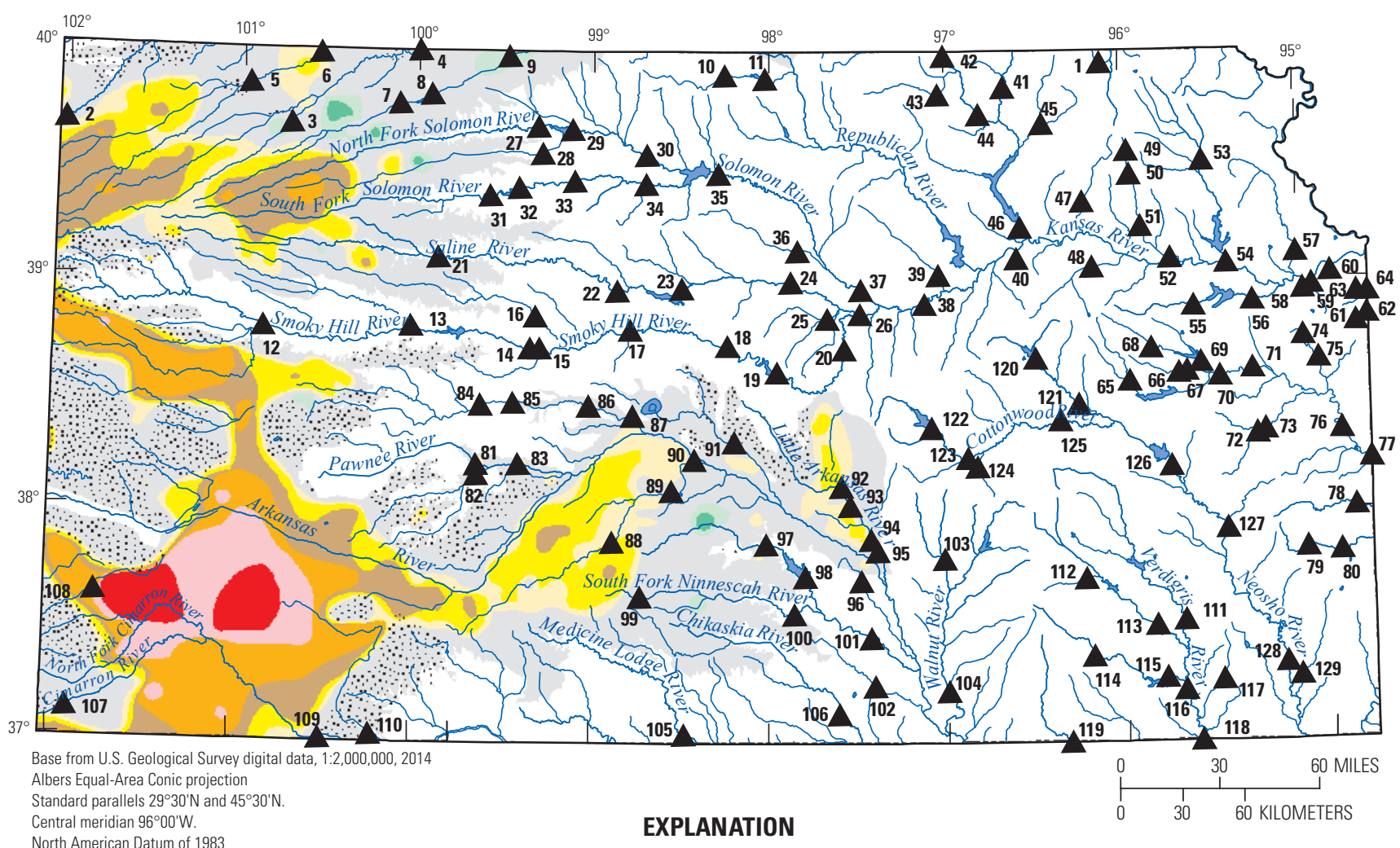

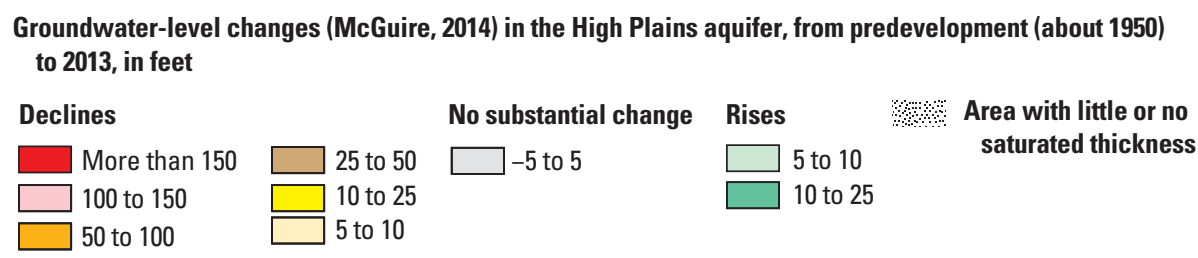

${ }^{102}$ U.S. Geological Survey streamgage and identifier (table 2)

Figure 2. Groundwater-level changes in the High Plains aquifer from predevelopment to 2013 (Source: McGuire, 2014).

To assess streamflow alteration various flow metrics were used that were computed from daily-flow time series and are indicative of key aspects of the flow regime (Carlisle and others, 2010). Twenty-nine metrics that represent various characteristics of flow, including median or mean flow (annual, monthly), daily flow variability, low and high flow (frequency, duration, magnitude), and base flow, were selected (table 1).

Two criteria were used in the selection of USGS streamgages to be included in the assessment of streamflow alteration in Kansas. First, the streamgages were required to have a minimum of 12 years of complete daily streamflow record from 1980 to 2015 . This minimum was used instead of the 15 years recommended by Kennard and others (2010) because of the additional number and spatial coverage of streamgages that could be included in the analysis by lowering the threshold. Moreover, the differences in bias, precision, and accuracy for 12 years as compared to 15 years were minimal (Kennard and others, 2010). Second, the streamgages also needed to be listed in the Geospatial Attributes of Gages for Evaluating Streamflow, version 2 (GAGES-II) database (Falcone, 2011) so that the associated basin characteristics required for the analysis could be used. The GAGES-II database provides more than 300 basin characteristics for streamgages with a basin size of 50,000 square kilometers (about 19,300 square miles) or less. Use of the two criteria resulted in the selection of 129 streamgages (fig. 1; table 2). Each of the streamgages provides long-term daily flow data that were collected as part of the USGS national streamgaging network using standard USGS methods (Turnipseed and Sauer, 2010). The flow data are available from the USGS National Water Information System (NWIS; U.S. Geological Survey, 2016). The observed values of the 29 flow metrics for each streamgage were calculated using daily flow data downloaded from NWIS using a program by Granato (2009).

Estimates of the expected reference value for each flow metric for each streamgage were predicted with statistical models that used basin characteristics, such as climate, topography, and soils, as explanatory variables (Carlisle and others, 
Streamflow Alteration at Selected Sites in Kansas

Table 1. Streamflow metrics used in this study.

\begin{tabular}{|c|c|}
\hline Metric & Description \\
\hline P50 & Median annual flow normalized by drainage area. \\
\hline CV_FLOW & Coefficient of variation of daily flows. \\
\hline AVG_JAN & Mean January flow normalized by drainage area. \\
\hline AVG_FEB & Mean February flow normalized by drainage area. \\
\hline AVG_MAR & Mean March flow normalized by drainage area. \\
\hline AVG_APR & Mean April flow normalized by drainage area. \\
\hline AVG_MAY & Mean May flow normalized by drainage area. \\
\hline AVG_JUN & Mean June flow normalized by drainage area. \\
\hline AVG_JUL & Mean July flow normalized by drainage area. \\
\hline AVG_AUG & Mean August flow normalized by drainage area. \\
\hline AVG_SEP & Mean September flow normalized by drainage area. \\
\hline AVG_OCT & Mean October flow normalized by drainage area. \\
\hline AVG_NOV & Mean November flow normalized by drainage area. \\
\hline AVG_DEC & Mean December flow normalized by drainage area. \\
\hline PUL_NO_P90 & Average annual number of flow pulses greater than the 90th percentile. \\
\hline PUL_NO_P75 & Average annual number of flow pulses greater than the 75 th percentile. \\
\hline PUL_NO_P25 & Average annual number of flow pulses less than the 25 th percentile. \\
\hline PUL_NO_P10 & Average annual number of flow pulses less than the 10th percentile. \\
\hline P10 & 10th percentile flow normalized by drainage area. \\
\hline P90 & 90th percentile flow normalized by drainage area. \\
\hline PER_BSFL ${ }^{a}$ & Percentage of flow that is base flow. \\
\hline PUL_LEN_P10 & Average duration of flow pulses less than the 10th percentile. \\
\hline PUL_LEN_P25 & Average duration of flow pulses less than the 25 th percentile. \\
\hline PUL_LEN_P75 & Average duration of flow pulses greater than the 75 th percentile. \\
\hline PUL_LEN_P90 & Average duration of flow pulses greater than the 90th percentile. \\
\hline PUL_FLOW_P10 & Average magnitude of flow pulses less than the 10th percentile, normalized by drainage area. \\
\hline PUL_FLOW_P25 & Average magnitude of flow pulses less than the 25 th percentile, normalized by drainage area. \\
\hline PUL_FLOW_P75 & Average magnitude of flow pulses greater than the 75 th percentile, normalized by drainage area. \\
\hline PUL_FLOW_P90 & Average magnitude of flow pulses greater than the 90th percentile, normalized by drainage area. \\
\hline
\end{tabular}

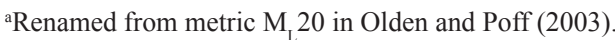

2010). Statistical models were developed using 1,443 previously identified streamgages (Falcone and others, 2010) with least-disturbed basins (that is, reference quality) on perennial, intermittent, and ephemeral streams across the contiguous United States. For each reference site, 176 geospatial characteristics representing natural (that is, excluding land cover and other anthropogenic activities) physical attributes of the contributing basin were computed (Falcone, 2011).

Separate random forest (Cutler and others, 2007) models were developed for each flow metric using the 1,443 reference sites, with the observed metric as the dependent variable and the natural geospatial characteristics as predictors. The random forest models were implemented in Matlab using a script by Jaiantilal (2009). Modeling proceeded as follows: First, 30 random forest models, each with 1,000 trees, were fit using all 176 basin characteristics and a randomly selected subset of
90 percent of the reference sites. Then, for each random forest model, the importance of each predictor variable was computed by measuring the decrease in model performance as that variable was randomly permuted (Cutler and others, 2007). The 20 predictors with the highest average importance among the 30 initial models were selected for the final model (Eng and others, in press). For each flow metric, the final model included 100 random forest fits, each with 1,000 trees, trained on a randomly selected subset of 90 percent of the reference sites. For each random forest model fit, 10 percent of the sites were set aside for validation of model performance and were selected in equal numbers from nine aggregated ecoregions of the contiguous United States (Falcone, 2011) to ensure even geographic distribution.

Model performance was evaluated using four independent (Pearson $r<0.3$ ) criteria. These were Nash-Sutcliffe 
Table 2. U.S. Geological Survey streamgages used in this study to examine streamflow alteration in Kansas.

[USGS, U.S. Geological Survey; km², square kilometer]

\begin{tabular}{|c|c|c|c|c|}
\hline $\begin{array}{c}\text { Site } \\
\text { identifier } \\
\text { (fig. 1) }\end{array}$ & $\begin{array}{c}\text { USGS } \\
\text { streamgage } \\
\text { number }\end{array}$ & USGS streamgage name & $\begin{array}{l}\text { Drainage area } \\
\qquad\left(\mathrm{km}^{2}\right)\end{array}$ & $\begin{array}{c}\text { Complete years } \\
\text { of record } \\
\text { (since 1980) }\end{array}$ \\
\hline 1 & 06814000 & Turkey Creek near Seneca, Kansas & 713.8 & 36 \\
\hline 2 & 06827000 & South Fork Republican River near Colorado-Kansas State line, Kansas & $5,313.8$ & 13 \\
\hline 3 & 06844900 & South Fork Sappa Creek near Achilles, Kansas & $1,153.5$ & 29 \\
\hline 4 & 06845110 & Sappa Creek near Lyle, Kansas & $3,782.1$ & 20 \\
\hline 6 & 06846500 & Beaver Creek at Cedar Bluffs, Kansas & $4,357.8$ & 36 \\
\hline 7 & 06847900 & Prairie Dog Creek above Keith Sebelius Lake, Kansas & $1,536.2$ & 36 \\
\hline 8 & 06848000 & Prairie Dog Creek at Norton, Kansas & $1,808.4$ & 22 \\
\hline 9 & 06848500 & Prairie Dog Creek near Woodruff, Kansas & $2,575.4$ & 36 \\
\hline 10 & 06853800 & White Rock Creek near Burr Oak, Kansas & 589.4 & 36 \\
\hline 14 & 06862700 & Smoky Hill River near Schoenchen, Kansas & $14,327.7$ & 36 \\
\hline 15 & 06862850 & Smoky Hill River below Schoenchen, Kansas & $14,460.8$ & 34 \\
\hline 16 & 06863500 & Big Creek near Hays, Kansas & $1,417.3$ & 36 \\
\hline 17 & 06864050 & Smoky Hill River near Bunker Hill, Kansas & $18,025.1$ & 31 \\
\hline 18 & 06864500 & Smoky Hill River at Ellsworth, Kansas & $19,334.8$ & 36 \\
\hline 19 & 06865500 & Smoky Hill River near Langley, Kansas & $20,074.1$ & 36 \\
\hline 20 & 06866500 & Smoky Hill River near Mentor, Kansas & $20,903.3$ & 36 \\
\hline 21 & 06866900 & Saline River near WaKeeney, Kansas & $1,801.6$ & 34 \\
\hline 22 & 06867000 & Saline River near Russell, Kansas & 3,857 & 36 \\
\hline 29 & 06871800 & North Fork Solomon River at Kirwin, Kansas & $3,609.5$ & 22 \\
\hline 30 & 06872500 & North Fork Solomon River at Portis, Kansas & $6,217.1$ & 34 \\
\hline 31 & 06873000 & South Fork Solomon River above Webster Reservoir, Kansas & $2,698.8$ & 36 \\
\hline 32 & 06873200 & South Fork Solomon River below Webster Reservoir, Kansas & $3,014.5$ & 22 \\
\hline 33 & 06873460 & South Fork Solomon River at Woodston, Kansas & $4,080.1$ & 36 \\
\hline 34 & 06874000 & South Fork Solomon River at Osborne, Kansas & $5,102.3$ & 36 \\
\hline 35 & 06875900 & Solomon River near Glen Elder, Kansas & $13,705.5$ & 36 \\
\hline 36 & 06876700 & Salt Creek near Ada, Kansas & $1,056.4$ & 36 \\
\hline 37 & 06876900 & Solomon River at Niles, Kansas & $17,487.5$ & 36 \\
\hline 38 & 06877600 & Smoky Hill River at Enterprise, Kansas & $49,592.2$ & 36 \\
\hline 39 & 06878000 & Chapman Creek near Chapman, Kansas & 776.4 & 36 \\
\hline 40 & 06879650 & Kings Creek near Manhattan, Kansas & 11.5 & 36 \\
\hline 41 & 06882510 & Big Blue River at Marysville, Kansas & $12,371.3$ & 31 \\
\hline 42 & 06884025 & Little Blue River at Hollenberg, Kansas & 7,172 & 35 \\
\hline 43 & 06884200 & Mill Creek at Washington, Kansas & 908.4 & 36 \\
\hline
\end{tabular}


Table 2. U.S. Geological Survey streamgages used in this study to examine streamflow alteration in Kansas.-Continued

[USGS, U.S. Geological Survey; $\mathrm{km}^{2}$, square kilometer]

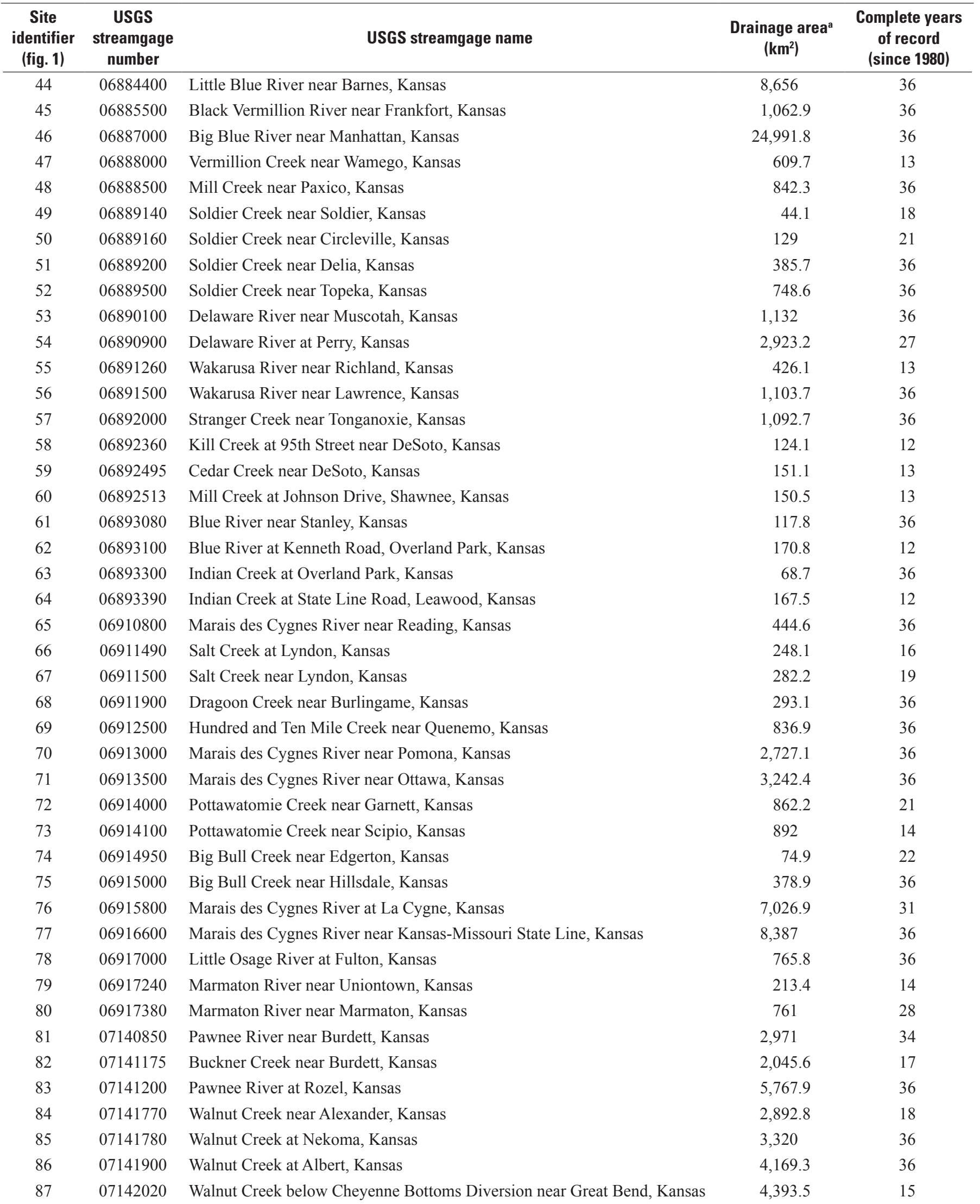


Table 2. U.S. Geological Survey streamgages used in this study to examine streamflow alteration in Kansas.-Continued

[USGS, U.S. Geological Survey; km², square kilometer]

\begin{tabular}{|c|c|c|c|c|}
\hline $\begin{array}{c}\text { Site } \\
\text { identifier } \\
\text { (fig. 1) }\end{array}$ & $\begin{array}{c}\text { USGS } \\
\text { streamgage } \\
\text { number }\end{array}$ & USGS streamgage name & $\begin{array}{l}\text { Drainage area } \\
\qquad\left(\mathrm{km}^{2}\right)\end{array}$ & $\begin{array}{c}\text { Complete years } \\
\text { of record } \\
\text { (since 1980) }\end{array}$ \\
\hline 88 & 07142300 & Rattlesnake Creek near Macksville, Kansas & $1,819.9$ & 36 \\
\hline 89 & 07142575 & Rattlesnake Creek near Zenith, Kansas & $2,685.8$ & 36 \\
\hline 90 & 07142620 & Rattlesnake Creek near Raymond, Kansas & $3,166.1$ & 18 \\
\hline 91 & 07143300 & Cow Creek near Lyons, Kansas & $1,872.9$ & 36 \\
\hline 93 & 07143672 & Little Arkansas River at Highway 50 near Halstead, Kansas & $2,003.4$ & 20 \\
\hline 94 & 07144100 & Little Arkansas River near Sedgwick, Kansas & $3,200.4$ & 22 \\
\hline 95 & 07144200 & Little Arkansas River at Valley Center, Kansas & $3,377.3$ & 36 \\
\hline 96 & 07144480 & Cowskin Creek at 119th Street at Wichita, Kansas & 221.8 & 14 \\
\hline 97 & 07144780 & North Fork Ninnescah River above Cheney Reservoir, Kansas & $2,078.9$ & 36 \\
\hline 101 & 07145500 & Ninnescah River near Peck, Kansas & $5,527.6$ & 36 \\
\hline 102 & 07145700 & Slate Creek at Wellington, Kansas & 399.8 & 36 \\
\hline 103 & 07147070 & Whitewater River at Towanda, Kansas & $1,096.5$ & 36 \\
\hline 104 & 07147800 & Walnut River at Winfield, Kansas & $4,864.7$ & 36 \\
\hline 105 & 07149000 & Medicine Lodge River near Kiowa, Kansas & $2,291.2$ & 36 \\
\hline 106 & 07151500 & Chikaskia River near Corbin, Kansas & 2,109 & 36 \\
\hline 107 & 07155590 & Cimarron River near Elkhart, Kansas & $7,554.3$ & 33 \\
\hline 108 & 07156220 & Bear Creek near Johnson, Kansas & $2,132.4$ & 18 \\
\hline 109 & 07156900 & Cimarron River near Forgan, Oklahoma & $17,944.5$ & 35 \\
\hline 116 & 07170500 & Verdigris River at Independence, Kansas & $7,358.4$ & 36 \\
\hline 117 & 07170700 & Big Hill Creek near Cherryvale, Kansas & 94.8 & 33 \\
\hline 118 & 07170990 & Verdigris River at Coffeyville, Kansas & $8,548.4$ & 13 \\
\hline 119 & 07172000 & Caney River near Elgin, Kansas & $1,110.2$ & 36 \\
\hline 120 & 07179500 & Neosho River at Council Grove, Kansas & 686 & 36 \\
\hline 121 & 07179730 & Neosho River near Americus, Kansas & $1,600.3$ & 36 \\
\hline 122 & 07179795 & North Cottonwood River below Marion Lake, Kansas & 534.6 & 36 \\
\hline 123 & 07180400 & Cottonwood River near Florence, Kansas & $1,935.7$ & 36 \\
\hline 124 & 07180500 & Cedar Creek near Cedar Point, Kansas & 275.5 & 36 \\
\hline 125 & 07182250 & Cottonwood River near Plymouth, Kansas & 4,477 & 36 \\
\hline 126 & 07182510 & Neosho River at Burlington, Kansas & $7,882.4$ & 36 \\
\hline 127 & 07183000 & Neosho River near Iola, Kansas & $9,917.6$ & 36 \\
\hline 128 & 07183500 & Neosho River near Parsons, Kansas & $12,544.2$ & 36 \\
\hline 129 & 07184000 & Lightning Creek near McCune, Kansas & 510.8 & 36 \\
\hline
\end{tabular}

aDrainage areas from Falcone (2011). 
efficiency (NSE, Nash and Sutcliffe, 1970), percent bias (Moriasi and others, 2007), mean observed-to-expected (O/E) values (Carlisle and others, 2011), and the standard deviation (SD) of $\mathrm{O} / \mathrm{E}$ values. These criteria were calculated on each randomly chosen set of 100 validation sites and then averaged for each flow metric. For simplicity, a single composite performance measure also was calculated by standardizing the four criteria to a 0 -to- 1 scale and computing their sum, with the highest scores indicating superior performance. All NSE negative values were set to zero so that the range was bound between 0 and 1 . Values for percent bias were bound between \pm 100 , divided by 100 , and their absolute values were subtracted from 1 . The bounds for mean $\mathrm{O} / \mathrm{E}$ were 0 and 2 . Values between 0 and 1 were unscaled, and values from 1 to 2 were subtracted from 2 . The bounds for the $\mathrm{SD}$ of $\mathrm{O} / \mathrm{E}$ were set at 0 and 0.5 and scaled from 0 to 1 , where a value of 1 corresponds to a SD of 0 and a value of 0 corresponds to a SD of 0.5 or greater.

For the majority of the models (21 of 29) for the flow metrics, performance was either good or very good (table 3 ) and these were the most predictable metrics (as defined by Eng and others, in press). Model performance was fair for 7 metrics (table 3). The model for the baseflow metric (PER_ BSFL) performed poorly. Poor model performance for low flow estimation has been reported elsewhere by Eng and Milly (2007) and Newman and others (2015). Based on an assessment of regional variability in hydrologic model performance for the contiguous United States, Newman and others (2015) concluded that the main factors affecting the variation in model performance were aridity, precipitation intermittency, snowmelt contribution, and runoff seasonality. In addition, other factors that contribute to poor model performance for low and base flow estimation include the inherent measurement error for low flows and a lack of good subsurface metrics that describe aquifer hydraulic properties.

Flow alteration at the streamgages for each of the 29 flow metrics (table 1) was quantified by the ratio of the observed value to the predicted expected value $(\mathrm{O} / \mathrm{E})$. The error bounds of each model were determined by taking the 10th and 90th percentile values from histograms of all validation $\mathrm{O} / \mathrm{E}$ values. These bounds represent thresholds beyond which anthropogenic alteration could be reliably distinguished from model error. Thus, for this study, a flow metric was considered anthropogenically altered only if the $\mathrm{O} / \mathrm{E}$ value was equal to or greater than the 90th percentile threshold (considered to be inflated) or equal to or less than the 10th percentile threshold (considered to be diminished).

\section{Streamflow Alteration in Kansas}

Results of the analysis that used 29 flow metrics to assess streamflow alteration at 129 selected streamgages in Kansas are presented in this section. The order of presentation is mean monthly flows, annual low-flow metrics, annual high-flow metrics, and other annual flow metrics. In the results presented, a minimally altered condition indicates that the $\mathrm{O} / \mathrm{E}$ value for the flow metric is within the model error and is considered least disturbed. A diminished condition indicates that the $\mathrm{O} / \mathrm{E}$ value for the flow metric is less than what would be expected for a least-disturbed condition. An inflated condition indicates that the $\mathrm{O} / \mathrm{E}$ value for the flow metric is greater than what would be expected for a least-disturbed condition. Complete $\mathrm{O} / \mathrm{E}$ results for all streamgages are provided in tables $1-1$ to $1-8$ in the appendix at the back of this report.

\section{Mean Monthly Flows}

In Kansas, a minimally altered condition for mean monthly flow was indicated for every month for the majority of the streamgages. The percentage of streamgages with a minimally altered condition ranged from 59 percent for March and December to 81 percent for July, with an all-month average of 66 percent (table 4). A diminished condition for mean monthly flow was indicated for a substantial number of streamgages, ranging from 14 percent for August to 39 percent for March, with an all-month average of 28 percent. With one exception, streamgages with an inflated condition for mean monthly flow were uncommon. The exception was August for which 24 percent of the streamgages had an inflated condition. For most months, the percentage of streamgages with an inflated condition was 5 percent or less.

Geographically, a pronounced pattern was evident for the distribution of streamgages with a diminished condition for mean monthly flows. In general, such streamgages were in the western half of Kansas (figs. 3-14, at the back of this report). Twelve streamgages in western Kansas (sites 4, 6, 9, 12-15, $29,88,90,107$, and 110) had a diminished condition for all 12 months (figs. 3-14; tables $1-1$ to $1-3$ in the appendix). Major river basins in western Kansas with diminished flows for multiple months and multiple streamgages were the Arkansas, Cimarron, Republican, Saline, Smoky Hill, and Solomon (figs. 3-14).

\section{Annual Low-Flow Metrics}

Annual low-flow metrics assessed were the average number, duration, and magnitude of flow pulses less than the 10th and 25 th percentiles. For average duration and magnitude, the assessment was limited for western Kansas because it was not possible to compute those two metrics for several streamgages given an absence of flow.

Alteration of flow pulses less than the 10th percentile was evident across the State. For the average annual number of such pulses, the indicated conditions were minimally altered for 41 percent, diminished for 22 percent, and inflated for 36 percent of the streamgages (table 5). Reductions in the number of such pulses typically were for streamgages in the western half of Kansas, whereas increases typically were for streamgages in central and eastern Kansas (fig. 15, at the back 
Table 3. Model performance criteria.

[Bias, percent bias (unstandardized values); $\mathrm{O} / \mathrm{E}$, observed $(\mathrm{O})$ divided by expected (E) values (that is, $\mathrm{O} / \mathrm{E}$ ratio; unstandardized values); SD, standard deviation; NSE, Nash-Sutcliffe efficiency (unstandardized values); Comp, composite performance criterion ( 0 to 4 , higher score

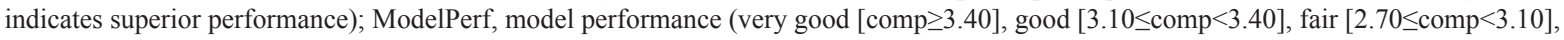
and poor $[$ comp $<2.70])]$

\begin{tabular}{|c|c|c|c|c|c|c|}
\hline Metric (table 1) & Bias $^{a}$ & Mean 0/E & SD 0/E & NSE $^{\mathrm{c}}$ & Comp & ModeIPerf ${ }^{d}$ \\
\hline P50 & 0.37 & 0.92 & 0.43 & 0.93 & 3.419 & Very good. \\
\hline CV_FLOW & -0.58 & 0.99 & 0.23 & 0.78 & 3.531 & Very good. \\
\hline AVG_JAN & -1.06 & 0.95 & 0.48 & 0.96 & 3.413 & Very good. \\
\hline AVG_FEB & -0.53 & 0.96 & 0.45 & 0.95 & 3.46 & Very good. \\
\hline AVG_MAR & -0.6 & 0.97 & 0.56 & 0.94 & 3.356 & Good. \\
\hline AVG_APR & -1.31 & 0.95 & 0.35 & 0.93 & 3.512 & Very good. \\
\hline AVG_MAY & -1.49 & 0.95 & 0.39 & 0.87 & 3.409 & Very good. \\
\hline AVG_JUN & -1.26 & 0.95 & 0.44 & 0.88 & 3.385 & Good. \\
\hline AVG_JUL & 1.51 & 0.96 & 0.47 & 0.87 & 3.355 & Good. \\
\hline AVG_AUG & 3.45 & 0.97 & 0.53 & 0.8 & 3.202 & Good. \\
\hline AVG_SEP & 2.52 & 0.97 & 0.55 & 0.79 & 3.18 & Good. \\
\hline AVG_OCT & 0.93 & 0.97 & 0.48 & 0.88 & 3.362 & Good. \\
\hline AVG_NOV & -0.42 & 0.94 & 0.43 & 0.95 & 3.459 & Very good. \\
\hline AVG_DEC & -1.37 & 0.94 & 0.46 & 0.95 & 3.417 & Very good \\
\hline PUL_NO_P90 & 0.25 & 0.98 & 0.26 & 0.82 & 3.54 & Very good. \\
\hline PUL_NO_P75 & 0.43 & 0.98 & 0.26 & 0.81 & 3.529 & Very good. \\
\hline PUL_NO_P25 & 2.22 & 1.01 & 0.55 & 0.57 & 2.985 & Fair. \\
\hline PUL_NO_P10 & 0.77 & 1.01 & 0.8 & 0.54 & 2.712 & Fair. \\
\hline $\mathrm{P} 10$ & 2.15 & 0.87 & 0.63 & 0.77 & 2.997 & Fair. \\
\hline P90 & -1.59 & 0.94 & 0.32 & 0.94 & 3.55 & Very good. \\
\hline PER_BSFL & -5.96 & 0.89 & 0.85 & 0.07 & 2.051 & Poor. \\
\hline PUL_LEN_P10 & -3.03 & 0.96 & 0.38 & 0.45 & 3 & Fair. \\
\hline PUL_LEN_P25 & -4.85 & 0.95 & 0.35 & 0.49 & 3.049 & Fair. \\
\hline PUL_LEN_P75 & -3.04 & 0.96 & 0.36 & 0.69 & 3.269 & Good. \\
\hline PUL_LEN_P90 & -2.79 & 0.96 & 0.36 & 0.72 & 3.293 & Good. \\
\hline PUL_FLOW_P10 & 2.04 & 0.85 & 0.63 & 0.76 & 2.964 & Fair. \\
\hline PUL_FLOW_P25 & 2.39 & 0.89 & 0.58 & 0.8 & 3.09 & Fair. \\
\hline PUL_FLOW_P75 & -1.17 & 0.97 & 0.33 & 0.94 & 3.572 & Very good. \\
\hline PUL_FLOW_P90 & -1.22 & 0.97 & 0.33 & 0.94 & 3.573 & Very good. \\
\hline
\end{tabular}

of this report). For the average duration of such pulses, the indicated conditions were minimally altered for 47 percent, diminished for 26 percent, inflated for 5 percent, and not computed for 22 percent of the streamgages (table 5). For the average magnitude of such pulses, the indicated conditions were minimally altered for 43 percent, diminished for 16 percent, inflated for 19 percent, and not computed for 22 percent of the streamgages. A pronounced statewide pattern for the distribution of streamgages with a diminished or inflated condition for the average duration and magnitude of flow pulses less than the 10th percentile was not apparent (figs. 16 and 17, at the back of this report). Although, a diminished condition for average duration was indicated for a cluster of 13 streamgages in extreme east-central Kansas (fig. 16). 
Table 4. Summary of alteration of mean monthly flows for 129 streamgages in Kansas.

$[\%$, percent rounded to nearest whole number. As a result of rounding error, the percentages for a given month may not sum to 100]

\begin{tabular}{lccc}
\hline \multirow{2}{*}{ Month } & \multicolumn{3}{c}{ Number of streamgages } \\
\cline { 2 - 4 } & $\begin{array}{c}\text { Diminished } \\
\text { condition }\end{array}$ & $\begin{array}{c}\text { Minimally } \\
\text { altered } \\
\text { condition }\end{array}$ & $\begin{array}{c}\text { Inflated } \\
\text { condition }\end{array}$ \\
\hline January & $44(34 \%)$ & $80(62 \%)$ & $5(4 \%)$ \\
February & $37(29 \%)$ & $89(69 \%)$ & $3(2 \%)$ \\
March & $50(39 \%)$ & $76(59 \%)$ & $3(2 \%)$ \\
April & $37(29 \%)$ & $83(64 \%)$ & $9(7 \%)$ \\
May & $35(27 \%)$ & $88(68 \%)$ & $6(5 \%)$ \\
June & $39(30 \%)$ & $83(64 \%)$ & $7(5 \%)$ \\
July & $19(15 \%)$ & $104(81 \%)$ & $6(5 \%)$ \\
August & $18(14 \%)$ & $80(62 \%)$ & $31(24 \%)$ \\
September & $39(30 \%)$ & $84(65 \%)$ & $6(5 \%)$ \\
October & $38(29 \%)$ & $88(68 \%)$ & $3(2 \%)$ \\
November & $39(30 \%)$ & $86(67 \%)$ & $4(3 \%)$ \\
December & $40(31 \%)$ & $76(59 \%)$ & $13(10 \%)$ \\
12-month mean & $36(28 \%)$ & $85(66 \%)$ & $8(6 \%)$ \\
\hline
\end{tabular}

Alteration of flow pulses less than the 25th percentile was less evident. For the average annual number of such pulses, a minimally altered condition was indicated for 74 percent of the streamgages. The remaining 26 percent was split equally between streamgages with a diminished and an inflated condition (table 5). Streamgages with a decreased number of such pulses typically were in the western half of Kansas (fig. 18, at the back of this report). For the average duration and average magnitude of pulses less than the 25th percentile, similar conditions were indicated, as follows: minimally altered, mean of 61.5 percent; diminished, mean of 13 percent; inflated, mean of 12.5 percent; and not computed, 13 percent (table 5). The locations of streamgages with a diminished, inflated, or minimally altered condition for the duration and magnitude of flow pulses less than the 25th percentile are provided in figures 19 and 20 , at the back of this report.

\section{Annual High-Flow Metrics}

Annual high-flow metrics assessed were the average number, duration, and magnitude of flow pulses greater than the 75th and 90th percentiles. In Kansas, there was considerable alteration of flow pulses greater than both percentiles.

For the average annual number of pulses greater than the 75th percentile, a diminished condition was indicated for 26 percent of the streamgages, most of which were in the western half of Kansas. Conversely, an inflated condition was indicated for 25 percent of the streamgages, most of which were in the eastern half of Kansas (fig. 21, at the back of this report; table 6). For the remaining streamgages, a minimally altered condition was indicated.

The average duration of flow pulses greater than the 75 th percentile was minimally altered for 71 percent of the streamgages. An inflated and diminished condition was indicated for 23 percent and 6 percent of the streamgages, respectively (table 6). Frequently, especially in western Kansas, streamgages with an inflated condition for average duration also had a diminished condition for the average annual number of flow pulses greater than the 75th percentile (figs. 21 and 22 , at the back of this report). Thus, at those sites, such flow pulses occurred less often but lasted longer compared with what would be expected for a least-disturbed condition.

Table 5. Summary of alteration of annual low-flow metrics for 129 streamgages in Kansas.

$[\%$, percent rounded to nearest whole number. As a result of rounding error, the percentages for a given flow metric may not sum to 100 . na, not applicable]

\begin{tabular}{lcccc}
\hline \multirow{2}{*}{ Metric (table 1) } & \multicolumn{4}{c}{ Number of streamgages } \\
\cline { 2 - 5 } & $\begin{array}{c}\text { Diminished } \\
\text { condition }\end{array}$ & $\begin{array}{c}\text { Minimally altered } \\
\text { condition }\end{array}$ & $\begin{array}{c}\text { Inflated } \\
\text { condition }\end{array}$ & $\begin{array}{c}\text { Not } \\
\text { computed }\end{array}$ \\
\hline PUL_NO_P10 & $29(22 \%)$ & $53(41 \%)$ & $47(36 \%)$ & na \\
PUL_LEN_P10 & $33(26 \%)$ & $60(47 \%)$ & $7(5 \%)$ & $29(22 \%)$ \\
PUL_FLOW_P10 & $20(16 \%)$ & $56(43 \%)$ & $24(19 \%)$ & $29(22 \%)$ \\
PUL_NO_P25 & $17(13 \%)$ & $95(74 \%)$ & $17(13 \%)$ & na \\
PUL_LEN_P25 & $18(14 \%)$ & $79(61 \%)$ & $15(12 \%)$ & $17(13 \%)$ \\
PUL_FLOW_P25 & $15(12 \%)$ & $80(62 \%)$ & $17(13 \%)$ & $17(13 \%)$ \\
\hline
\end{tabular}

${ }^{\mathrm{a}}$ Average annual number of flow pulses less than the 10th percentile.

${ }^{\mathrm{b}}$ Average duration of flow pulses less than the 10th percentile.

cAverage magnitude of flow pulses less than the 10th percentile, normalized by drainage area.

dAverage annual number of flow pulses less than the 25th percentile.

${ }^{\mathrm{e}}$ Average duration of flow pulses less than the 25th percentile.

${ }^{\mathrm{f}}$ Average magnitude of flow pulses less than the 25 th percentile, normalized by drainage area. 
Table 6. Summary of alteration of annual high-flow metrics for 129 streamgages in Kansas.

$[\%$, percent rounded to nearest whole number. As a result of rounding error, the percentages for a given flow metric may not sum to 100]

\begin{tabular}{lccc}
\hline & \multicolumn{3}{c}{ Number of streamgages } \\
\cline { 2 - 4 } Metric (table 1) & $\begin{array}{c}\text { Diminished } \\
\text { condition }\end{array}$ & $\begin{array}{c}\text { Minimally } \\
\text { altered } \\
\text { condition }\end{array}$ & $\begin{array}{c}\text { Inflated } \\
\text { condition }\end{array}$ \\
\hline PUL_NO_P75 & $33(26 \%)$ & $64(50 \%)$ & $32(25 \%)$ \\
PUL_LEN_P75 & $8(6 \%)$ & $91(71 \%)$ & $30(23 \%)$ \\
PUL_FLOW_P75 & $48(37 \%)$ & $79(61 \%)$ & $2(2 \%)$ \\
PUL_NO_P90 & $45(35 \%)$ & $62(48 \%)$ & $22(17 \%)$ \\
PUL_LEN_P90 & $75(58 \%)$ & $46(36 \%)$ & $8(6 \%)$ \\
PUL_FLOW_P90 & $52(40 \%)$ & $75(58 \%)$ & $2(2 \%)$ \\
\hline
\end{tabular}

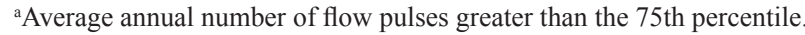

${ }^{\mathrm{b}}$ Average duration of flow pulses greater than the 75 th percentile.

${ }^{\mathrm{c}}$ Average magnitude of flow pulses greater than the 75 th percentile, normalized by drainage area.

${ }^{\mathrm{d}}$ Average annual number of flow pulses greater than the 90th percentile.

${ }^{\mathrm{e}}$ Average duration of flow pulses greater than the 90th percentile.

${ }^{\mathrm{f}}$ Average magnitude of flow pulses greater than the 90th percentile, normalized by drainage area.

The average magnitude of flow pulses greater than the 75th percentile was minimally altered for 61 percent of the streamgages. A diminished condition was indicated for 37 percent of the streamgages (table 6). Most of the streamgages with a diminished condition were in the western half of Kansas (fig. 23, at the back of this report). An inflated condition was indicated for the remaining 2 percent of the streamgages (table 6).

Considerable alteration also was evident for flow pulses greater than the 90th percentile. For the average annual number of such pulses, streamgages with a minimally altered, diminished, and inflated condition accounted for 48,35 , and 17 percent, respectively (fig. 24, at the back of this report; table 6). For the average duration of such pulses, streamgages with a minimally altered, diminished, and inflated condition accounted for 36, 58, and 6 percent, respectively (fig. 25, at the back of this report; table 6). For the average magnitude of such pulses, the indicated conditions were minimally altered, 58 percent; diminished, 40 percent; and inflated, 2 percent (table 6). Most of the streamgages with a diminished condition for average magnitude were in the western half of Kansas (fig. 26, at the back of this report).

\section{Other Annual Flow Metrics}

Five additional annual flow metrics that were assessed were percentage of flow that is base flow, 10th percentile flow normalized by drainage area, median flow normalized by drainage area, 90th percentile flow normalized by drainage area, and coefficient of variation of daily flows. For the percentage of flow that is base flow, a minimally altered condition was indicated for 81 percent of the streamgages (fig. 27, at the back of this report; table 7). Indicated conditions for the 10th percentile flow were minimally altered, 72 percent of streamgages; diminished, 12 percent; and inflated, 16 percent (table 7). For median flow, the indicated conditions were minimally altered, 73 percent; diminished, 20 percent; and inflated, 7 percent. Streamgages with a diminished condition for 10th percentile and median flow typically were in the western half of Kansas (figs. 28 and 29, at the back of this report). Throughout the State, 90th percentile flow typically was decreased as evidenced by a diminished condition that was indicated for 81 percent of the streamgages (fig. 30, at the back of this report; table 7). For the coefficient of variation of daily flows, a minimally altered condition was indicated for 73 percent of the streamgages (fig. 31, at the back of this report; table 7).

Table 7. Summary of alteration of other annual flow metrics for 129 streamgages in Kansas.

$[\%$, percent rounded to nearest whole number. As a result of rounding error, the percentages for a given flow metric may not sum to 100]

\begin{tabular}{|c|c|c|c|}
\hline \multirow[b]{2}{*}{ Metric (table 1) } & \multicolumn{3}{|c|}{ Number of streamgages } \\
\hline & $\begin{array}{l}\text { Diminished } \\
\text { condition }\end{array}$ & $\begin{array}{l}\text { Minimally } \\
\text { altered } \\
\text { condition }\end{array}$ & $\begin{array}{l}\text { Inflated } \\
\text { condition }\end{array}$ \\
\hline PER_BSFL ${ }^{a}$ & $11(9 \%)$ & $105(81 \%)$ & $13(10 \%)$ \\
\hline $\mathrm{P} 10^{\mathrm{b}}$ & $15(12 \%)$ & $93(72 \%)$ & $21(16 \%)$ \\
\hline $\mathrm{P} 50^{\mathrm{c}}$ & $26(20 \%)$ & $94(73 \%)$ & $9(7 \%)$ \\
\hline $\mathrm{P} 90^{\mathrm{d}}$ & $104(81 \%)$ & $25(19 \%)$ & $0(0 \%)$ \\
\hline CV_FLOWe & $20(16 \%)$ & $94(73 \%)$ & $15(12 \%)$ \\
\hline \multicolumn{4}{|c|}{ 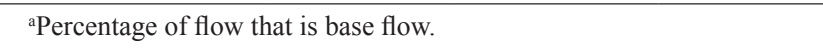 } \\
\hline \multicolumn{4}{|c|}{${ }^{\mathrm{b}}$ Tenth percentile flow normalized by drainage area. } \\
\hline \multicolumn{4}{|c|}{ 'Median annual flow normalized by drainage area. } \\
\hline \multicolumn{4}{|c|}{ `Ninetieth percentile flow normalized by drainage area. } \\
\hline${ }^{\mathrm{e}}$ Coefficient of varis & (1) & & \\
\hline
\end{tabular}

\section{Effects of Human Disturbances on Streamflow and Habitat Implications}

Human disturbances that have altered streamflow in Kansas can be categorized as regional and local. Regional disturbances include groundwater pumping from the High Plains aquifer and agricultural land-management practices. Local disturbances include reservoirs and urbanization. In the following sections, streamflow alteration in response to each of these disturbances is discussed and the possible habitat implications are briefly described. 


\section{Groundwater Pumping from the High Plains Aquifer}

Groundwater withdrawals can cause groundwater-level declines and decreased groundwater contributions to streams, which can result in a reduction of streamflow (Winter, 2007; Barlow and Leake, 2012). Long-term and extensive pumping from the High Plains aquifer for irrigation is the primary cause of substantial groundwater-level declines in parts of western and central Kansas (Gutentag and others, 1984; Young and others, 2005; Whittemore and others, 2016) (fig. 2).

Groundwater pumping from the High Plains aquifer likely was responsible, in part, for the regional pattern of diminished streamflow conditions indicated for western and central Kansas. Support for this statement is twofold. First, the geographic distribution of streamgages with a diminished condition for multiple flow metrics generally corresponded with the area underlain by the High Plains aquifer and adjacent downstream areas (for example, see figs. 3, 7, 20, and 29). Second, there was no pronounced decreasing trend in annual precipitation (see the "Description of Kansas" section) that could account for the regional pattern of diminished streamflow conditions in western and central Kansas. A decreasing streamflow trend for several western Kansas streams has been documented (Rasmussen and Perry, 2001; Dodds and others, 2004; Gido and others, 2010; Juracek, 2015).

\section{Agricultural Land-Management Practices}

Historically, agricultural land-management practices have had a pronounced effect on streamflow. In response to the initial conversion of grassland and forest to cropland, infiltration decreased and surface runoff increased, resulting in an increased magnitude of high flows (Knox, 2001). Subsequently, as land-management practices improved in response to the need to decrease soil erosion and loss, infiltration increased and surface runoff decreased, resulting in increased base flow and a decreased magnitude of high flows (Potter, 1991; Gebert and Krug, 1996; Kramer and others, 1999; Knox, 2001). Included among the practices implemented to decrease runoff and increase infiltration were terraces, contour plowing, and conservation tillage (Zhang and Schilling, 2006; Juckem and others, 2008).

In Kansas, agricultural land-management practices likely have affected streamflows. In a study of rainfall-runoff relations, Jordan (1982) cited farm ponds, terraces, and changes in tillage methods as likely contributing factors for decreases in streamflow in several western Kansas streams. More recently, Putnam and others (2008) cited practices such as contour plowing and terraces as possible contributing factors for a progressive decrease in the runoff-to-precipitation ratio during historical droughts in the State. The effect of changing landmanagement practices possibly was indicated by several flow metrics. Case in point, for a number of streamgages in central and eastern Kansas, an inflated condition was indicated for the average magnitude of flow pulses less than the 10th percentile (fig. 17). The inflated condition for this metric may, in part, be attributable to increased base flow. A diminished condition for the average duration of flow pulses greater than the 90th percentile (fig. 25) and the magnitude of 90th percentile flow (fig. 30) was indicated for the majority of streamgages statewide. The diminished condition for these two metrics may, in part, be attributable to increased infiltration and decreased surface runoff associated with the implementation of improved land-management practices.

\section{Reservoirs}

A large reservoir can substantially alter the natural flow regime downstream from the dam. Typically, the magnitude of peak flows is reduced (Graf, 2006). Other possible downstream changes include an increase or decrease in the magnitude of low flows, an artificial flow regime characterized by abrupt increases and decreases in flow, a change in the temporal distribution of flows, and extended periods of no flow (Williams and Wolman, 1984; Kondolf, 1997; Magilligan and Nislow, 2005).

In this study, streamflow alteration downstream from 20 large reservoirs in Kansas was assessed using the first streamgage downstream from each dam (fig. 32). The assessment revealed pronounced differences in downstream flow alteration between reservoirs in western and eastern Kansas. Thus, for the purpose of discussion, the reservoirs were split into a western group (consisting of 8 reservoirs) and an eastern group (consisting of 12 reservoirs) (fig. 32).

In general, mean monthly flows downstream from the 8 western reservoirs were diminished, whereas such flows were minimally altered downstream from the 12 eastern reservoirs. For the western reservoirs, the percentage of downstream streamgages with a diminished condition ranged from 37 percent for July and August to 100 percent for March, with an all-month average of 68 percent. Conversely, for the eastern reservoirs, the percentage of downstream streamgages that were minimally altered ranged from 58 percent for September to 100 percent for four different months, with an all-month average of 86 percent (table 8 ).

Comparison of the western and eastern reservoirs using the annual low-flow metrics was constrained as the average duration and magnitude of low-flow pulses could not be computed downstream from several western reservoirs because of an absence of flow. For the eastern reservoirs, a minimally altered condition typically was indicated for the downstream streamgages for the average magnitude of pulses less than the 10 th percentile (67 percent of streamgages). Likewise, for flow pulses less than the 25 th percentile, a minimally altered condition typically was indicated for the average number ( 83 percent), average duration (67 percent), and average magnitude (75 percent). For the average duration of flow pulses less than the 10 th percentile, a diminished condition typically (67 percent) was indicated for the eastern reservoirs (table 8). 
Table 8. Summary of streamflow alteration downstream from 20 large reservoirs in Kansas.

[\%, percent rounded to nearest whole number. As a result of rounding error, the percentages for a given flow metric may not sum to 100]

\begin{tabular}{|c|c|c|c|c|c|c|}
\hline \multirow{2}{*}{ Metric (table 1) } & \multicolumn{3}{|c|}{$\begin{array}{c}\text { Streamgages downstream from eight western } \\
\text { Kansas reservoirs (fig. 32) }\end{array}$} & \multicolumn{3}{|c|}{$\begin{array}{c}\text { Streamgages downstream from twelve eastern } \\
\text { Kansas reservoirs (fig. 32) }\end{array}$} \\
\hline & $\begin{array}{l}\text { Diminished } \\
\text { condition }\end{array}$ & $\begin{array}{l}\text { Minimally } \\
\text { altered condition }\end{array}$ & $\begin{array}{l}\text { Inflated } \\
\text { condition }\end{array}$ & $\begin{array}{l}\text { Diminished } \\
\text { condition }\end{array}$ & $\begin{array}{l}\text { Minimally } \\
\text { altered condition }\end{array}$ & $\begin{array}{l}\text { Inflated } \\
\text { condition }\end{array}$ \\
\hline AVG_JAN & $6(75 \%)$ & $2(25 \%)$ & $0(0 \%)$ & $1(8 \%)$ & $10(83 \%)$ & $1(8 \%)$ \\
\hline AVG_FEB & $7(88 \%)$ & $1(12 \%)$ & $0(0 \%)$ & $0(0 \%)$ & $12(100 \%)$ & $0(0 \%)$ \\
\hline AVG_MAR & $8(100 \%)$ & $0(0 \%)$ & $0(0 \%)$ & $3(25 \%)$ & $9(75 \%)$ & $0(0 \%)$ \\
\hline AVG_APR & $6(75 \%)$ & $2(25 \%)$ & $0(0 \%)$ & $1(8 \%)$ & $11(92 \%)$ & $0(0 \%)$ \\
\hline AVG_MAY & $7(88 \%)$ & $1(12 \%)$ & $0(0 \%)$ & $0(0 \%)$ & $12(100 \%)$ & $0(0 \%)$ \\
\hline AVG_JUN & $7(88 \%)$ & $1(12 \%)$ & $0(0 \%)$ & $0(0 \%)$ & $11(92 \%)$ & $1(8 \%)$ \\
\hline AVG_JUL & $3(37 \%)$ & $5(63 \%)$ & $0(0 \%)$ & $0(0 \%)$ & $11(92 \%)$ & $1(8 \%)$ \\
\hline AVG_AUG & $3(37 \%)$ & $3(37 \%)$ & $2(25 \%)$ & $0(0 \%)$ & $8(67 \%)$ & $4(33 \%)$ \\
\hline AVG_SEP & $4(50 \%)$ & $4(50 \%)$ & $0(0 \%)$ & $5(42 \%)$ & $7(58 \%)$ & $0(0 \%)$ \\
\hline AVG_OCT & $5(63 \%)$ & $3(37 \%)$ & $0(0 \%)$ & $0(0 \%)$ & $12(100 \%)$ & $0(0 \%)$ \\
\hline AVG_NOV & $5(63 \%)$ & $3(37 \%)$ & $0(0 \%)$ & $0(0 \%)$ & $12(100 \%)$ & $0(0 \%)$ \\
\hline AVG_DEC & $4(50 \%)$ & $4(50 \%)$ & $0(0 \%)$ & $1(8 \%)$ & $8(67 \%)$ & $3(25 \%)$ \\
\hline PUL_NO_P10 & $4(50 \%)$ & $1(12 \%)$ & $3(37 \%)$ & $1(8 \%)$ & $4(33 \%)$ & $7(58 \%)$ \\
\hline PUL_LEN_P10 ${ }^{\mathrm{a}}$ & $1(12 \%)$ & $2(25 \%)$ & $1(12 \%)$ & $8(67 \%)$ & $3(25 \%)$ & $0(0 \%)$ \\
\hline PUL_FLOW_P10 & $1(12 \%)$ & $3(37 \%)$ & $0(0 \%)$ & $1(8 \%)$ & $8(67 \%)$ & $2(17 \%)$ \\
\hline PUL_NO_P25 & $2(25 \%)$ & $5(63 \%)$ & $1(12 \%)$ & $0(0 \%)$ & $10(83 \%)$ & $2(17 \%)$ \\
\hline PUL_LEN_P25 & $1(12 \%)$ & $3(37 \%)$ & $2(25 \%)$ & $3(25 \%)$ & $8(67 \%)$ & $1(8 \%)$ \\
\hline PUL_FLOW_P25a & $3(37 \%)$ & $2(25 \%)$ & $1(12 \%)$ & $2(17 \%)$ & $9(75 \%)$ & $1(8 \%)$ \\
\hline PUL_NO_P75 & $6(75 \%)$ & $1(12 \%)$ & $1(12 \%)$ & $3(25 \%)$ & $8(67 \%)$ & $1(8 \%)$ \\
\hline PUL_LEN_P75 & $2(25 \%)$ & $1(12 \%)$ & $5(63 \%)$ & $0(0 \%)$ & $5(42 \%)$ & $7(58 \%)$ \\
\hline PUL_FLOW_P75 & $7(88 \%)$ & $1(12 \%)$ & $0(0 \%)$ & $0(0 \%)$ & $12(100 \%)$ & $0(0 \%)$ \\
\hline PUL_NO_P90 & $7(88 \%)$ & $1(12 \%)$ & $0(0 \%)$ & $8(67 \%)$ & $4(33 \%)$ & $0(0 \%)$ \\
\hline PUL_LEN_P90 & $1(12 \%)$ & $4(50 \%)$ & $3(37 \%)$ & $0(0 \%)$ & $9(75 \%)$ & $3(25 \%)$ \\
\hline PUL_FLOW_P90 & $7(88 \%)$ & $1(12 \%)$ & $0(0 \%)$ & $1(8 \%)$ & $11(92 \%)$ & $0(0 \%)$ \\
\hline PER_BSFL & $0(0 \%)$ & $8(100 \%)$ & $0(0 \%)$ & $0(0 \%)$ & $10(83 \%)$ & $2(17 \%)$ \\
\hline P10 & $4(50 \%)$ & $3(37 \%)$ & $1(12 \%)$ & $2(17 \%)$ & $9(75 \%)$ & $1(8 \%)$ \\
\hline P50 & $5(63 \%)$ & $3(37 \%)$ & $0(0 \%)$ & $1(8 \%)$ & $11(92 \%)$ & $0(0 \%)$ \\
\hline P90 & $8(100 \%)$ & $0(0 \%)$ & $0(0 \%)$ & $3(25 \%)$ & $9(75 \%)$ & $0(0 \%)$ \\
\hline CV_FLOW & $0(0 \%)$ & $4(50 \%)$ & $4(50 \%)$ & $0(0 \%)$ & 11 (92\%) & $1(8 \%)$ \\
\hline
\end{tabular}

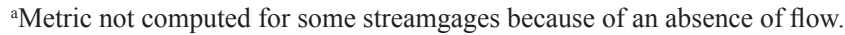




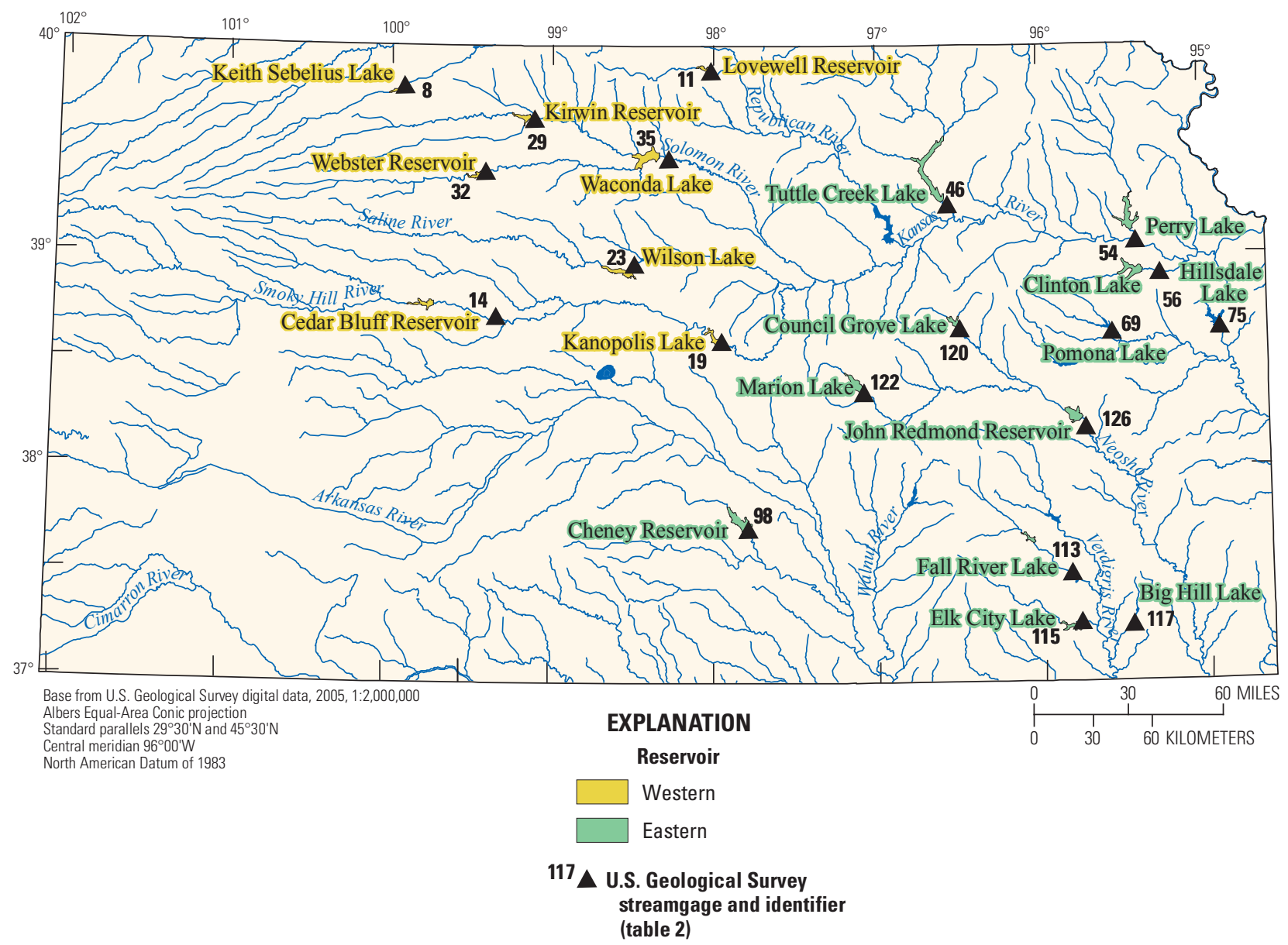

Figure 32. Large reservoirs and selected U.S. Geological Survey streamgages in Kansas.

For the annual high-flow metrics, a comparison of the western and eastern reservoirs revealed similarities and differences. In terms of the average number of flow pulses greater than the 75th percentile, a diminished condition typically (75 percent) was indicated for streamgages downstream from the western reservoirs, whereas a minimally altered condition typically (67 percent) was indicated for streamgages downstream from the eastern reservoirs. For the average duration of such pulses, an inflated condition was indicated for the majority of streamgages downstream from the western and eastern reservoirs (63 percent and 58 percent, respectively). The increased duration may be reflective of reservoir operational practices intended to manage downstream flood risk by releasing high flows over an extended period of time. The average magnitude of flow pulses greater than the 75 th percentile was minimally altered for the eastern reservoirs (100 percent of downstream streamgages) and typically diminished for the western reservoirs (88 percent of downstream streamgages) (table 8).

Flow pulses greater than the 90th percentile were similar for the western and eastern reservoirs in terms of the average number and duration of pulses but divergent for the average magnitude. For the average number of such pulses, a diminished condition typically (88 and 67 percent, respectively) was indicated for streamgages downstream from the western and eastern reservoirs. For the average duration, the indicated condition for both the western and eastern reservoirs typically was either minimally altered (largest percentage of downstream streamgages) or inflated. The average magnitude of flow pulses greater than the 90th percentile typically was minimally altered (92 percent) for streamgages downstream from the eastern reservoirs and typically diminished ( 88 percent) for streamgages downstream from the western reservoirs (table 8).

A minimally altered condition typically was indicated for the streamgages downstream from the eastern reservoirs for the base flow, 10th percentile flow, median flow, 90th percentile flow, and coefficient of variation annual metrics (table 8). For the western reservoirs, streamflow alteration was apparent. Of particular note was the diminished condition indicated for annual median flow (63 percent of downstream streamgages) and annual 90th percentile flow (100 percent) (table 8).

Overall, the assessment of streamflow alteration downstream from the 20 large reservoirs indicated a diminished condition for the 8 western reservoirs and a minimally altered condition for the 12 eastern reservoirs. At least two factors may, in part, account for the diminished condition downstream from the western reservoirs. One factor is diversion of water for irrigation and (or) municipal use at and (or) upstream from 
the reservoirs. A second factor is reservoir operational practices (for example, suppression of high flows by controlled releases).

\section{Urbanization}

The effects of urbanization on streamflow can be pronounced. In general, the increased percentage of impervious surfaces and more efficient drainage systems characteristic of urban areas result in an increased volume of runoff for a given rainfall and a flashier flow regime typified by shorter lag times and more frequent and higher peak discharges (Knighton, 1998; Rose and Peters, 2001). Heterogeneity in hydrologic response to urbanization also has been documented. For example, in a study of hydrological changes associated with urbanization in nine major cities in the United States, Hopkins and others (2015) determined that hydrologic response in similarly urbanized areas varied in relation to basin physical characteristics. Specifically, they found that urbanized basins with level slopes and high soil permeability, compared to similarly urbanized basins with steep slopes and low soil permeability, had fewer high-flow events, lower peak magnitudes, longer high-flow durations, and a less flashy flow regime.

Of all the streamgages included in this streamflow alteration study, only three were within basins that were predominantly urbanized. The three streamgages, all in the Kansas City metropolitan area in Johnson County, Kansas, were site 60 (about 70 percent urban) and sites 63 and 64 (both nearly 100 percent urban; fig. 1; Peterson and others, 2010). Site 60 is on Mill Creek and sites 63 and 64 are along Indian Creek.

Streamflow alteration, when indicated, was consistent among the three urbanized sites. The alteration included an inflated condition for mean monthly flows, especially for sites 63 and 64 (tables 1-1 to 1-3). For these two sites, an inflated condition was indicated for at least one and typically both of the sites for all 12 months. The inflated condition at these two sites may, in part, be attributable to discharges from municipal wastewater treatment facilities (Rasmussen and Gatotho, 2014) as well as other possible factors, including leaky infrastructure (for example, water-supply and sewage pipes; Bhaskar and others, 2016).

Flow pulses were substantially altered. For flow pulses less than the 10th and 25th percentiles, an inflated condition was indicated for the average number and average magnitude and a diminished condition was indicated for the average duration for all three sites (tables 1-4 and 1-5). Likewise, for flow pulses greater than the 75th and 90th percentiles, an inflated condition was indicated for the average number and a diminished condition was indicated for the average duration for all three sites (tables 1-6 and 1-7). However, an inflated condition for the average magnitude was only indicated for sites 63 and 64. Overall, a flashier flow regime was indicated for the three urbanized sites compared with what would be expected for a least-disturbed condition. Other changes indicated for all three sites were an inflated condition for the 10th percentile flow and median flow and a diminished condition for the coefficient of variation of daily flows (table 1-8).

\section{Habitat Implications}

A natural flow regime is essential to provide the diversity of habitat conditions necessary to maintain the ecological integrity of streams (Poff and others, 1997; Bunn and Arthington, 2002). Alteration of the natural flow regime can have adverse consequences for resident aquatic organisms. For example, in an extensive review of flow alteration and ecological response, Poff and Zimmerman (2010) determined that fish abundance and diversity consistently decreased in response to flow alteration (both increased and decreased flow magnitude) and the risk of ecological change increased as the magnitude of flow alteration increased. In a study of about 250 sites throughout the conterminous United States, Carlisle and others (2011) concluded that the likelihood of impairment for fish and macroinvertebrate communities doubled with increasing severity of reduced minimum and maximum flows.

For Kansas, the evidence provided by this study indicated that multiple human disturbances, singly and in combination, have caused widespread streamflow alteration. In general, streamflow alteration has negative ecological effects, including a loss of habitat and (or) a decline in the quality of available habitat. Possible consequences of lost and degraded habitat include a loss of native species, an increase in nonnative species, and a less diverse assemblage of aquatic biota dominated by disturbance-tolerant species (Walsh and others, 2005; Gido and others, 2010; Hoagstrom and others, 2011; Perkin and others, 2015). For the State-listed threatened Arkansas darter (Etheostoma cragini) (Haslouer and others, 2005), streamflow alteration, in particular flow depletion, likely has adversely affected the availability and quality of habitat in the State (Juracek and others, 2017).

\section{Summary and Conclusions}

A 1.5-year modeling study by the U.S. Geological Survey, in cooperation with the Kansas Department of Wildlife, Parks and Tourism and the U.S. Fish and Wildlife Service, was begun in 2016 to assess streamflow alteration at 129 selected U.S. Geological Survey streamgage sites in Kansas for which requisite streamflow and basin-characteristic information was available. The purpose of the assessment was to quantify and explain streamflow alteration through a comparison of the observed condition (1980 to 2015) with the predicted expected (least-disturbed) condition using 29 metrics that accounted for various aspects of streamflow. For each metric at each streamgage, the determined condition was characterized as diminished, minimally altered, or inflated. Results of the assessment are summarized below: 
- For mean monthly streamflow, a minimally altered condition was indicated for an average of 66 percent of the streamgages for every month. On average, a diminished condition was indicated for 28 percent of the streamgages each month. Typically, streamgages with a diminished condition for mean monthly flow were in the western half of Kansas.

- Alteration of the average annual number, duration, and magnitude of flow pulses less than the 10th percentile was evident statewide. For the average annual number of such pulses, streamgages with a diminished condition typically were in the western half of Kansas and streamgages with an inflated condition typically were in central and eastern Kansas.

- For the average annual number, duration, and magnitude of flow pulses less than the 25th percentile, a minimally altered condition typically was indicated. Streamgages with a diminished condition for the average annual number of such pulses typically were in the western half of Kansas.

- Pronounced alteration was indicated for flow pulses greater than the 75 th percentile. For the average annual number of such pulses, streamgages with a diminished condition typically were in the western half of Kansas and streamgages with an inflated condition typically were in the eastern half of Kansas. A diminished condition for the average magnitude of such pulses typically was indicated for streamgages in the western half of Kansas.

- Pronounced alteration was indicated for flow pulses greater than the 90th percentile. For the average duration of such pulses, streamgages with a diminished condition were throughout the State. For the average magnitude of such pulses, streamgages with a diminished condition mostly were in the western half of Kansas.

- A minimally altered condition typically was indicated for the following annual flow metrics: percentage of flow that is base flow, 10th percentile flow normalized by drainage area, median flow normalized by drainage area, and coefficient of variation of daily flows. Although, for median flow, a diminished condition was indicated for multiple streamgages in western Kansas.

- For 90th percentile flow normalized by drainage area, a diminished condition was indicated for the majority (81 percent) of streamgages throughout the State.

- Given the absence of a pronounced trend in annual precipitation in Kansas, a precipitation-related explanation for streamflow alteration was not supported.
- Groundwater pumping from the High Plains aquifer likely was responsible, in part, for diminished flow conditions in western and central Kansas.

- The implementation of agricultural land-management practices to reduce runoff may have been responsible, in part, for the diminished duration and magnitude of high flows indicated for many streamgages throughout the State. In addition, such practices may have been partly responsible for an inflated magnitude of low flows at several streamgages in central and eastern Kansas.

- In general, for streamgages downstream from 20 large reservoirs, a diminished flow condition was indicated for the 8 western reservoirs and a minimally altered flow condition was indicated for the 12 eastern reservoirs.

- For the three streamgages within a predominantly urban basin, a flashier flow regime was indicated compared with what would be expected for a leastdisturbed condition.

\section{References Cited}

Bailey, R.C., Norris, R.H., and Reynoldson, T.B., 2004, Bioassessment of freshwater ecosystems - Using the reference condition approach: Norwell, Mass., Kluwer Academic Publishers, $170 \mathrm{p}$.

Barlow, P.M., and Leake, S.A., 2012, Streamflow depletion by wells-Understanding and managing the effects of groundwater pumping on streamflow: U.S. Geological Survey Circular 1376, 84 p. [Also available at https://pubs.er.usgs. gov/publication/cir1376.]

Bhaskar, A.S., Beesley, L., Burns, M.J., Fletcher, T.D., Hamel, P., Oldham, C.E., and Roy, A.H., 2016, Will it rise or will it fall?-Managing the complex effects of urbanization on base flow: Freshwater Science, v. 35, no. 1, p. 293-310.

Brunsell, N.A., Jones, A.R., Jackson, T.L., and Feddema, J.J., 2010, Seasonal trends in air temperature and precipitation in IPCC AR4 GCM output for Kansas, USA-Evaluation and implications: International Journal of Climatology, v. 30, no. 8, p. 1178-1193.

Bunn, S.E., and Arthington, A.H., 2002, Basic principles and ecological consequences of altered flow regimes for aquatic biodiversity: Environmental Management, v. 30, no. 4, p. 492-507. 
Carlisle, D.M., Falcone, James, Wolock, D.M., Meador, M.R., and Norris, R.H., 2010, Predicting the natural flow regime-Models for assessing hydrological alteration in streams: River Research and Applications, v. 26, no. 2, p. 118-136.

Carlisle, D.M., Wolock, D.M., and Meador, M.R., 2011, Alteration of streamflow magnitudes and potential ecological consequences - A multiregional assessment: Frontiers in Ecology and the Environment, v. 9, no. 5, p. 264-270.

Cutler, D.R., Edwards, T.C., Jr., Beard, K.H., Cutler, Adele, Hess, K.T., Gibson, Jacob, and Lawler, J.J., 2007, Random forests for classification in ecology: Ecology, v. 88, no. 11, p. 2783-2792.

Dodds, W.K., Gido, Keith, Whiles, M.R., Fritz, K.M., and Matthews, W.J., 2004, Life on the edge-The ecology of Great Plains prairie streams: BioScience, v. 54, no. 3, p. $205-216$.

Eng, Ken, Grantham, T.E., Carlisle, D.M., and Wolock, D.M., in press, Predictability and selection of hydrologic metrics in riverine ecohydrology: Freshwater Sciences.

Eng, Ken, and Milly, P.C.D., 2007, Relating low-flow characteristics to the base flow recession time constant at partial record stream gauges: Water Resources Research, v. 43, no. 1, W01201, accessed March 23, 2016, at https://doi. org/10.1029/2006WR005293.

Falcone, J.A., 2011, GAGES-II-Geospatial attributes of gages for evaluating streamflow: U.S. Geological Survey dataset, accessed June 23, 2016, at https:/water.usgs.gov/ GIS/metadata/usgswrd/XML/gagesII_Sept2011.xml.

Falcone, J.A., Carlisle, D.M., Wolock, D.M., and Meador, M.R., 2010, GAGES - A stream gage database for evaluating natural and altered flow conditions in the conterminous United States: Ecology, v. 91, no. 2, p. 621.

Gebert, W.A., and Krug, W.R., 1996, Streamflow trends in Wisconsin's driftless area: Water Resources Bulletin, v. 32, no. 4 , p. 733-744.

Gido, K.B., Dodds, W.K., and Eberle, M.E., 2010, Retrospective analysis of fish community change during a half-century of landuse and streamflow changes: Journal of the North American Benthological Society, v. 29, no. 3, p. 970-987.

Graf, W.L., 2006, Downstream hydrologic and geomorphic effects of large dams on American rivers: Geomorphology, v. 79, nos. 3-4, p. 336-360.
Granato, G.E., 2009, Computer programs for obtaining and analyzing daily mean streamflow data from the U. S. Geological Survey National Water Information System web site: U.S. Geological Survey Open-File Report 2008-1362, 8 p., appendixes, 1 CD-ROM. [Also available at https://pubs. er.usgs.gov/publication/ofr20081362.]

Gutentag, E.D., Heimes, F.J., Krothe, N.C., Luckey, R.R., and Weeks, J.B., 1984, Geohydrology of the High Plains aquifer in parts of Colorado, Kansas, Nebraska, New Mexico, Oklahoma, South Dakota, Texas, and Wyoming: U.S. Geological Survey Professional Paper 1400-B, 63 p. [Also available at https://pubs.er.usgs.gov/publication/pp1400B.]

Haslouer, S.G., Eberle, M.E., Edds, D.R., Gido, K.B., Mammoliti, C.S., Triplett, J.R., Collins, J.T., Distler, D.A., Huggins, D.G., and Stark, W.J., 2005, Current status of native fish species in Kansas: Transactions of the Kansas Academy of Science, v. 108, p. 32-46.

Hoagstrom, C.W., Brooks, J.E., and Davenport, S.R., 2011, A large-scale conservation perspective considering endemic fishes of the North American plains: Biological Conservation, v. 144 , no. 1, p. 21-34.

Hopkins, K.G., Morse, N.B., Bain, D.J., Bettez, N.D., Grimm, N.B., Morse, J.L., Palta, M.M., Shuster, W.D., Bratt, A.R., and Suchy, A.K., 2015, Assessment of regional variation in streamflow responses to urbanization and the persistence of physiography: Environmental Science \& Technology, v. 49, no. 5, p. 2724-2732.

Jaiantilal, Abhishek, 2009, randomforest-matlab: Google Code open source, accessed June 2, 2011, at http://code.google. $\mathrm{com} / \mathrm{p} /$ randomforest-matlab/.

Jin, Suming, Yang, Limin, Danielson, Patrick, Homer, Collin, Fry, Joyce, and Xian, George, 2013, A comprehensive change detection method for updating the National Land Cover Database to circa 2011: Remote Sensing of Environment, v. 132, p. 159-175.

Jordan, P.R., 1982, Rainfall-runoff relations and expected streamflow in western Kansas: Kansas Water Office Bulletin $25,42 \mathrm{p}$.

Juckem, P.F., Hunt, R.J., Anderson, M.P., and Robertson, D.M., 2008, Effects of climate and land management change on streamflow in the driftless area of Wisconsin: Journal of Hydrology, v. 355, nos. 1-4, p. 123-130.

Juracek, K.E., 2015, Streamflow characteristics and trends at selected streamgages in southwest and south-central Kansas: U.S. Geological Survey Scientific Investigations Report 2015-5167, 20 p. [Also available at https://doi.org/10.3133/ $\operatorname{sir} 20155167$. 
Juracek, K.E., Eng, Ken, Carlisle, D.M., and Wolock, D.M., 2017, Streamflow alteration and habitat ramifications for a threatened fish species in the central United States: River Research and Applications. [Also available at https://doi. org/10.1002/rra.3148. ]

Kansas Water Resources Board, 1958, State water plan studies; Part A-Preliminary appraisal of Kansas water problems; Section 2-Cimarron unit: Kansas Water Resources Board, $124 \mathrm{p}$.

Kansas Water Resources Board, 1960, State water plan studies; Part A-Preliminary appraisal of Kansas water problems; Section 4-Lower Arkansas unit: Kansas Water Resources Board, 177 p.

Kennard, M.J., Mackay, S.J., Pusey, B.J., Olden, J.D., and Marsh, Nick, 2010, Quantifying uncertainty in estimation of hydrologic metrics for ecohydrological studies: River Research and Applications, v. 26, no. 2, p. 137-156.

Kenny, J.F., and Juracek, K.E., 2013, Irrigation trends in Kansas, 1991-2011: U.S. Geological Survey Fact Sheet 2013-3094, 4 p. [Also available at https://doi.org/10.3133/ fs20133094.]

Knighton, David, 1998, Fluvial forms and processes - A new perspective: New York, John Wiley \& Sons, 383 p.

Knox, J.C., 2001, Agricultural influence on landscape sensitivity in the upper Mississippi River valley: Catena, v. 42, nos. 2-4, p. 193-224.

Kondolf, G.M., 1997, Hungry water-Effects of dams and gravel mining on river channels: Environmental Management, v. 21, no. 4, p. 533-551.

Kramer, L.A., Burkart, M.R., Meek, D.W., Jaquis, R.J., and James, D.E., 1999, Field-scale watershed evaluations on deep-loess soils - II. Hydrologic responses to different agricultural land management systems: Journal of Soil and Water Conservation, v. 54, no. 4, p. 705-710.

Magilligan, F.J., and Nislow, K.H., 2005, Changes in hydrologic regime by dams: Geomorphology, v. 71, nos. 1-2, p. 61-78.

McGuire, V.L., 2014, Water-level changes and change in water in storage in the High Plains aquifer, predevelopment to 2013 and 2011-13: U.S. Geological Survey Scientific Investigations Report 2014-5218, 14 p., data, accessed March 24, 2016, at https://doi.org/10.3133/sir20145218.

Moody, D.W., Chase, E.B., and Aronson, D.A., comps., 1986, National water summary 1985-Hydrologic events and surface-water resources: U.S. Geological Survey WaterSupply Paper 2300, 506 p. [Also available at https://pubs. er.usgs.gov/publication/wsp2300.]
Moriasi, D.N., Arnold, J.G., Van Liew, M.W., Bingner, R.L., Harmel, R.D., and Veith, T.L., 2007, Model evaluation guidelines for systematic quantification of accuracy in watershed simulations: Transactions of the American Society of Agricultural and Biological Engineers, v. 50, no. 3, p. 885-900.

Nash, J.E., and Sutcliffe, J.V., 1970, River flow forecasting through conceptual models; Part 1-A discussion of principles: Journal of Hydrology, v. 10, no. 3, p. 282-290.

National Oceanic and Atmospheric Administration, 2016, 1981-2010 U.S. climate normals: National Oceanic and Atmospheric Administration data, accessed April 2016 at https://www.ncdc.noaa.gov/data-access/land-based-stationdata/land-based-datasets/climate-normals/1981-2010-normals-data.

Newman, A.J., Clark, M.P., Sampson, K., Wood, A., Hay, L.E., Bock, A., Viger, R.J., Blodgett, D., Brekke, L., Arnold, J.R., Hopson, T., and Duan, Q., 2015, Development of a largesample watershed-scale hydrometeorological data set for the contiguous USA - data set characteristics and assessment of regional variability in hydrologic model performance: Hydrology and Earth System Sciences, v. 19, no. 1, p. 209-223.

Olden, J.D., and Poff, N.L., 2003, Redundancy and the choice of hydrologic indices for characterizing streamflow regimes: River Research and Applications, v. 19, no. 2, p. 101-121.

Perkin, J.S., Gido, K.B., Cooper, A.R., Turner, T.F., Osborne, M.J., Johnson, E.R., and Mayes, K.B., 2015, Fragmentation and dewatering transform Great Plains stream fish communities: Ecological Monographs, v. 85, no. 1, p. 73-92.

Peterson, D.L., Whistler, J.L., Egbert, S.L., and Martinko, E.A., 2010, 2005 Kansas land cover patterns; Phase IIFinal report: Kansas Biological Survey Report 167, 49 p.

Poff, N.L., Allan, J.D., Bain, M.B., Karr, J.R., Prestegaard, K.L., Richter, B.D., Sparks, R.E., and Stromberg, J.C., 1997, The natural flow regime-A paradigm for river conservation and restoration: BioScience, v. 47 , no. 11 , p. 769-784.

Poff, N.L., and Zimmerman, J.K.H., 2010, Ecological responses to altered flow regimes-A literature review to inform the science and management of environmental flows: Freshwater Biology, v. 55, no. 1, p. 194-205.

Potter, K.W., 1991, Hydrological impacts of changing land management practices in a moderate-sized agricultural catchment: Water Resources Research, v. 27, no. 5, p. $845-855$. 
Putnam, J.E., Perry, C.A., and Wolock, D.M., 2008, Hydrologic droughts in Kansas-Are they becoming worse? U.S. Geological Survey Fact Sheet 2008-3034, 6 p. [Also available at https://pubs.er.usgs.gov/publication/ fs20083034.]

Rasmussen, T.J., and Gatotho, Jackline, 2014, Water-quality variability and constituent transport in streams of Johnson County, Kansas, using continuous monitoring and regression models, 2003-11: U.S. Geological Survey Scientific Investigations Report 2013-5221, 53 p., accessed April 2016 at https://doi.org/10.3133/sir20135221.

Rasmussen, T.J., and Perry, C.A., 2001, Trends in peak flows of selected streams in Kansas: U.S. Geological Survey Water-Resources Investigations Report 2001-4203, 62 p. [Also available at https://pubs.er.usgs.gov/publication/ wri014203.]

Rose, Seth, and Peters, N.E., 2001, Effects of urbanization on streamflow in the Atlanta area (Georgia, USA) - A comparative hydrological approach: Hydrological Processes, v. 15, no. 8 , p. 1441-1457.

Turnipseed, D.P., and Sauer, V.B., 2010, Discharge measurements at gaging stations: U.S. Geological Survey Techniques and Methods, book 3, chap. A8, 87 p. [Also available at https://pubs.er.usgs.gov/publication/tm3A8.]

U.S. Geological Survey, 2016, USGS water data for the nation: U.S. Geological Survey National Water Information System web interface, accessed June 1, 2016, at https://doi. org/10.5066/F7P55KJN.

Walsh, C.J., Roy, A.H., Feminella, J.W., Cottingham, P.D., Groffman, P.M., and Morgan, R.P., II, 2005, The urban stream syndrome-Current knowledge and the search for a cure: Journal of the North American Benthological Society, v. 24 , no. 3, p. 706-723.

Walsh, John; Wuebbles, Donald; Hayhoe, Katharine; Kossin, James; Kunkel, Kenneth; Stephens, Graeme; Thorne, Peter; Vose, Russell; Wehner, Michael; Willis, Josh; Anderson, David; Doney, Scott; Feely, Richard; Hennon, Paula; Kharin, Viatcheslav; Knutson, Thomas; Landerer, Felix; Lenton, Tim; Kennedy, John; and Somerville, Richard, 2014, Our changing climate, chap. 2 of Melillo, J.M., Richmond, T.C., and Yohe, G.W., eds., Climate change impacts in the United States: U.S. Global Change Research Program, p. 19-67. [Also available at https://doi.org/10.7930/J0KW5CXT.]

Weeks, J.B., Gutentag, E.D., Heimes, F.J., and Luckey, R.R., 1988, Summary of the High Plains regional aquifer-system analysis in parts of Colorado, Kansas, Nebraska, New Mexico, Oklahoma, South Dakota, Texas, and Wyoming: U.S. Geological Survey Professional Paper 1400-A, 30 p. [Also available at https://pubs.er.usgs.gov/publication/ pp1400A.]
Whittemore, D.O., Butler, J.J., Jr., and Wilson, B.B., 2016, Assessing the major drivers of water-level declines-New insights into the future of heavily stressed aquifers: Hydrological Sciences Journal, v. 61, no. 1, p. 134-145.

Williams, G.P., and Wolman, M.G., 1984, Downstream effects of dams on alluvial rivers: U.S. Geological Survey Professional Paper 1286, 83 p. [Also available at https://pubs. er.usgs.gov/publication/pp1286.]

Winter, T.C., 2007, The role of ground water in generating streamflow in headwater areas and in maintaining base flow: Journal of the American Water Resources Association, v. 43, no. 1, p. $15-25$.

Young, D.P., Macfarlane, P.A., Whittemore, D.O., and Wilson, B.B., 2005, Hydrogeologic characteristics and hydrologic changes in the Cimarron River Basin, southwestern Kansas: Kansas Geological Survey Open-File Report 2005-26, 41 p.

Zhang, Y.-K., and Schilling, K.E., 2006, Increasing streamflow and baseflow in Mississippi River since the 1940s-Effect of land use change: Journal of Hydrology, v. 324, nos. 1-4, p. 412-422. 

Figures 3-31 


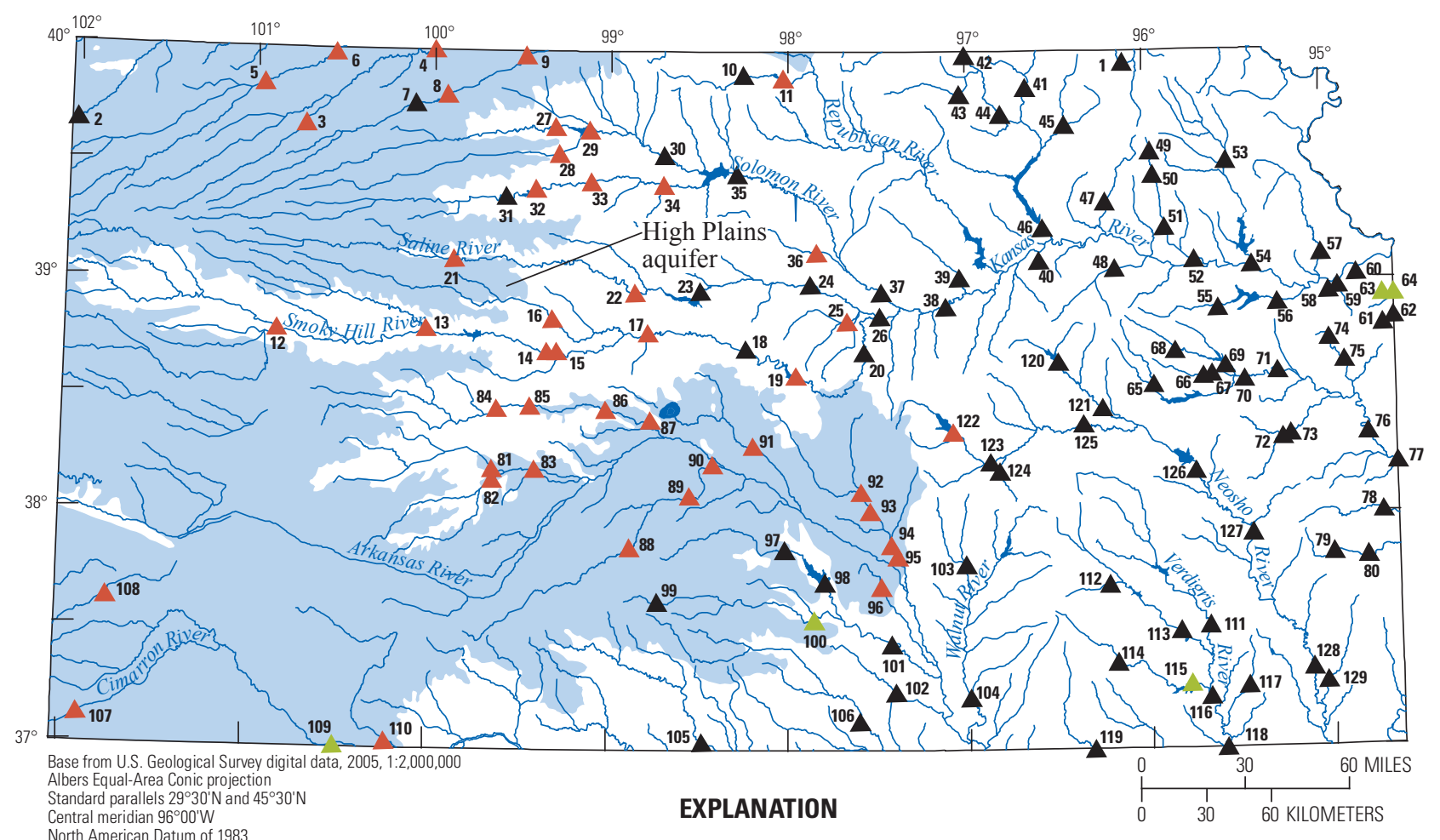

U.S. Geological Survey streamgage and identifier (table 2)-Mean January flow normalized by drainage area

${ }_{110} \triangle$ Diminished flow condition $\quad 100 \triangle$ Inflated flow condition

${ }^{106} \Delta$ Minimally altered flow condition

Figure 3. Condition of mean January flow normalized by drainage area for 129 streamgages in Kansas. 


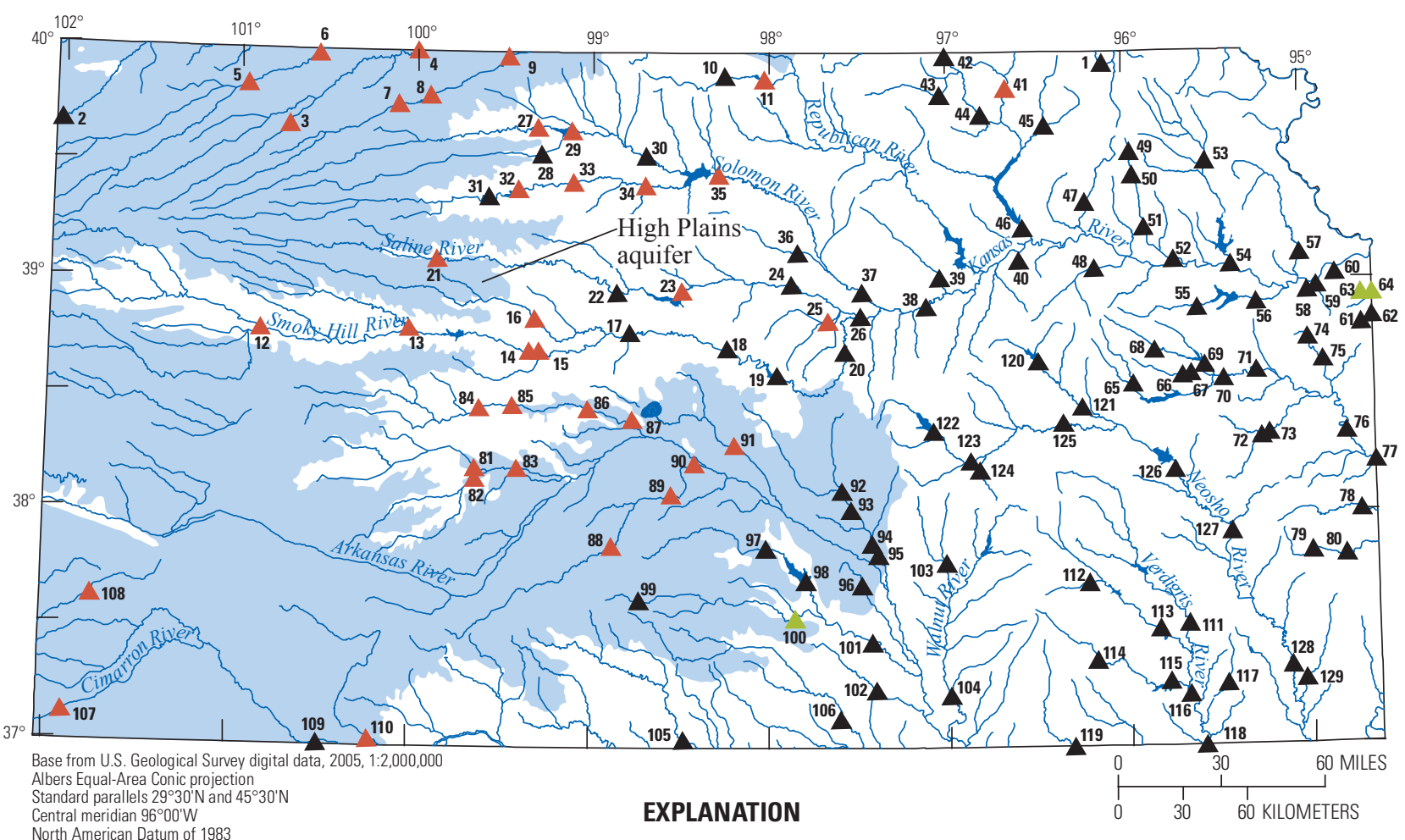

U.S. Geological Survey streamgage and identifier (table 2)—Mean February flow normalized by drainage area

$110 \triangle$ Diminished flow condition $\quad 100 \Delta$ Inflated flow condition

${ }^{109} \boldsymbol{A}$ Minimally altered flow condition

Figure 4. Condition of mean February flow normalized by drainage area for 129 streamgages in Kansas. 


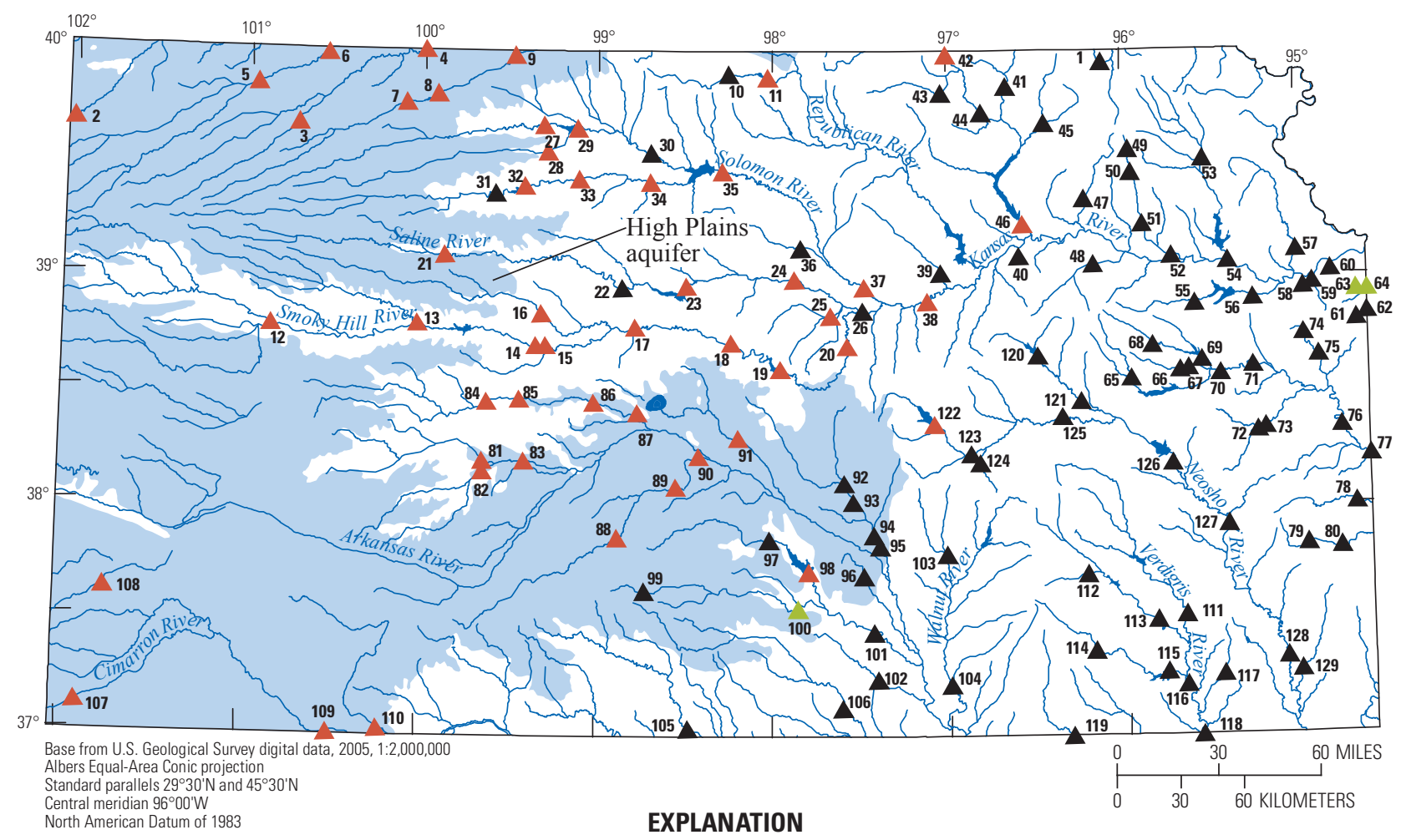

U.S. Geological Survey streamgage and identifier (table 2)—Mean March flow normalized by drainage area

${ }^{110} \triangle$ Diminished flow condition $\quad 100 \Delta$ Inflated flow condition

${ }^{105} \triangle$ Minimally altered flow condition

Figure 5. Condition of mean March flow normalized by drainage area for 129 streamgages in Kansas. 


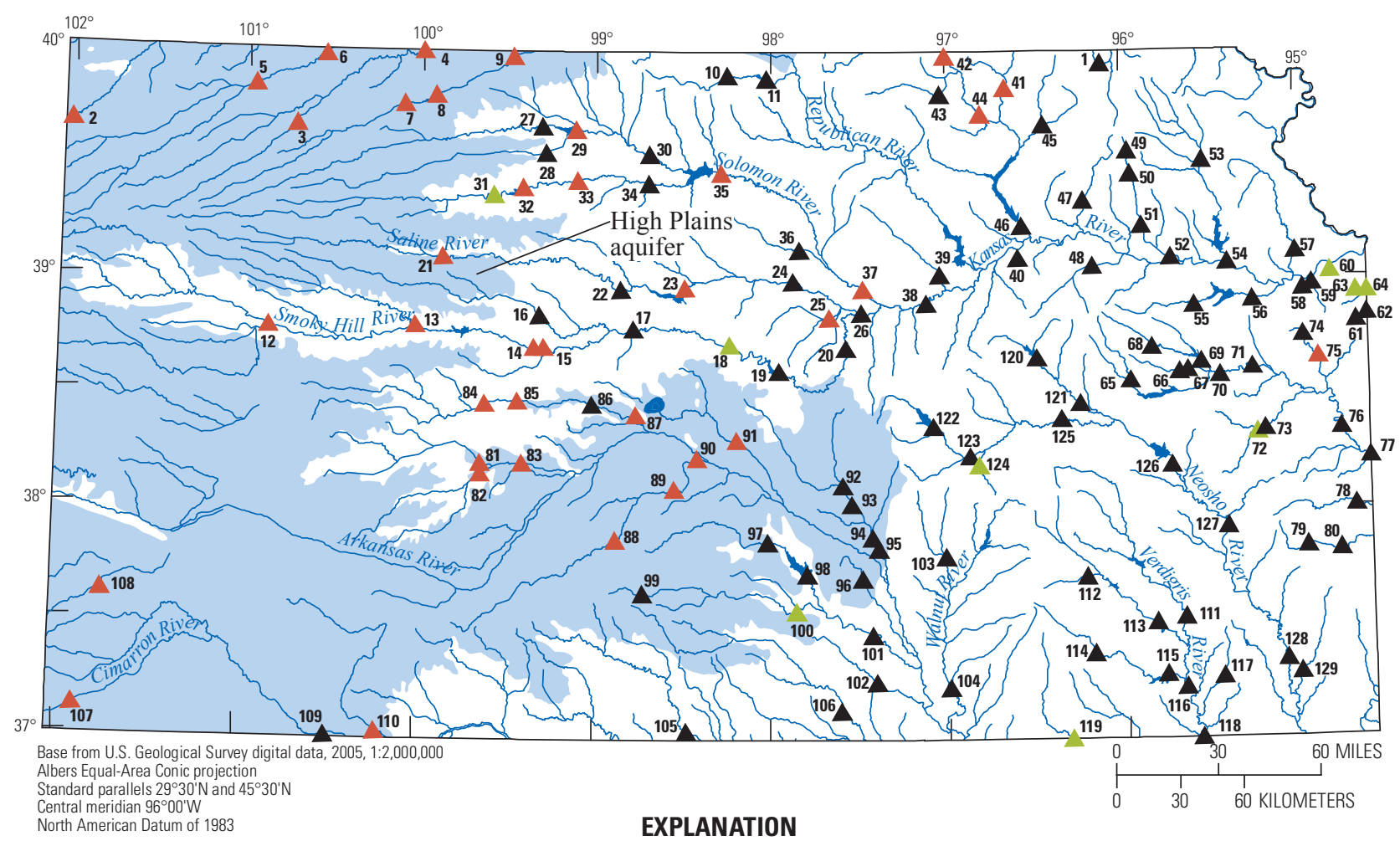

U.S. Geological Survey streamgage and identifier (table 2)—Mean April flow normalized by drainage area

110 Diminished flow condition

$100 \triangle$ Inflated flow condition

${ }^{109} \boldsymbol{A}$ Minimally altered flow condition

Figure 6. Condition of mean April flow normalized by drainage area for 129 streamgages in Kansas. 


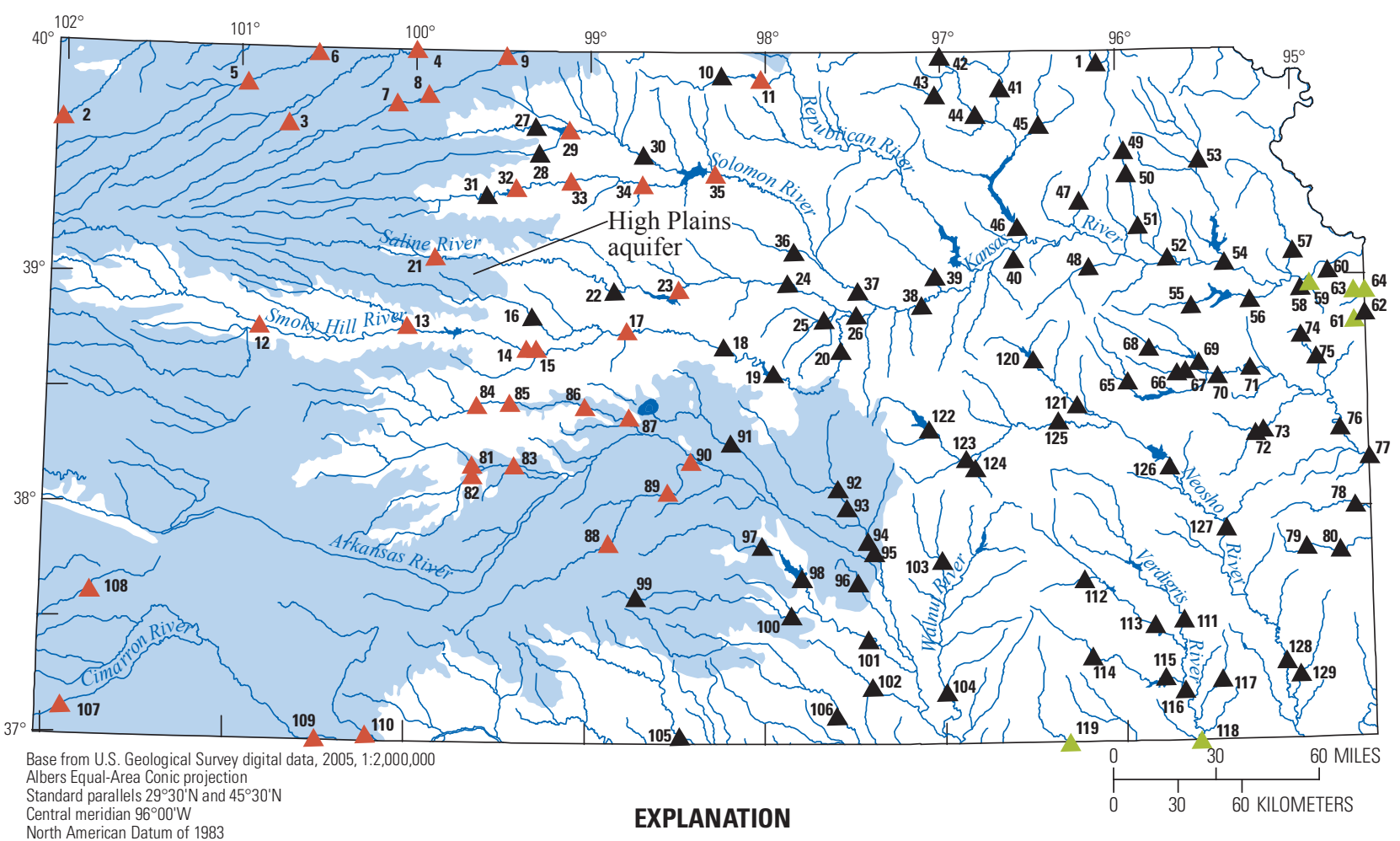

U.S. Geological Survey streamgage and identifier (table 2)-Mean May flow normalized by drainage area

${ }^{110} \Delta$ Diminished flow condition $\quad 119 \Delta$ Inflated flow condition

105 Minimally altered flow condition

Figure 7. Condition of mean May flow normalized by drainage area for 129 streamgages in Kansas. 


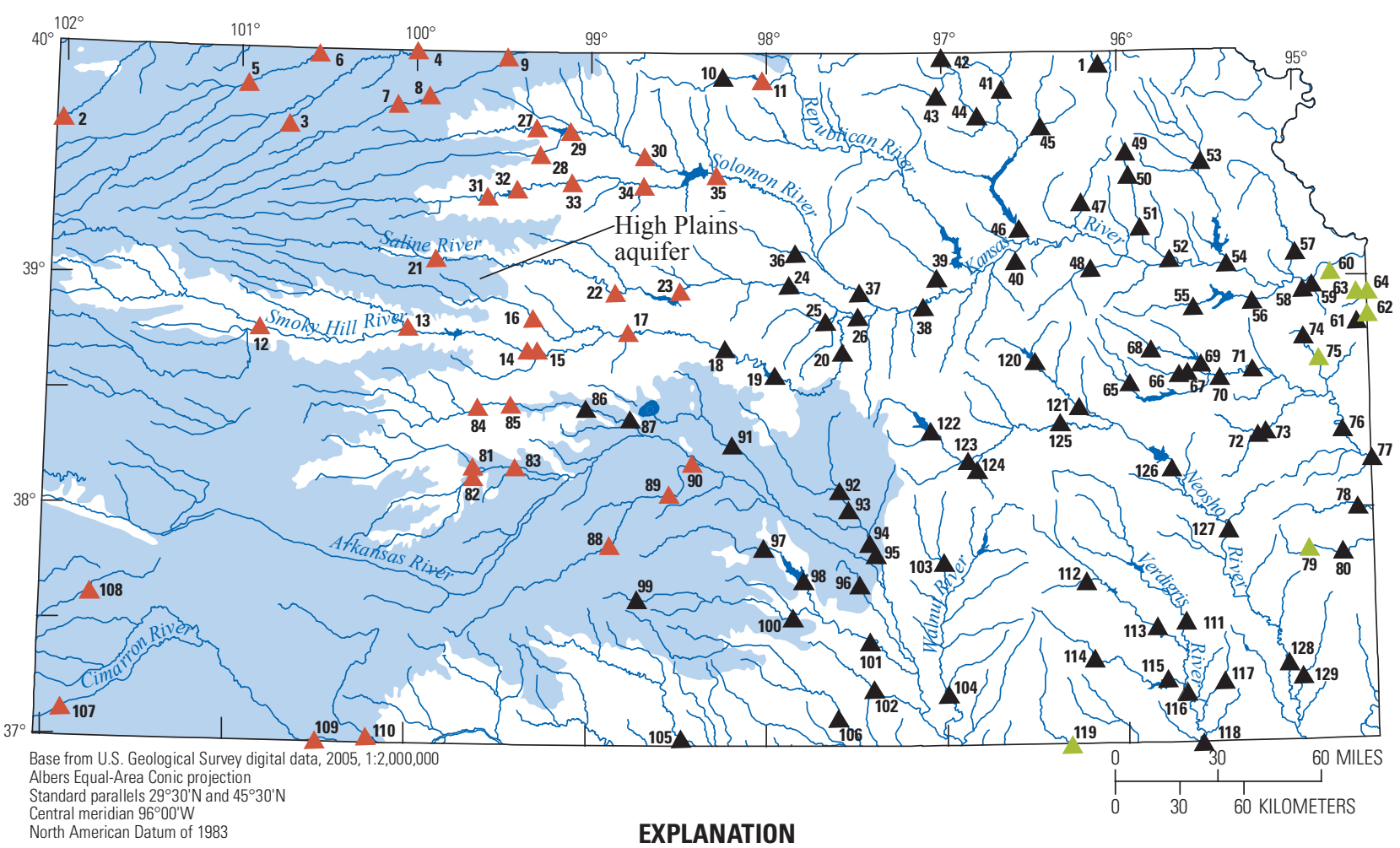

U.S. Geological Survey streamgage and identifier (table 2)-Mean June flow normalized by drainage area

${ }_{110}$ Diminished flow condition

$119 \triangle$ Inflated flow condition

${ }^{105} \Delta$ Minimally altered flow condition

Figure 8. Condition of mean June flow normalized by drainage area for 129 streamgages in Kansas. 


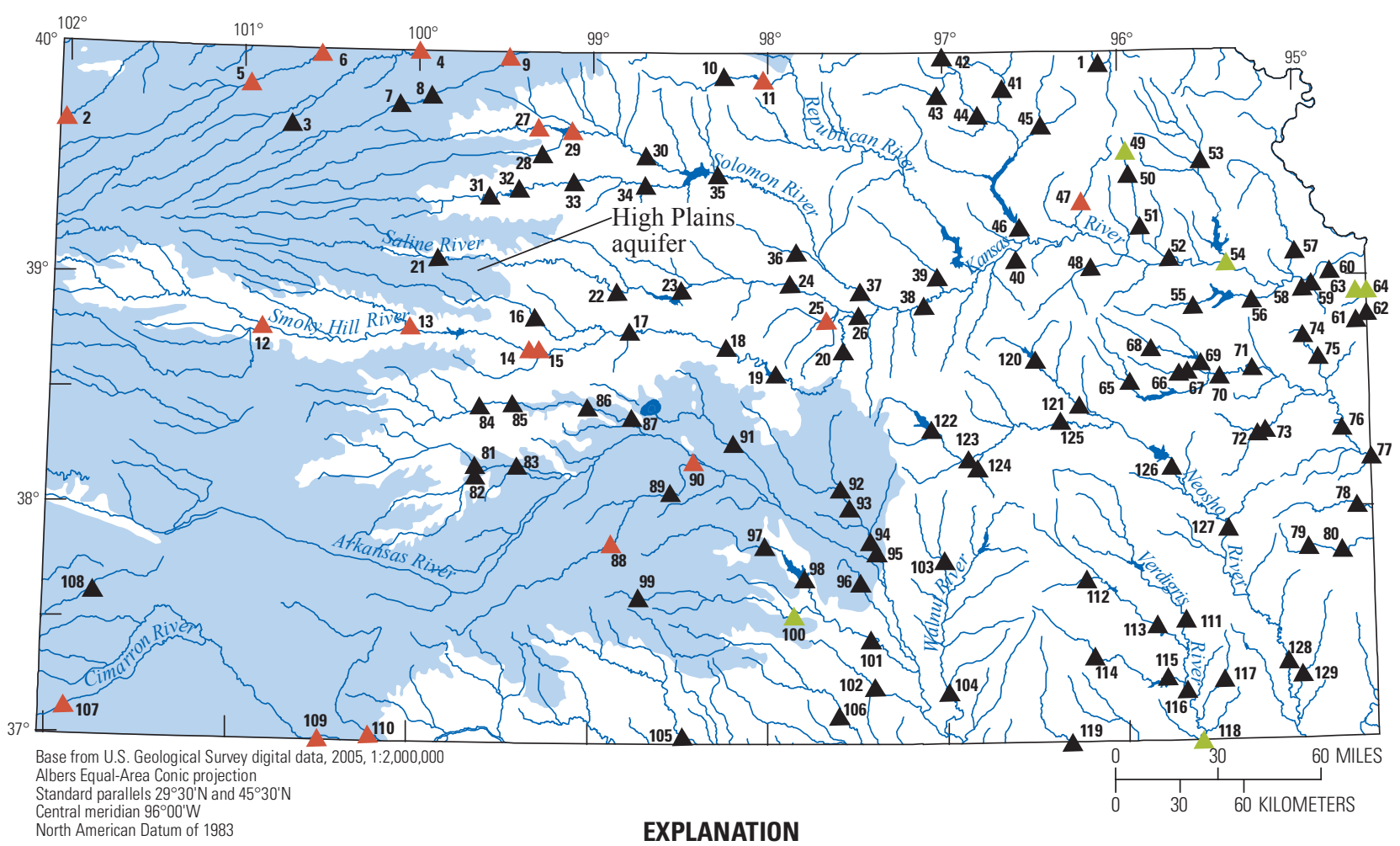

U.S. Geological Survey streamgage and identifier (table 2)—Mean July flow normalized by drainage area

${ }^{110} \triangle$ Diminished flow condition $118 \triangle$ Inflated flow condition

${ }^{105} \Delta$ Minimally altered flow condition

Figure 9. Condition of mean July flow normalized by drainage area for 129 streamgages in Kansas. 


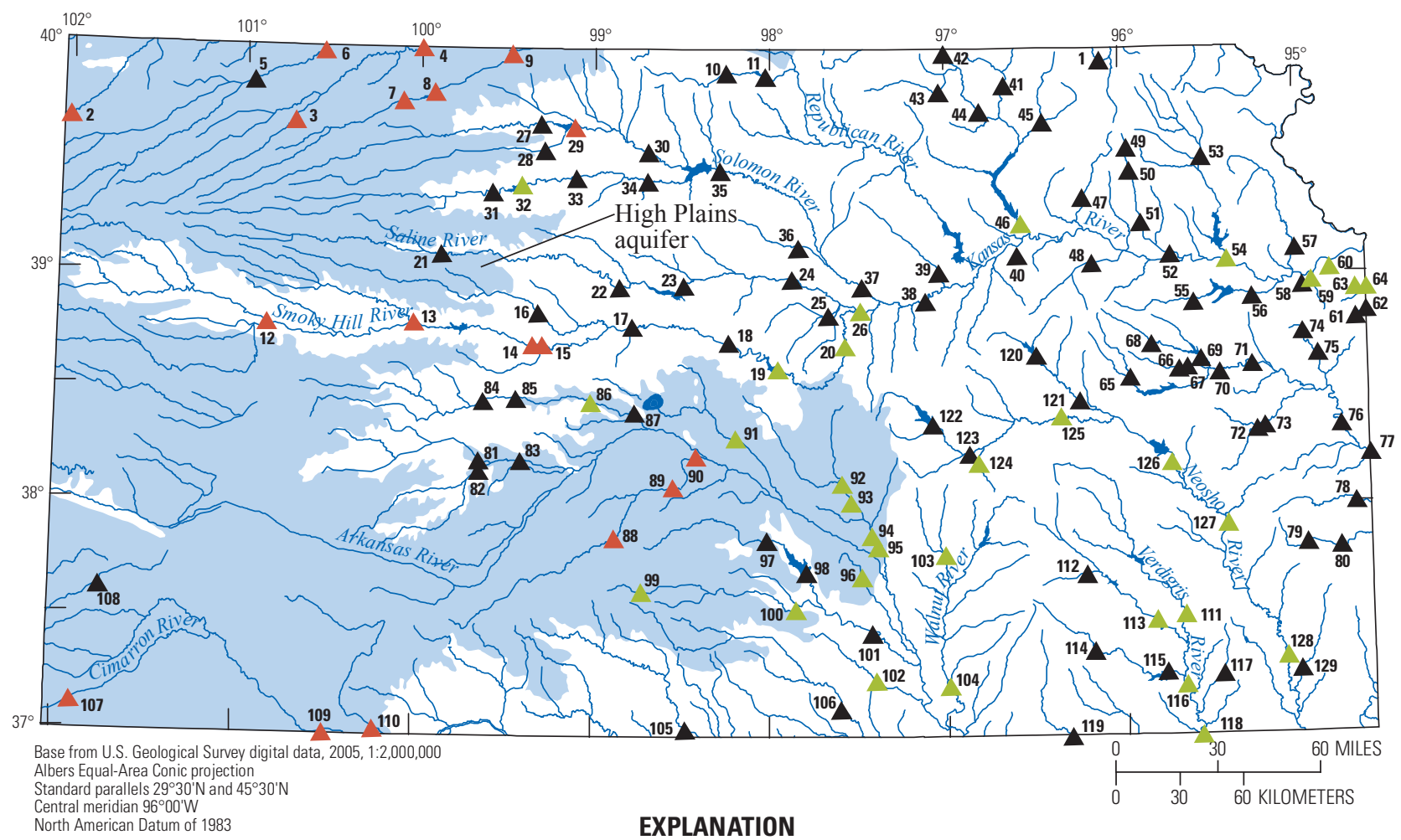

U.S. Geological Survey streamgage and identifier (table 2)-Mean August flow normalized by drainage area
$110 \triangle$ Diminished flow condition
102 Inflated flow condition
105 Minimally altered flow condition

Figure 10. Condition of mean August flow normalized by drainage area for 129 streamgages in Kansas. 


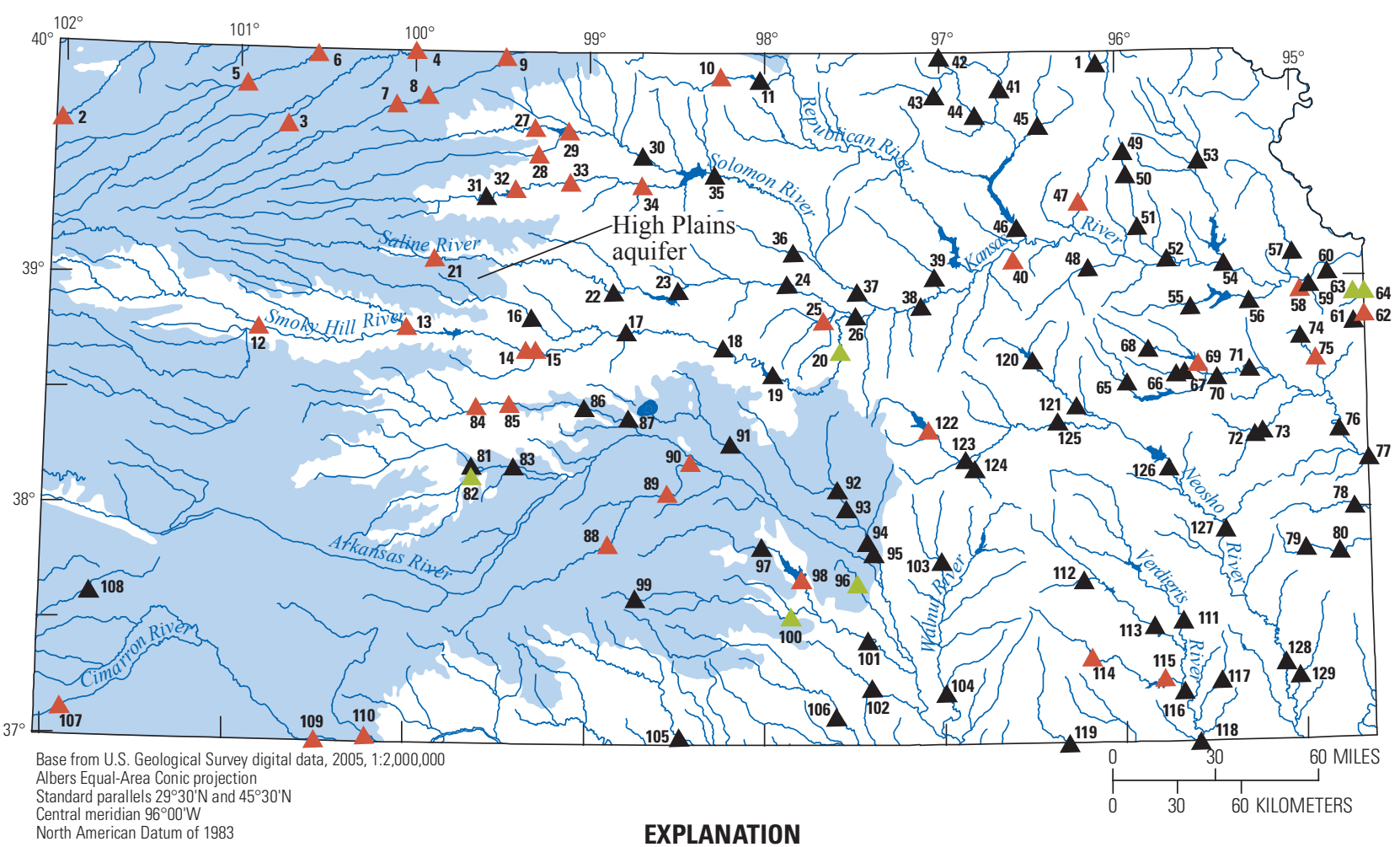

U.S. Geological Survey streamgage and identifier (table 2)—Mean September flow normalized by drainage area
${ }^{110}$ Diminished flow condition
$100 \triangle$ Inflated flow condition
105 Minimally altered flow condition

Figure 11. Condition of mean September flow normalized by drainage area for 129 streamgages in Kansas. 




\begin{abstract}
U.S. Geological Survey streamgage and identifier (table 2)-Mean October flow normalized by drainage area
\end{abstract}
${ }^{110}$ Diminished flow condition
$100 \triangle$ Inflated flow condition

${ }^{109} \Delta$ Minimally altered flow condition

Figure 12. Condition of mean October flow normalized by drainage area for 129 streamgages in Kansas. 


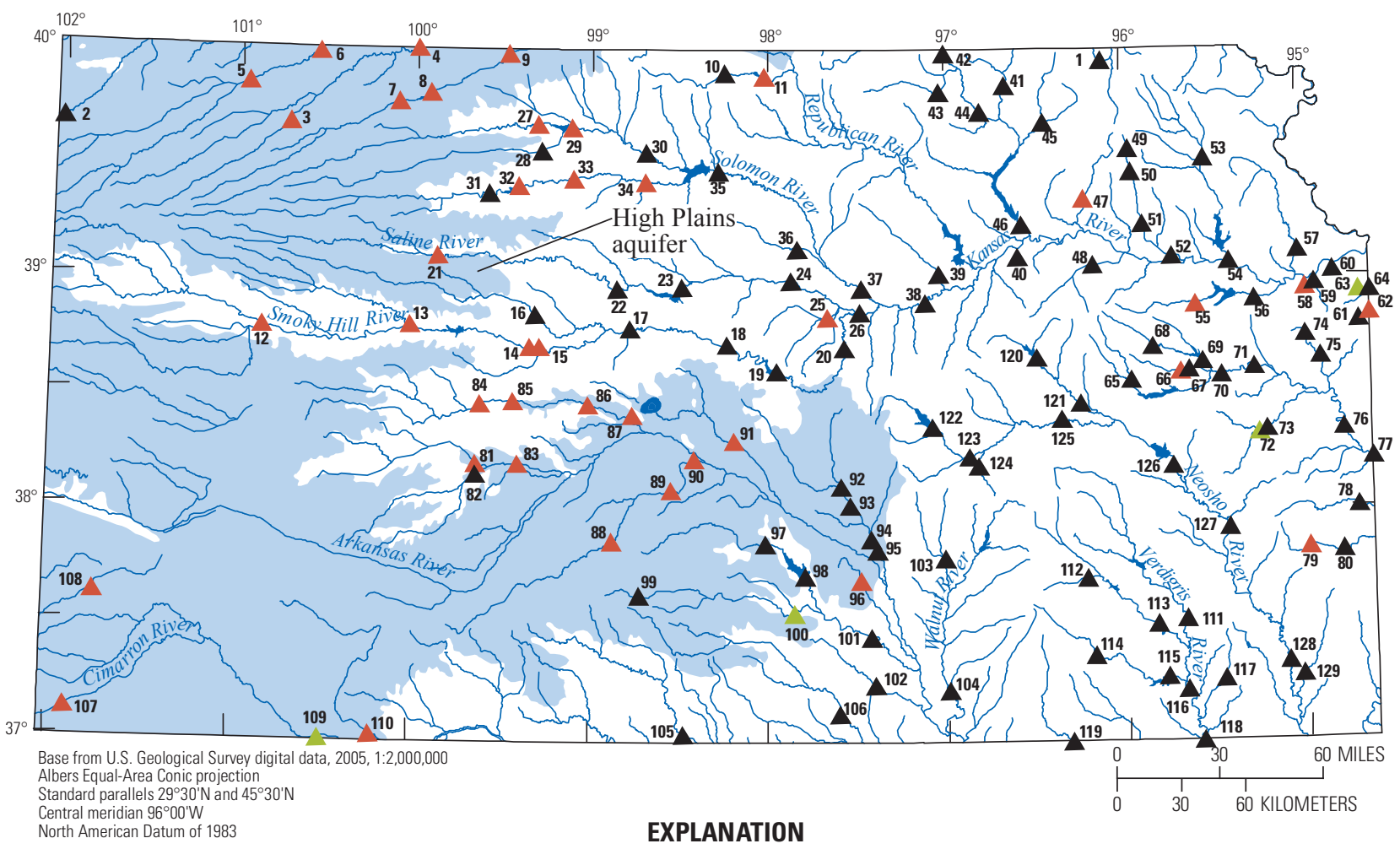

U.S. Geological Survey streamgage and identifier (table 2)—Mean November flow normalized by drainage area

$110 \triangle$ Diminished flow condition $\quad 100 \triangle$ Inflated flow condition

105 Minimally altered flow condition

Figure 13. Condition of mean November flow normalized by drainage area for 129 streamgages in Kansas. 


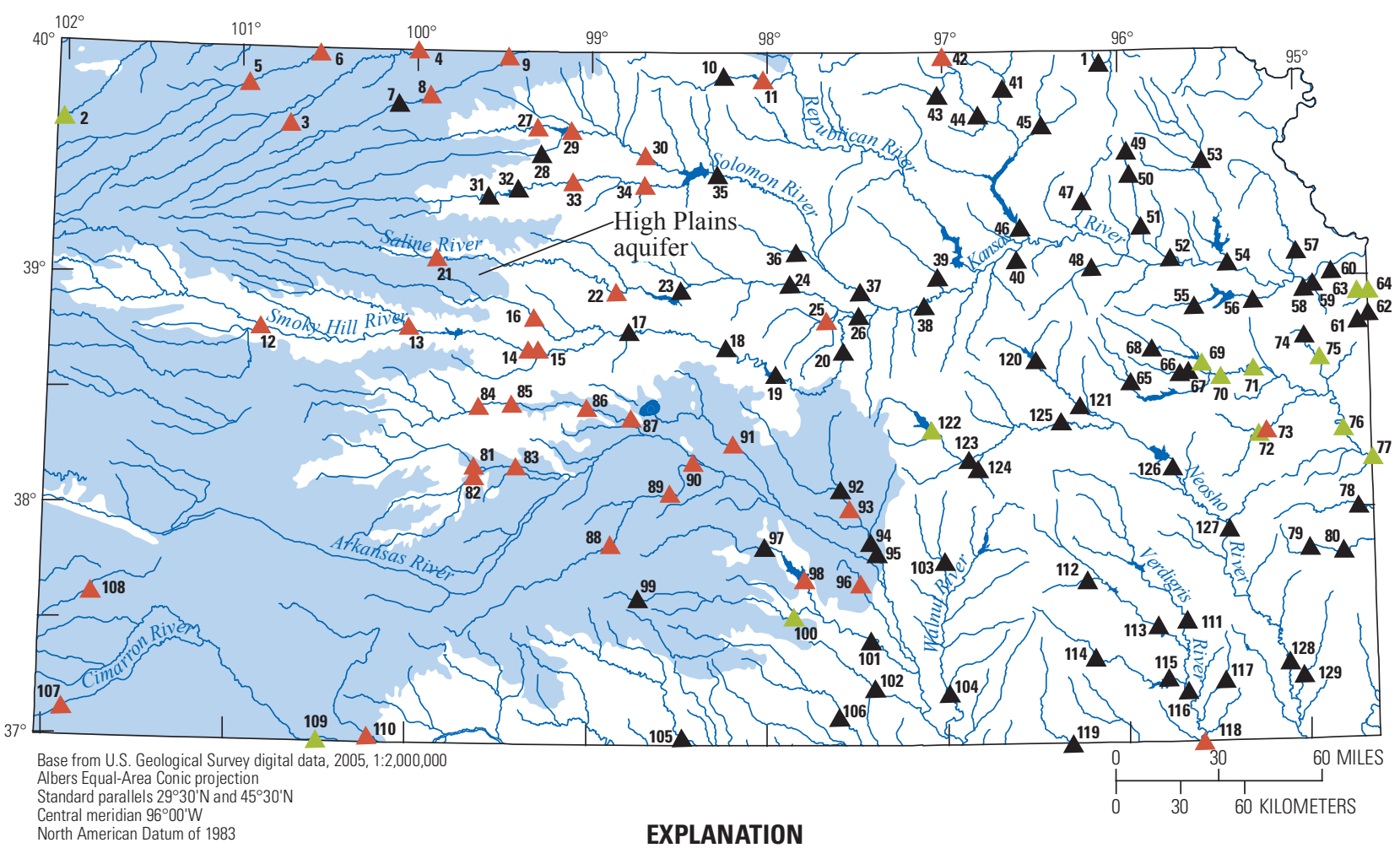

U.S. Geological Survey streamgage and identifier (table 2)-Mean December flow normalized by drainage area

110 Diminished flow condition

$100 \triangle$ Inflated flow condition

${ }^{105} \boldsymbol{A}$ Minimally altered flow condition

Figure 14. Condition of mean December flow normalized by drainage area for 129 streamgages in Kansas. 


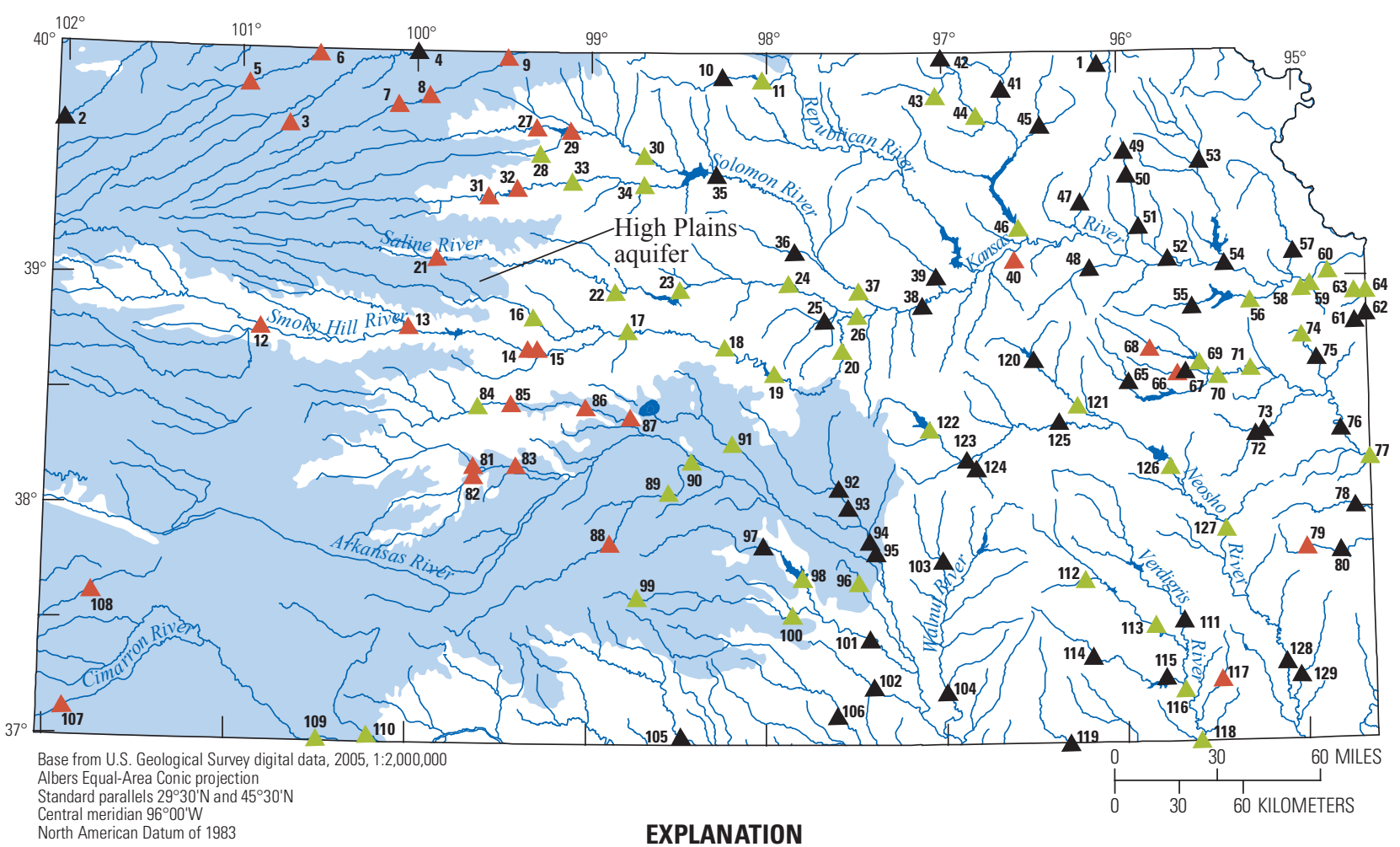

U.S. Geological Survey streamgage and identifier (table 2)—Average annual number of flow pulses less than the 10th percentile

107 Diminished flow condition

${ }^{109} \Delta$ Inflated flow condition

105 Minimally altered flow condition

Figure 15. Condition of the average annual number of flow pulses less than the 10th percentile metric for 129 streamgages in Kansas. 


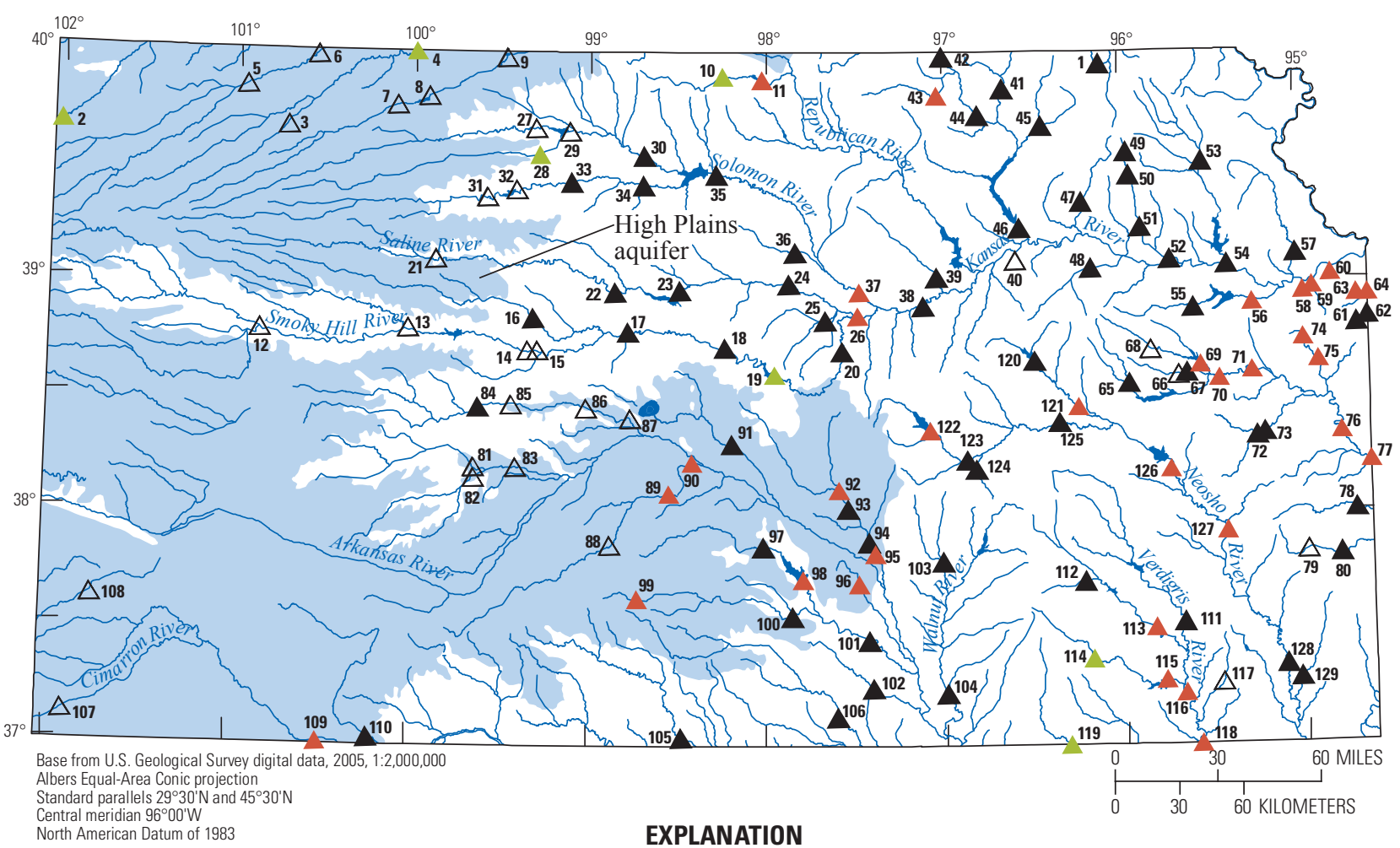

U.S. Geological Survey streamgage and identifier (table 2)—Average duration of flow pulses less than the 10th percentile
109 Diminished flow condition
119 Inflated flow condition
110 Minimally altered flow condition
${ }^{117} \triangle$ Not computed due to absence of flow

Figure 16. Condition of the average duration of flow pulses less than the 10th percentile metric for 129 streamgages in Kansas. 


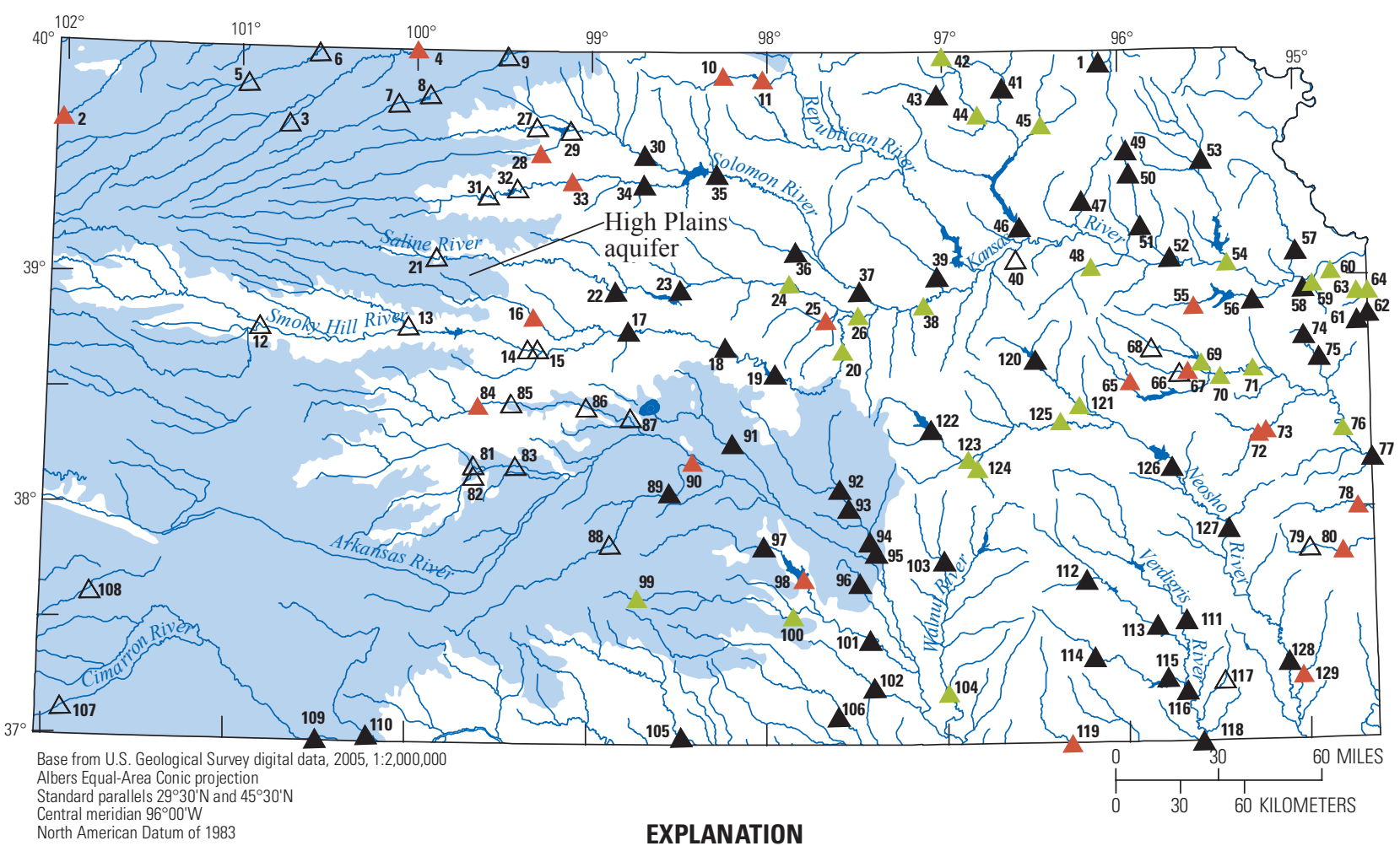

U.S. Geological Survey streamgage and identifier (table 2)—Average flow of pulses less than the 10th percentile, normalized by drainage area

${ }^{119}$ Diminished flow condition

$100 \triangle$ Inflated flow condition

110 Minimally altered flow condition

${ }^{107} \triangle$ Not computed due to absence of flow

Figure 17. Condition of the average magnitude of flow pulses less than the 10th percentile metric for 129 streamgages in Kansas. 


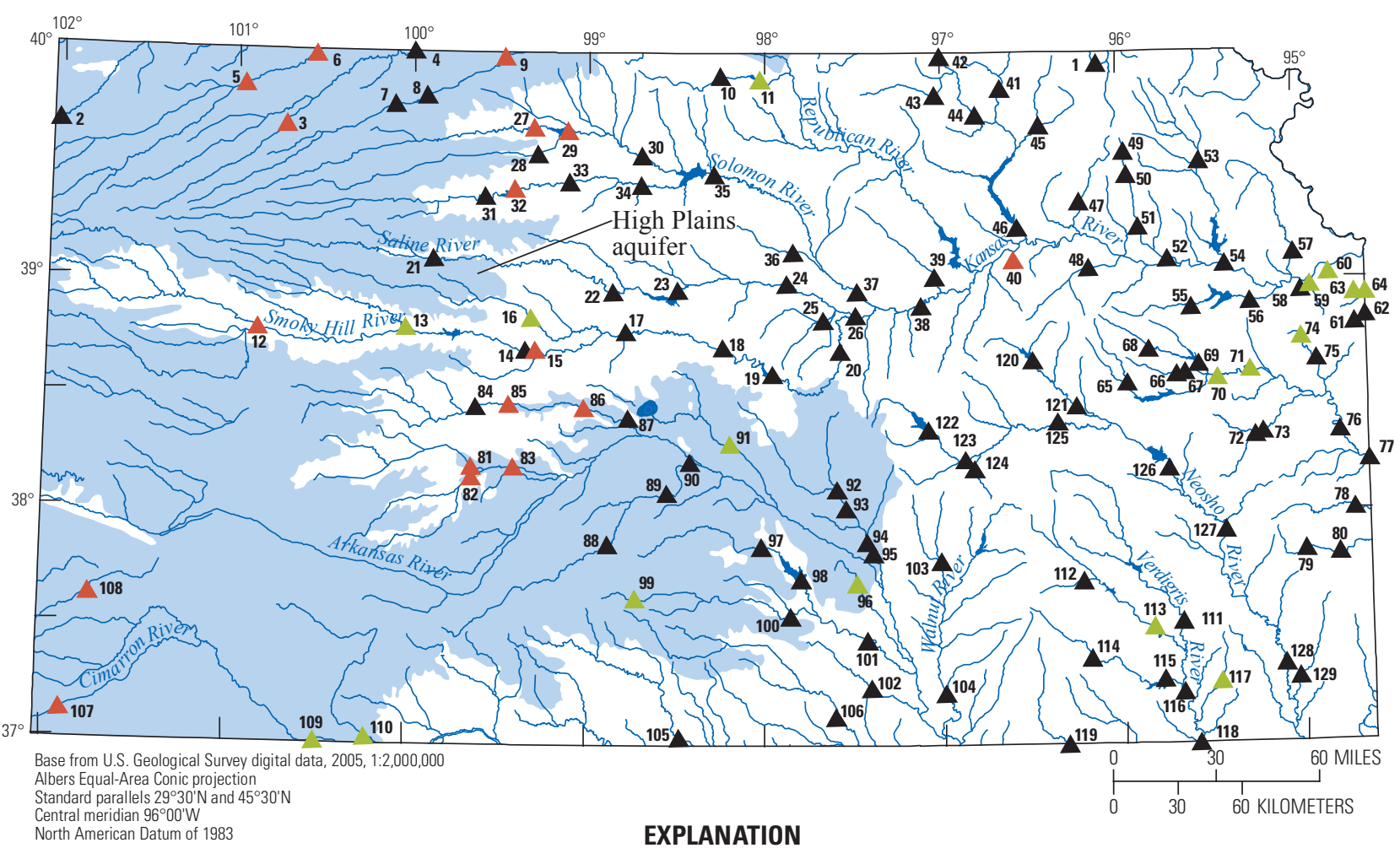

U.S. Geological Survey streamgage and identifier (table 2)—Average annual number of flow pulses less than the 25th percentile

${ }^{107} \Delta$ Diminished flow condition $\quad 109 \Delta$ Inflated flow condition

${ }^{105} \boldsymbol{\Delta}$ Minimally altered flow condition

Figure 18. Condition of the average annual number of flow pulses less than the 25th percentile metric for 129 streamgages in Kansas. 


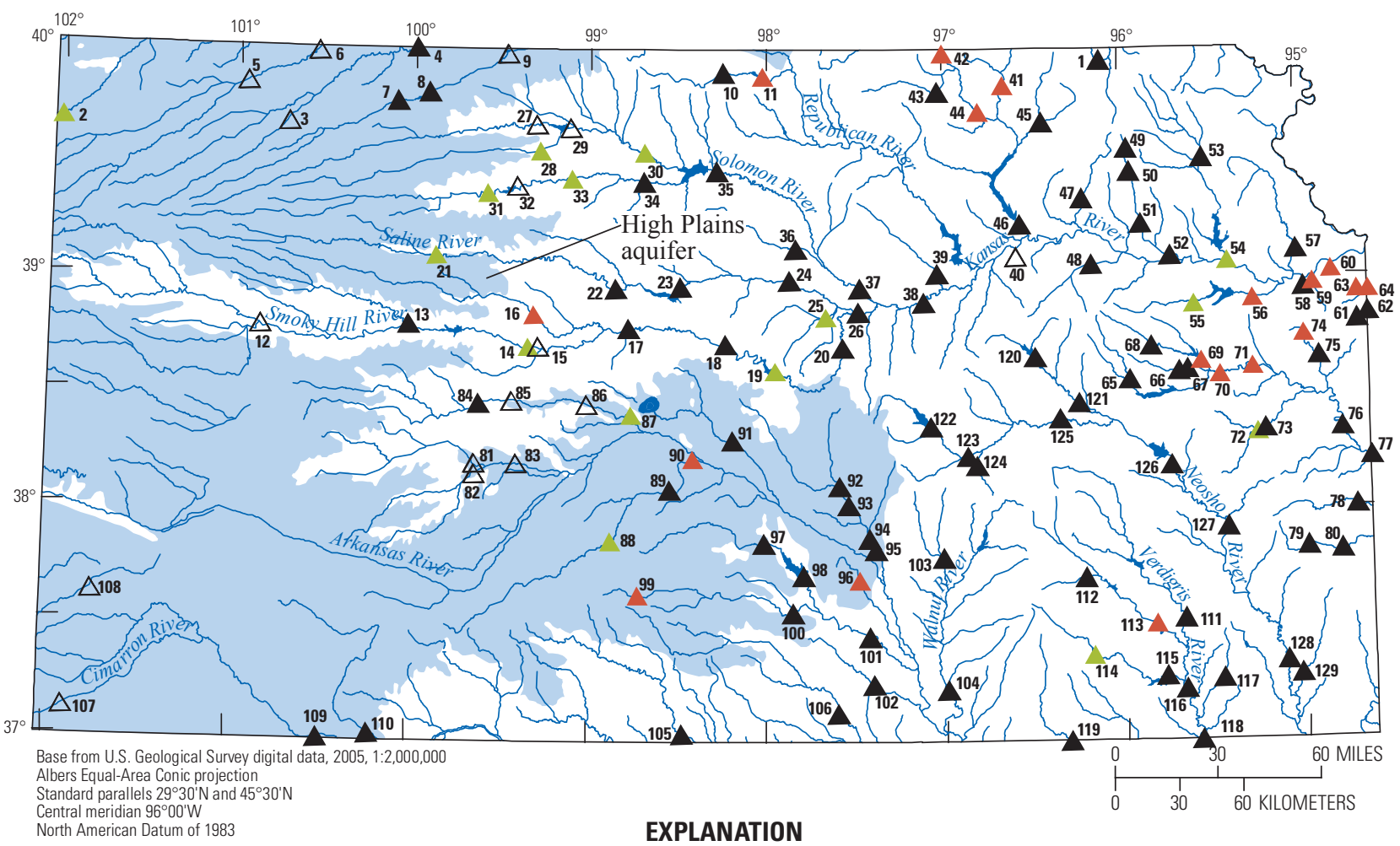

U.S. Geological Survey streamgage and identifier (table 2)—Average duration of flow pulses less than the 25th percentile

${ }^{113}$ Diminished flow condition

$114 \triangle$ Inflated flow condition

105 Minimally altered flow condition

${ }^{107} \triangle$ Not computed due to absence of flow

Figure 19. Condition of the average duration of flow pulses less than the 25th percentile metric for 129 streamgages in Kansas. 


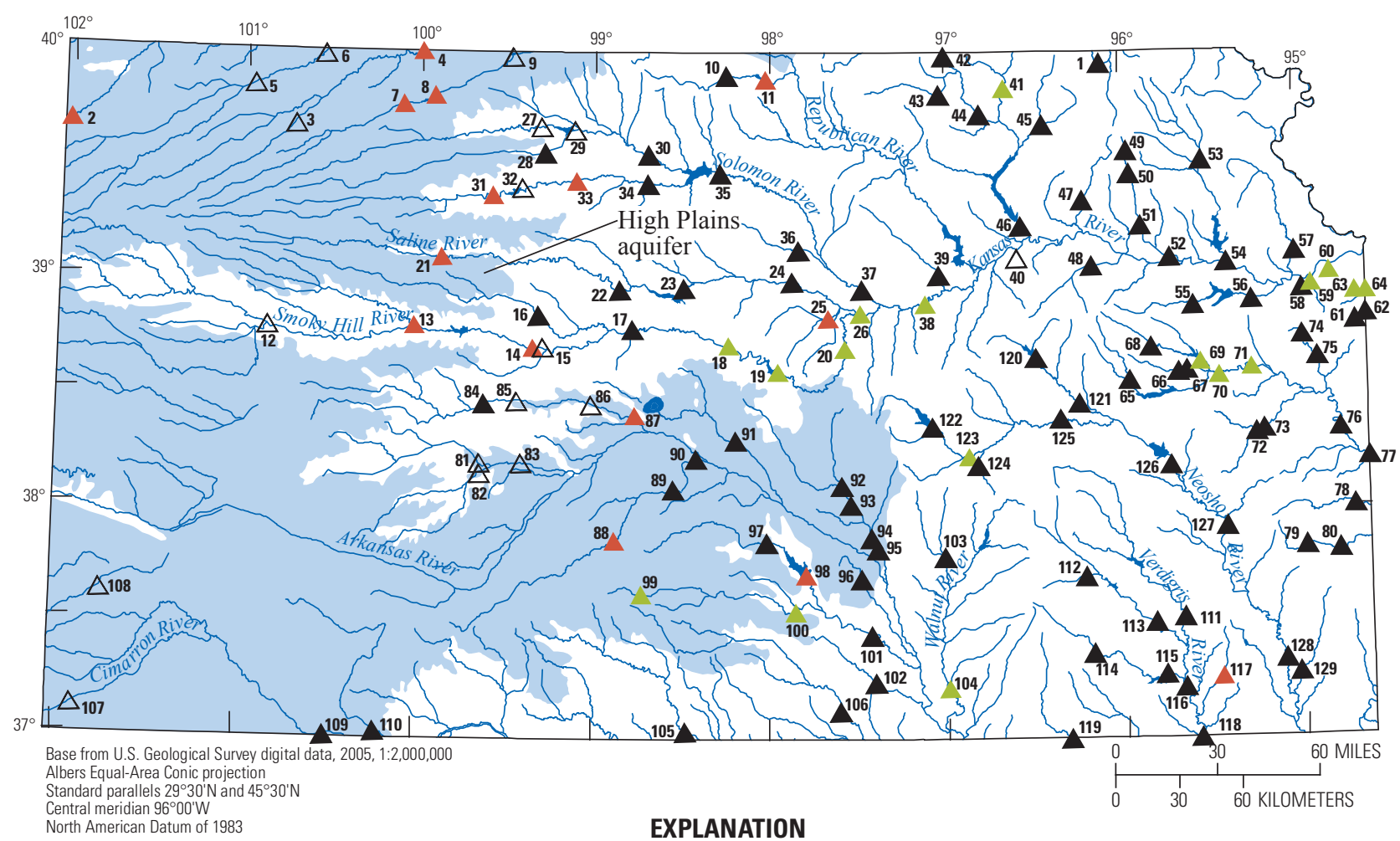

U.S. Geological Survey streamgage and identifier (table 2)-Average flow of pulses less than the 25th percentile, normalized by drainage area

${ }^{117} \triangle$ Diminished flow condition

$104 \triangle$ Inflated flow condition

110 Minimally altered flow condition

${ }^{107} \triangle$ Not computed due to absence of flow

Figure 20. Condition of the average magnitude of flow pulses less than the 25th percentile metric for 129 streamgages in Kansas. 


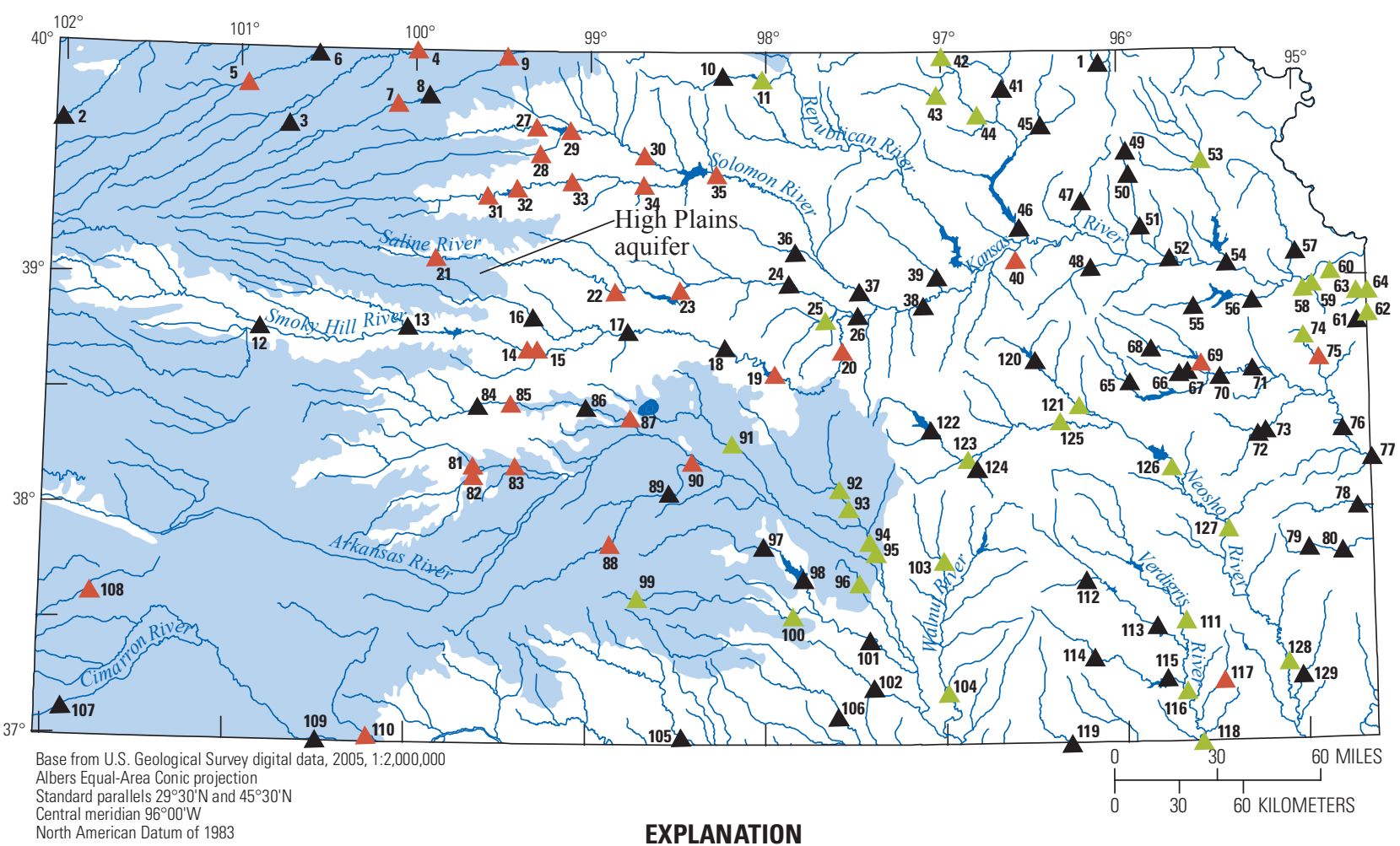

U.S. Geological Survey streamgage and identifier (table 2)—Average annual number of flow pulses greater than the 75th percentile

${ }^{110} \triangle$ Diminished flow condition $\quad 104 \triangle$ Inflated flow condition

${ }^{109}$ Minimally altered flow condition

Figure 21. Condition of the average annual number of flow pulses greater than the 75 th percentile metric for 129 streamgages in Kansas. 


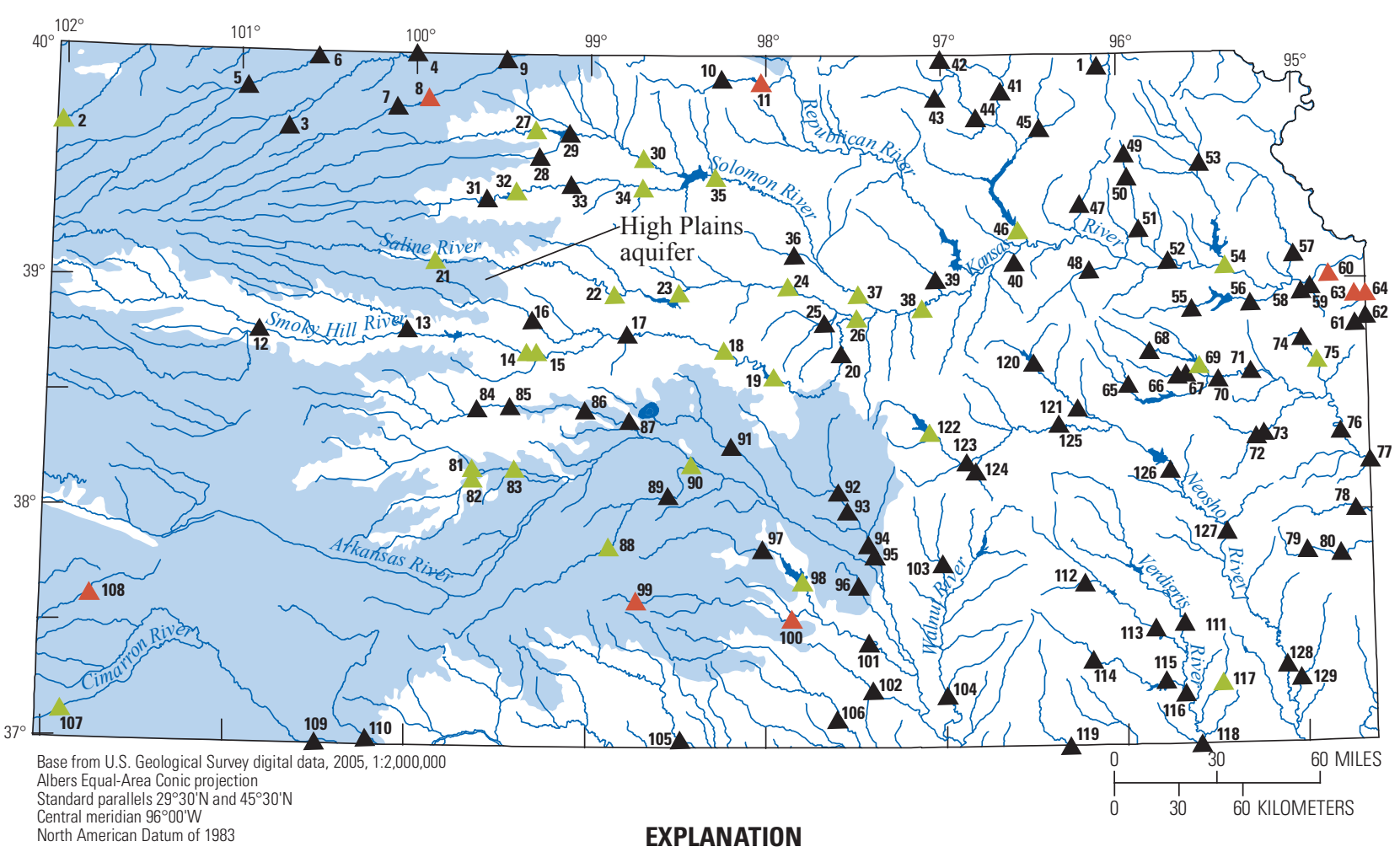

U.S. Geological Survey streamgage and identifier (table 2)—Average duration of flow pulses greater than the 75th percentile
${ }^{108}$ Diminished flow condition
$117 \triangle$ Inflated flow condition
110. Minimally altered flow condition

Figure 22. Condition of the average duration of flow pulses greater than the 75th percentile metric for 129 streamgages in Kansas. 


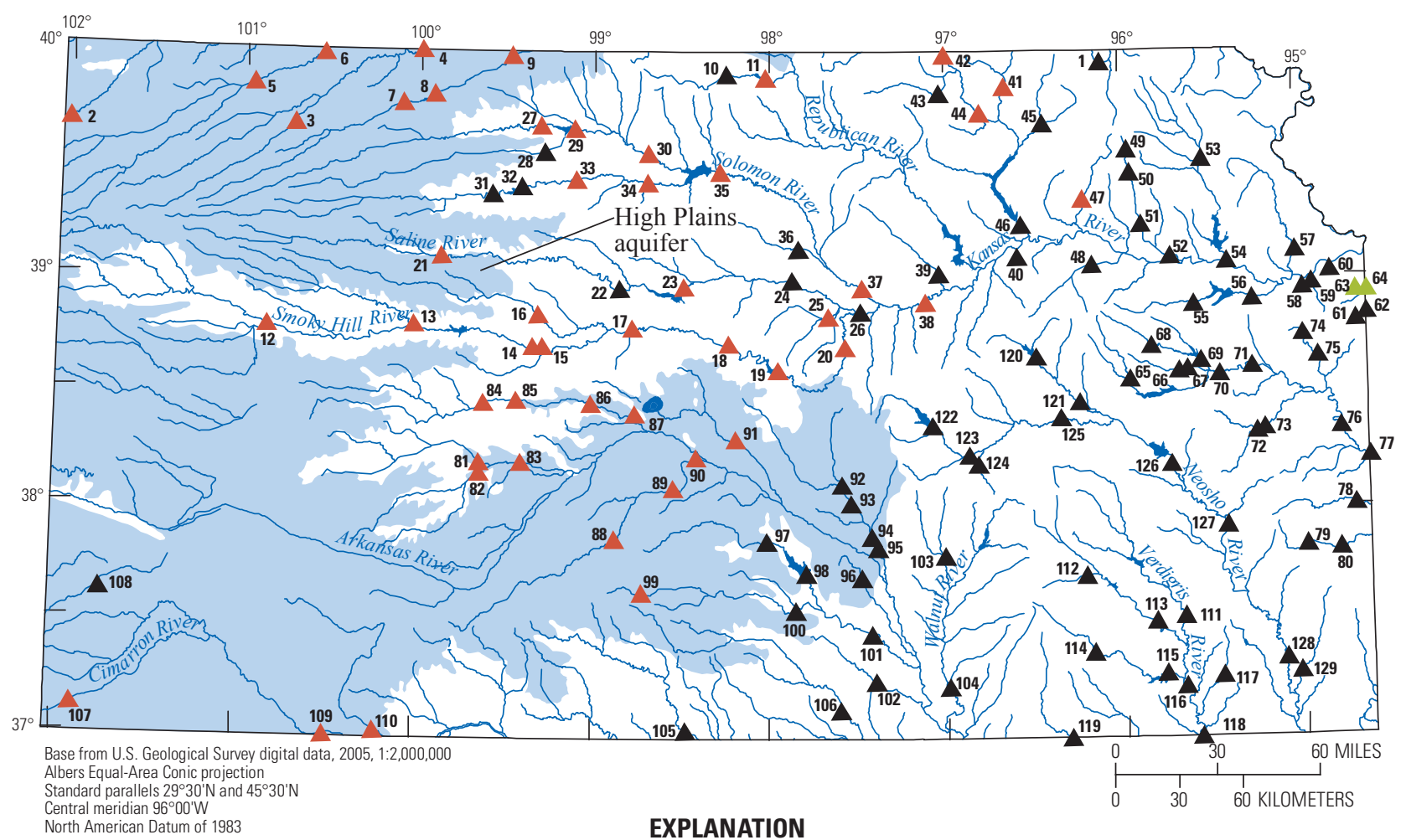

U.S. Geological Survey streamgage and identifier (table 2)—Average flow of pulses greater than the 75th percentile, normalized by drainage area

${ }^{109} \triangle$ Diminished flow condition

$64 \triangle$ Inflated flow condition

${ }_{105}$ Minimally altered flow condition

Figure 23. Condition of the average magnitude of flow pulses greater than the 75 th percentile metric for 129 streamgages in Kansas. 


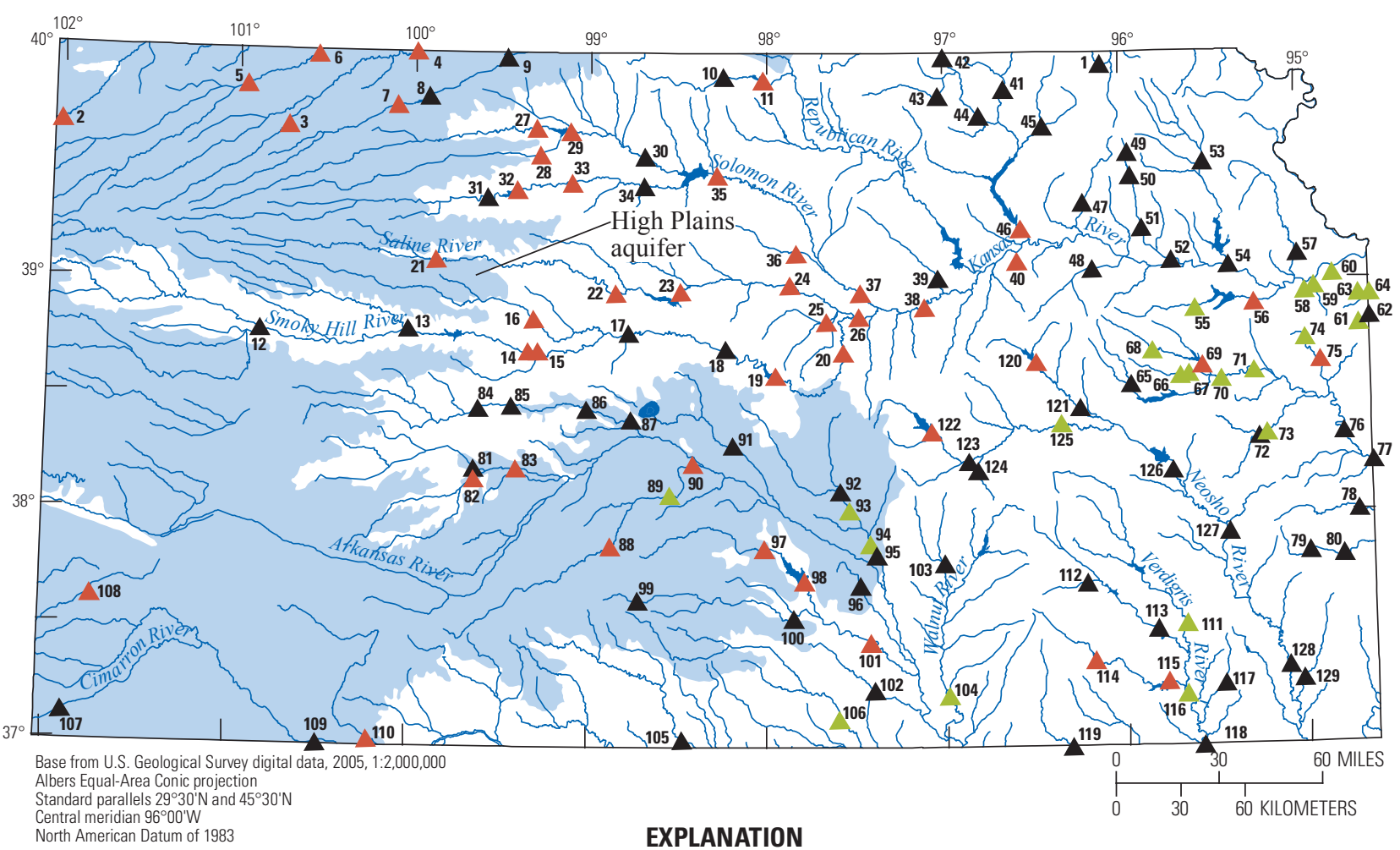

U.S. Geological Survey streamgage and identifier (table 2)—Average annual number of flow pulses greater than the 90th percentile

110 Diminished flow condition

106 Inflated flow condition

105 Minimally altered flow condition

Figure 24. Condition of the average annual number of flow pulses greater than the 90th percentile metric for 129 streamgages in Kansas. 


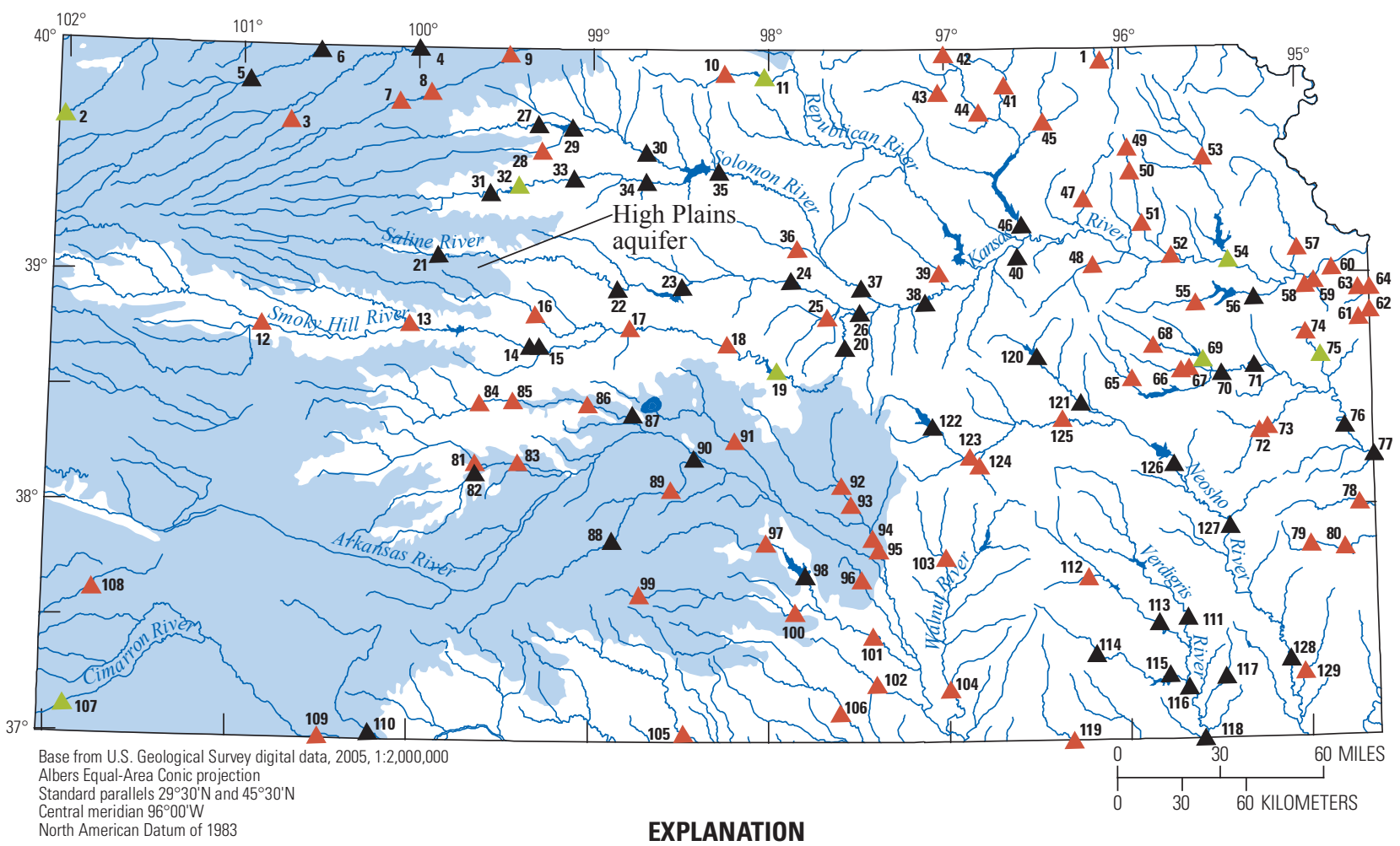

U.S. Geological Survey streamgage and identifier (table 2)—Average duration of flow pulses greater than the 90th percentile

105 Diminished flow condition $107 \triangle$ Inflated flow condition

110 Minimally altered flow condition

Figure 25. Condition of the average duration of flow pulses greater than the 90th percentile metric for 129 streamgages in Kansas. 


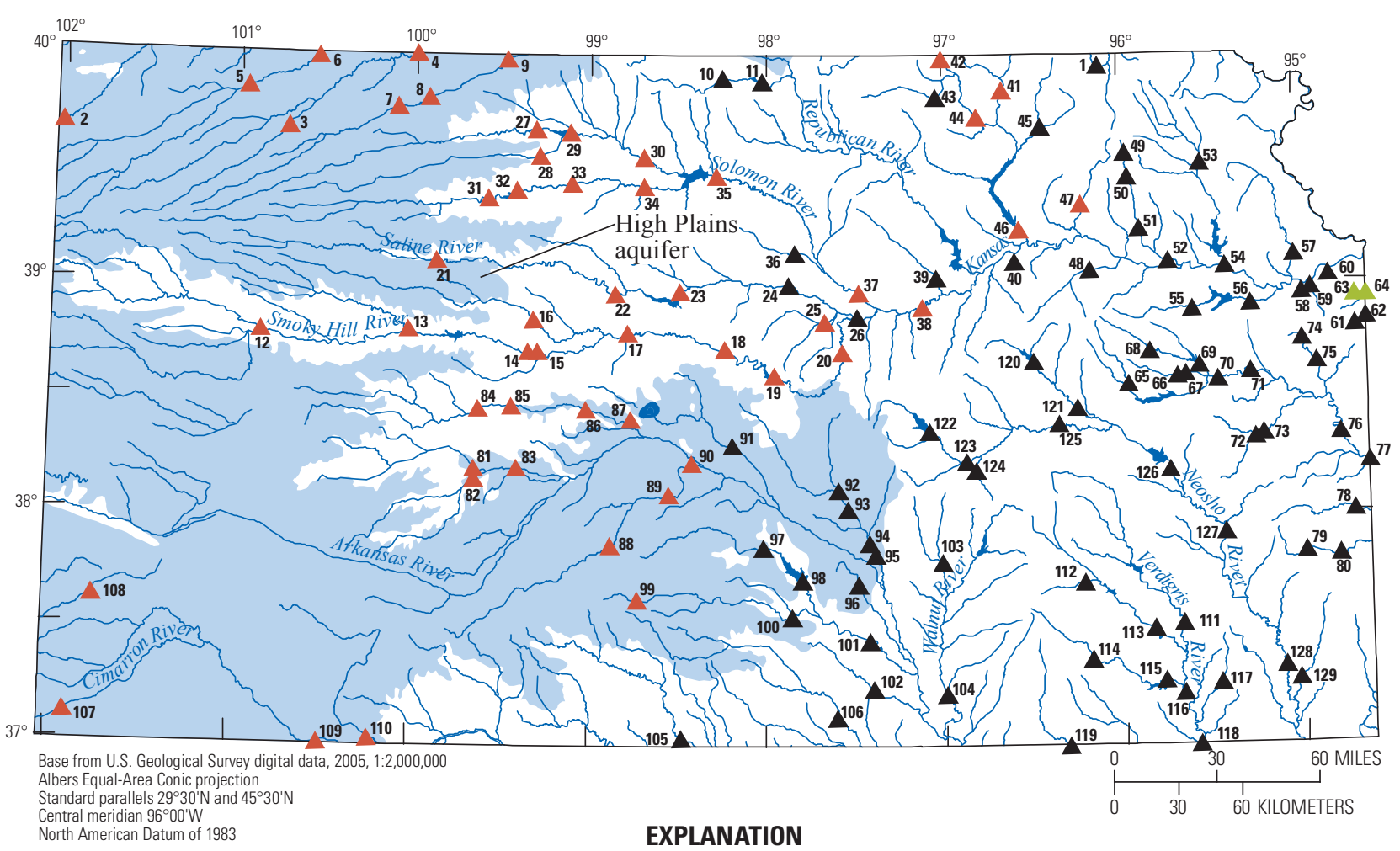

U.S. Geological Survey streamgage and identifier (table 2)—Average flow of pulses greater than the 90th percentile, normalized by drainage area

110 Diminished flow condition

$64 \triangle$ Inflated flow condition

105 Minimally altered flow condition

Figure 26. Condition of the average magnitude of flow pulses greater than the 90th percentile metric for 129 streamgages in Kansas. 


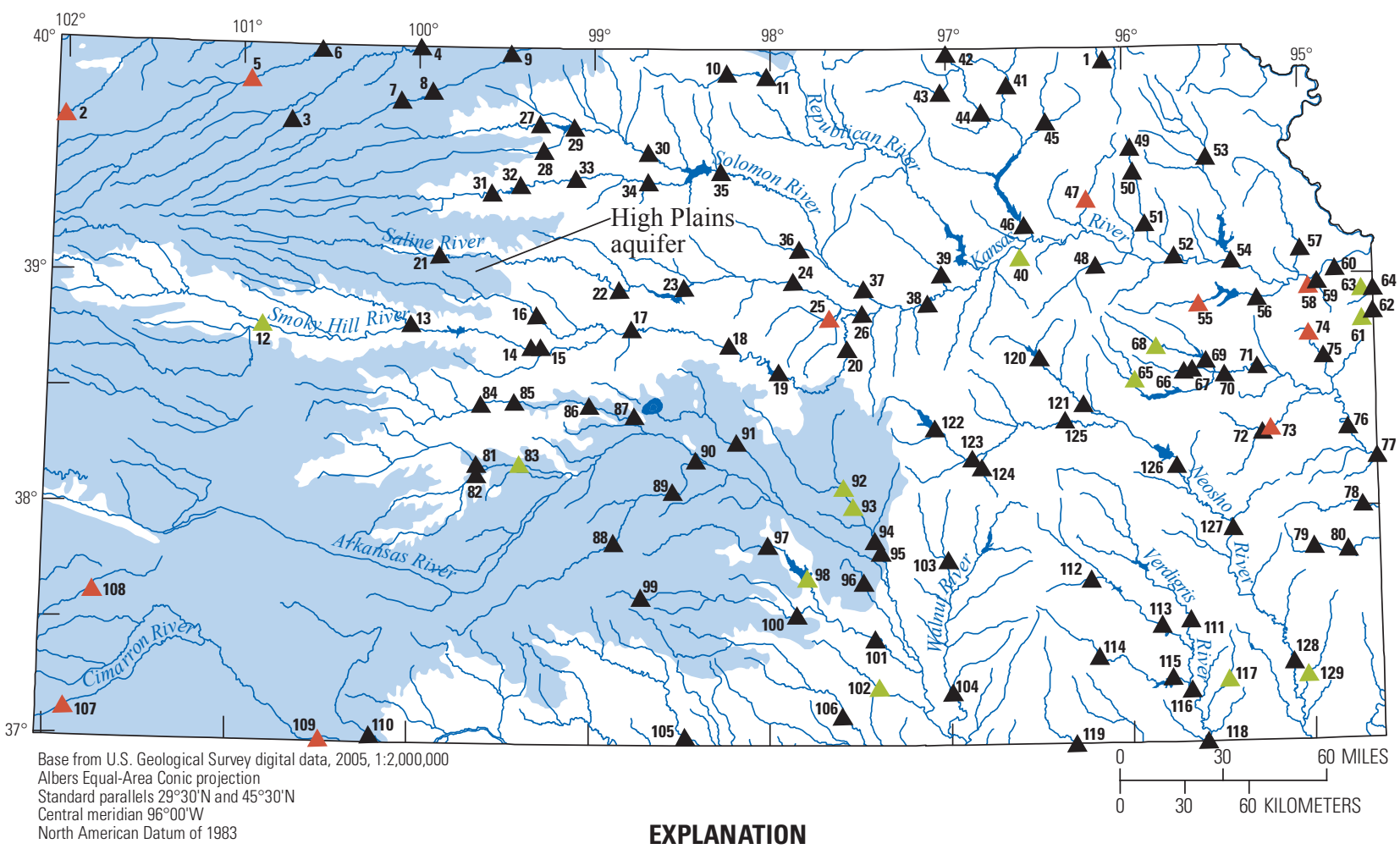

U.S. Geological Survey streamgage and identifier (table 2)Percentage of flow that is base flow

${ }^{109} \triangle$ Diminished flow condition $102 \Delta$ Inflated flow condition

105 Minimally altered flow condition

Figure 27. Condition of the percentage of flow that is base flow metric for 129 streamgages in Kansas. 


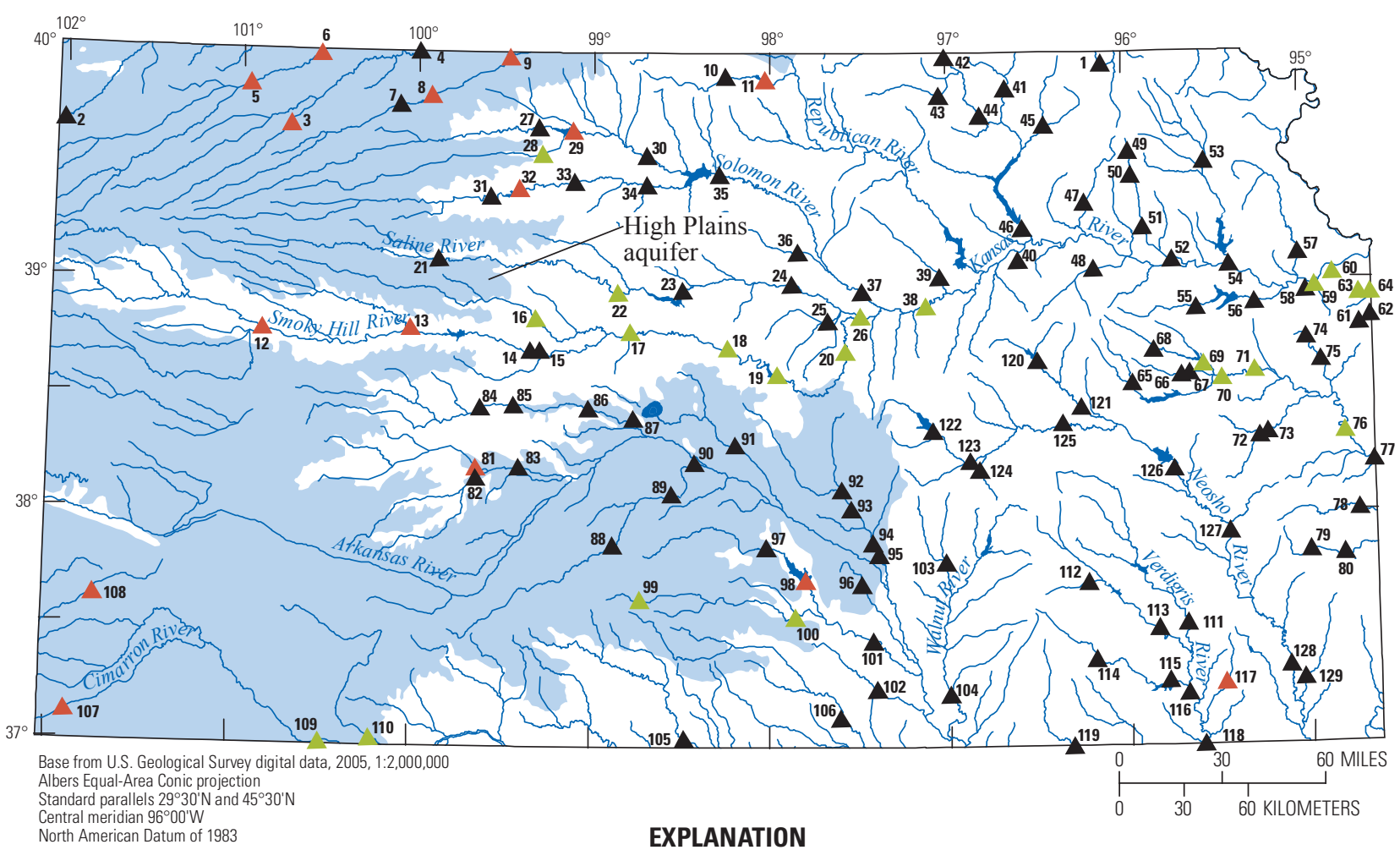

U.S. Geological Survey streamgage and identifier (table 2)10th percentile flow normalized by drainage area

$107 \triangle$ Diminished flow condition

99 Inflated flow condition

105 Minimally altered flow condition

Figure 28. Condition of the 10th percentile flow normalized by drainage area metric for 129 streamgages in Kansas. 


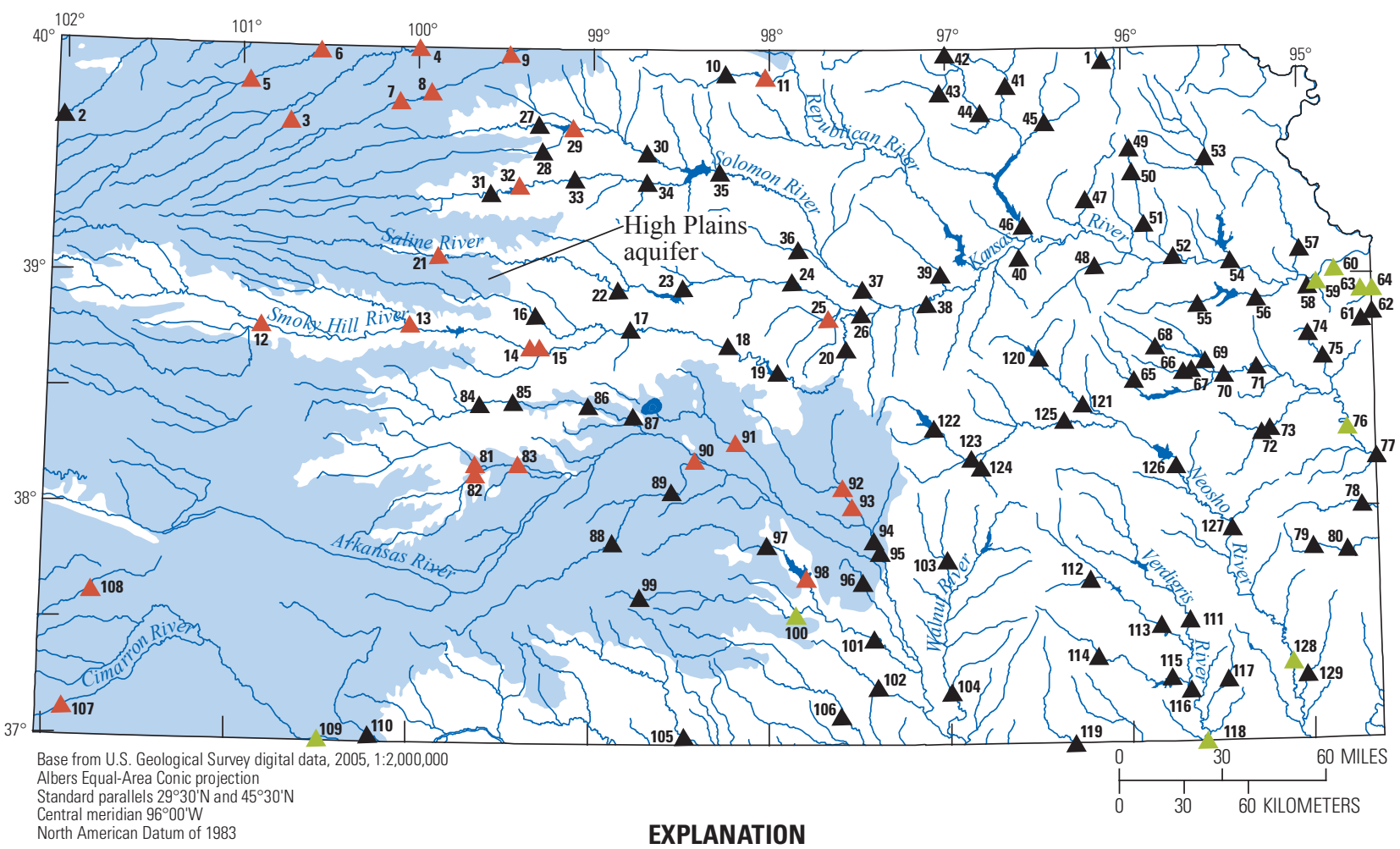

U.S. Geological Survey streamgage and identifier (table 2)Median annual flow normalized by drainage area

${ }^{107} \triangle$ Diminished flow condition $\quad 100 \Delta$ Inflated flow condition

105 Minimally altered flow condition

Figure 29. Condition of the median flow normalized by drainage area metric for 129 streamgages in Kansas. 


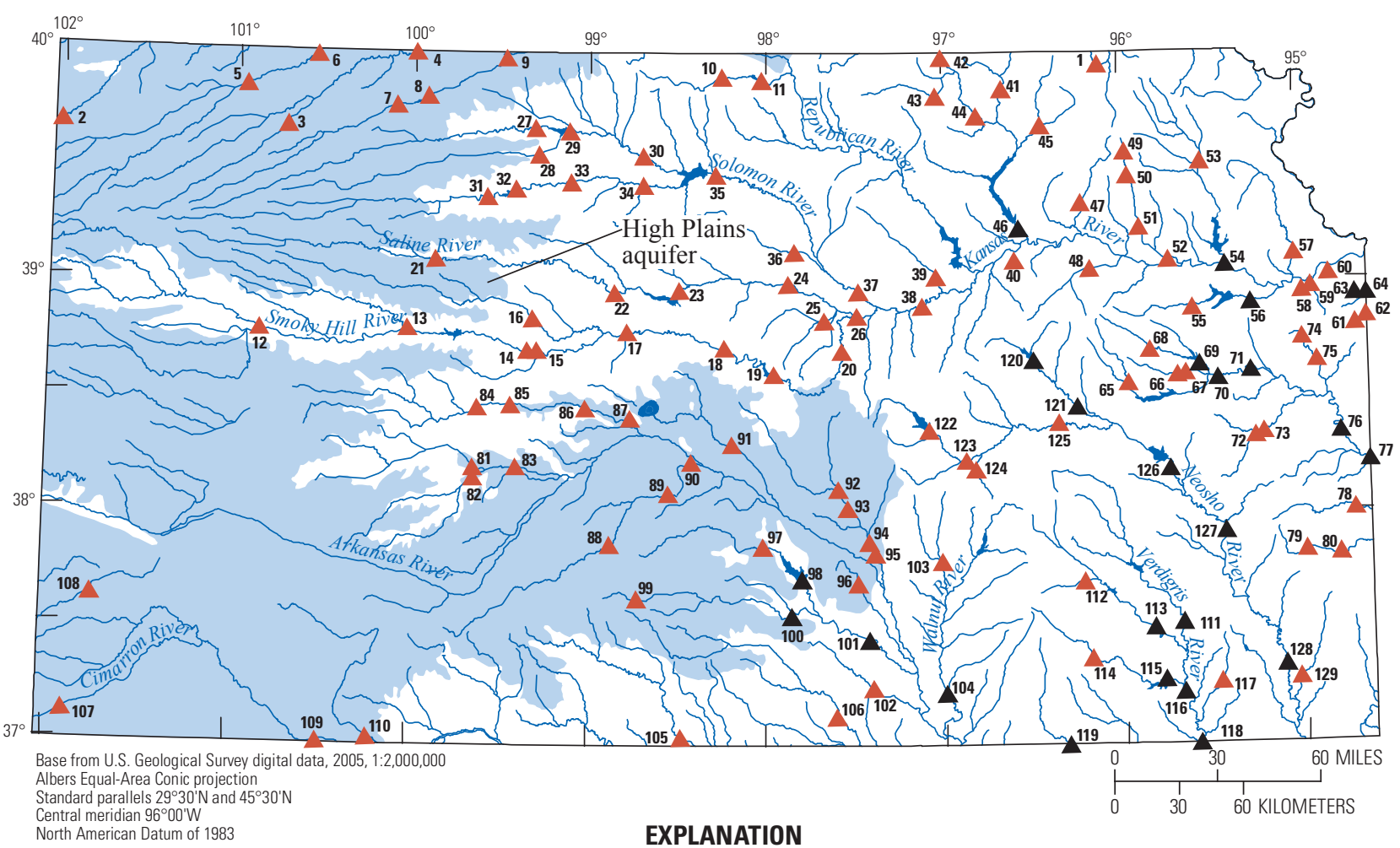

U.S. Geological Survey streamgage and identifier (table 2)90th percentile flow normalized by drainage area

${ }^{107} \triangle$ Diminished flow condition $\quad{ }^{100} \Delta$ Minimally altered flow condition

Figure 30. Condition of the 90th percentile flow normalized by drainage area metric for 129 streamgages in Kansas. 


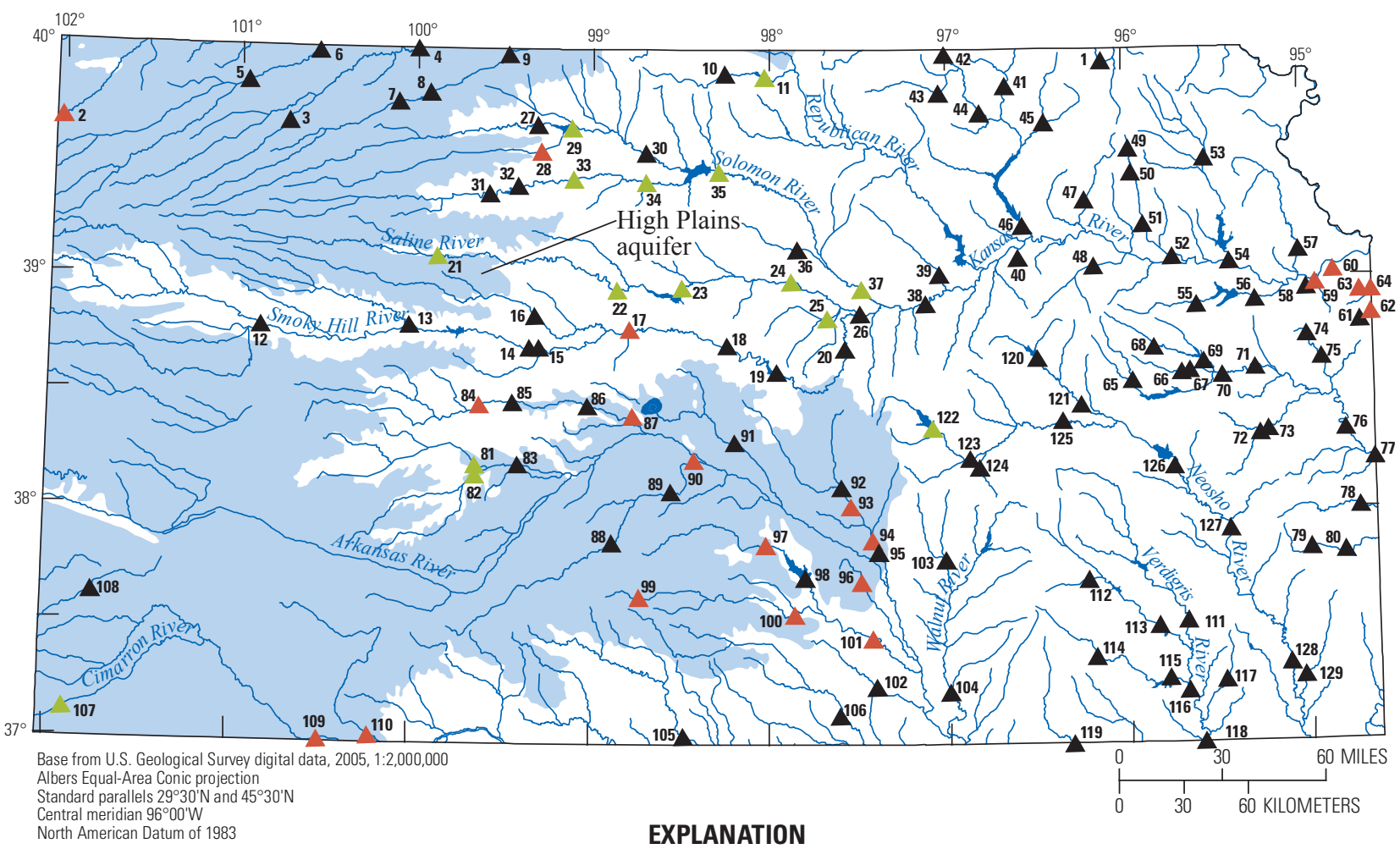

U.S. Geological Survey streamgage and identifier (table 2)Coefficient of variation of daily flows

${ }^{109} \Delta$ Diminished flow condition $122 \Delta$ Inflated flow condition

105 Minimally altered flow condition

Figure 31. Condition of the coefficient of variation of daily flows metric for 129 streamgages in Kansas. 
Appendix 1. Observed/Expected (0/E) Ratio Values for Streamflow Metrics Assessed in This Study 
Table 1-1. Observed/Expected (O/E) ratio values for the January, February, March, and April flow metrics assessed in this study.

[Diminished values are shown in bold. Inflated values are shown in italics. USGS, U.S. Geological Survey]

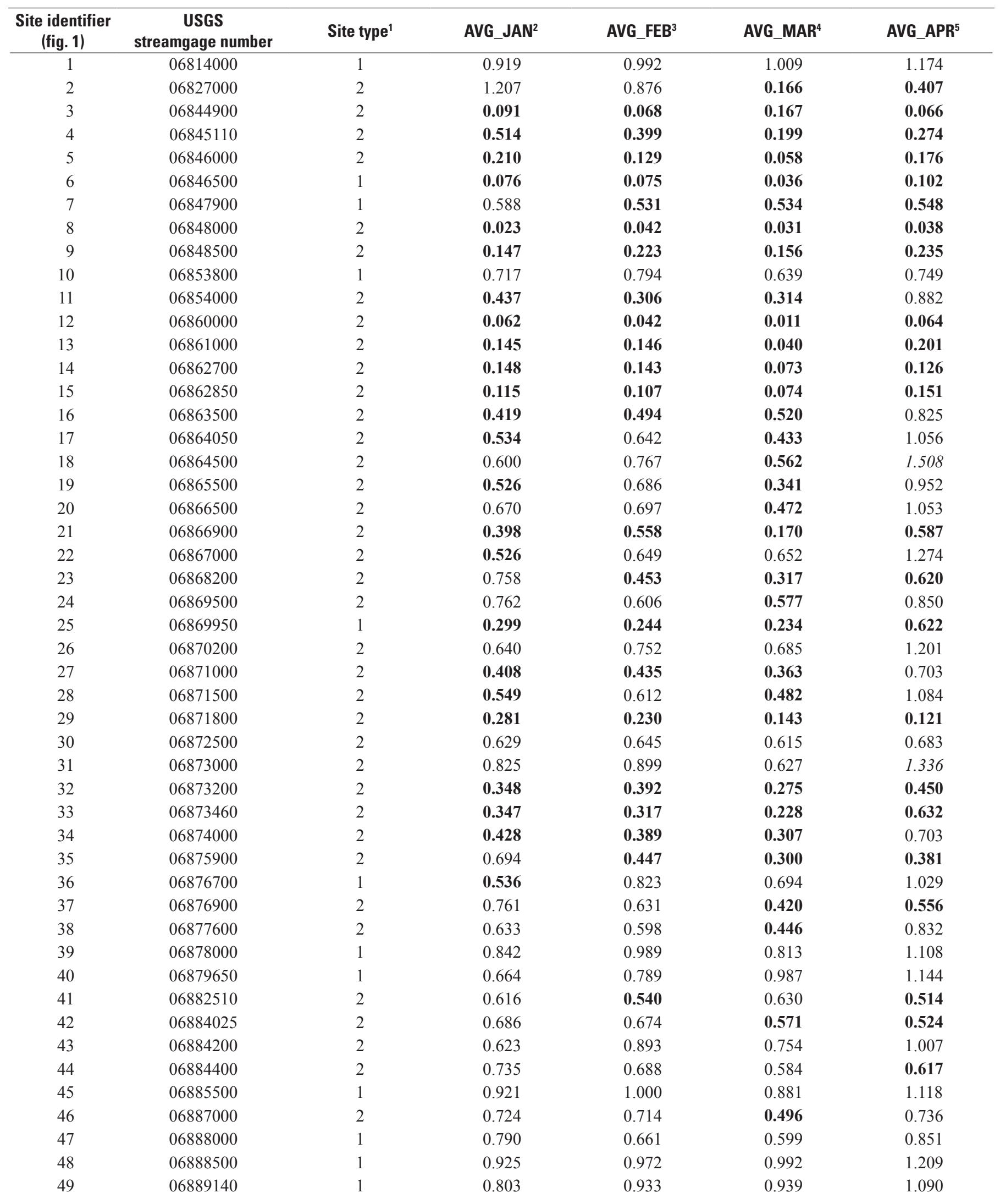


Table 1-1. Observed/Expected (0/E) ratio values for the January, February, March, and April flow metrics assessed in this study.Continued

[Diminished values are shown in bold. Inflated values are shown in italics. USGS, U.S. Geological Survey]

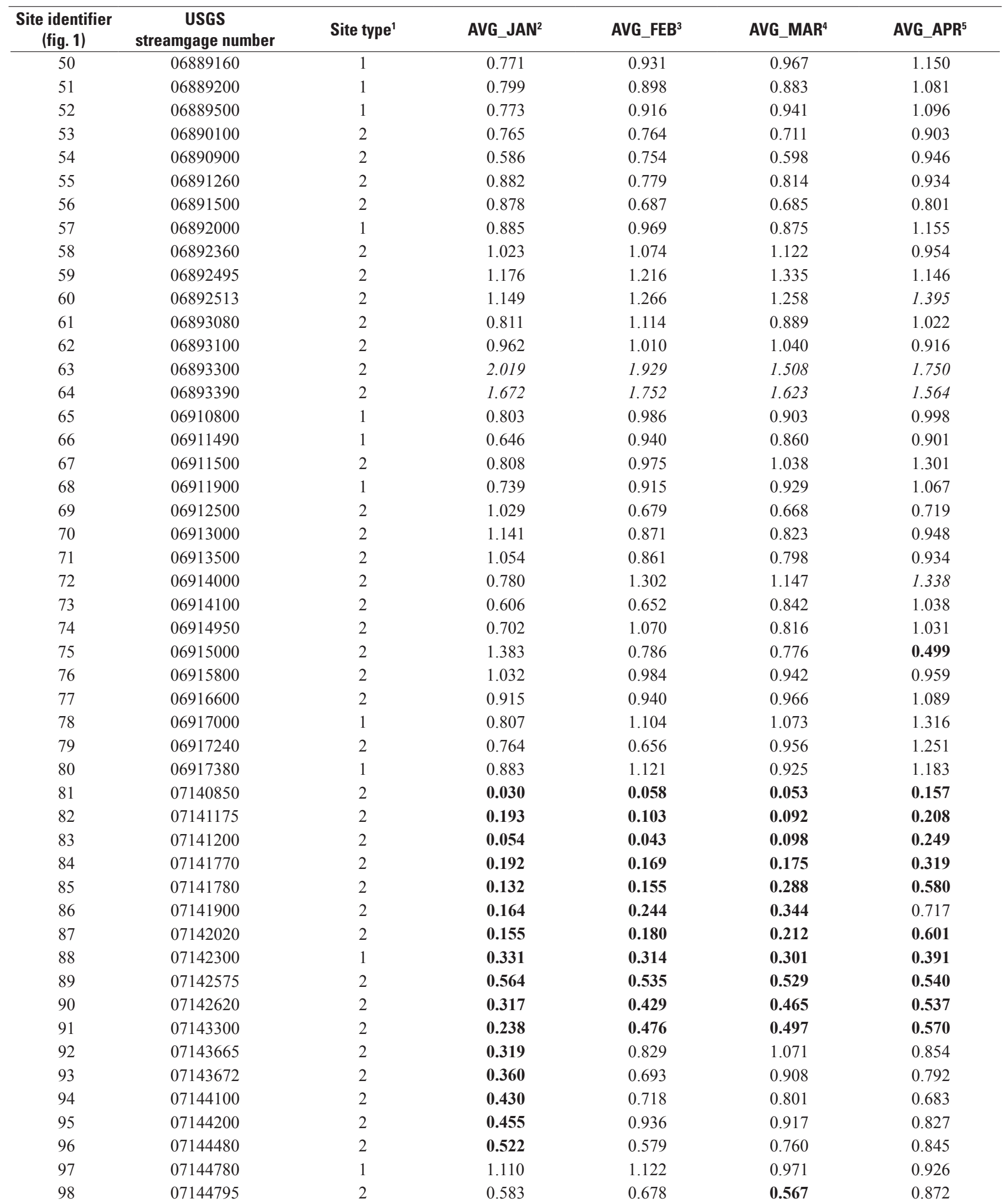


Table 1-1. Observed/Expected (0/E) ratio values for the January, February, March, and April flow metrics assessed in this study.Continued

[Diminished values are shown in bold. Inflated values are shown in italics. USGS, U.S. Geological Survey]

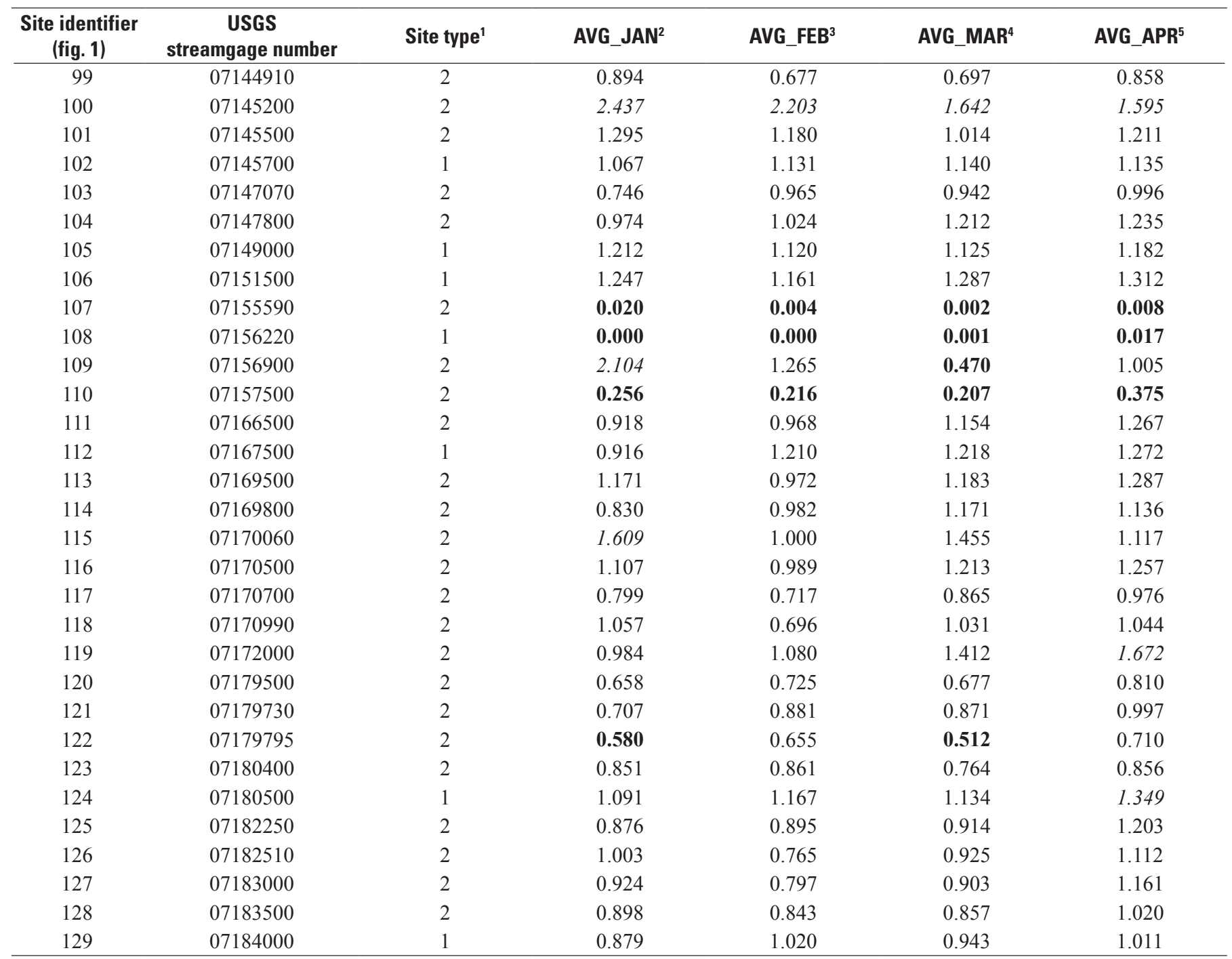

'Site type "1" indicates a reference (least-disturbed) site and site type "2" indicates a nonreference site (Falcone and others, 2010).

${ }^{2}$ Mean January flow normalized by drainage area. Tenth percentile error bound is 0.580 . Ninetieth percentile error bound is 1.550 .

${ }^{3}$ Mean February flow normalized by drainage area. Tenth percentile error bound is 0.560 . Ninetieth percentile error bound is 1.420 .

${ }^{4}$ Mean March flow normalized by drainage area. Tenth percentile error bound is 0.580 . Ninetieth percentile error bound is 1.470 .

${ }^{5}$ Mean April flow normalized by drainage area. Tenth percentile error bound is 0.660 . Ninetieth percentile error bound is 1.330 . 
Table 1-2. Observed/Expected (O/E) ratio values for the May, June, July, and August flow metrics assessed in this study.

[Diminished values are shown in bold. Inflated values are shown in italics. USGS, U.S. Geological Survey]

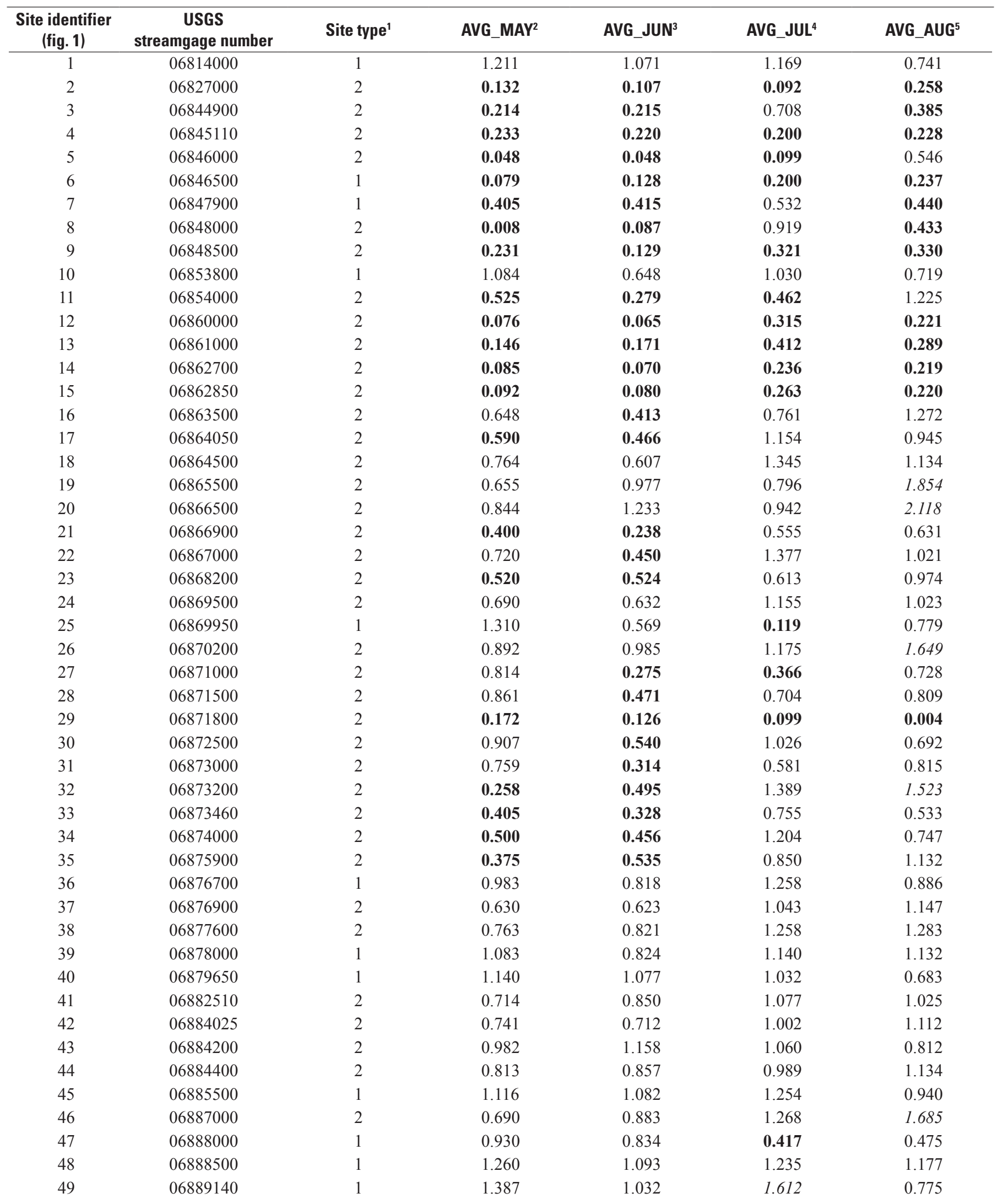


Table 1-2. Observed/Expected (O/E) ratio values for the May, June, July, and August flow metrics assessed in this study.-Continued [Diminished values are shown in bold. Inflated values are shown in italics. USGS, U.S. Geological Survey]

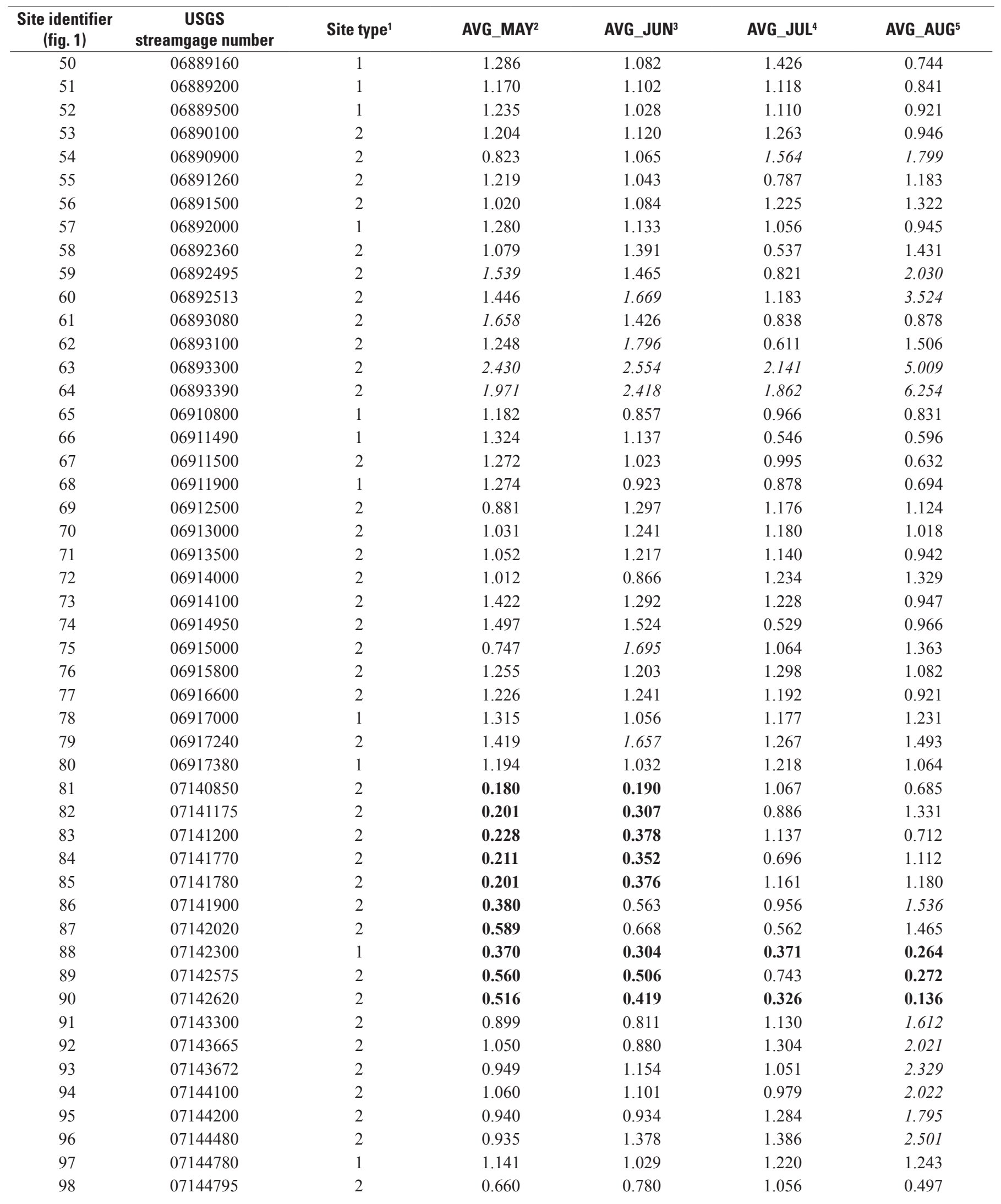


Table 1-2. Observed/Expected (0/E) ratio values for the May, June, July, and August flow metrics assessed in this study.-Continued [Diminished values are shown in bold. Inflated values are shown in italics. USGS, U.S. Geological Survey]

\begin{tabular}{|c|c|c|c|c|c|c|}
\hline $\begin{array}{l}\text { Site identifier } \\
\text { (fig. 1) }\end{array}$ & $\begin{array}{c}\text { USGS } \\
\text { streamgage number }\end{array}$ & Site type ${ }^{1}$ & AVG_MAY ${ }^{2}$ & AVG_JUN ${ }^{3}$ & AVG_JUL ${ }^{4}$ & AVG_AUG ${ }^{5}$ \\
\hline 99 & 07144910 & 2 & 0.901 & 0.734 & 1.294 & 1.750 \\
\hline 100 & 07145200 & 2 & 1.511 & 1.310 & 1.686 & 2.176 \\
\hline 101 & 07145500 & 2 & 1.029 & 1.047 & 1.264 & 1.305 \\
\hline 102 & 07145700 & 1 & 1.172 & 1.305 & 1.234 & 1.612 \\
\hline 103 & 07147070 & 2 & 1.031 & 1.276 & 1.242 & 2.043 \\
\hline 104 & 07147800 & 2 & 1.197 & 1.307 & 1.191 & 1.597 \\
\hline 105 & 07149000 & 1 & 1.137 & 1.039 & 1.387 & 1.225 \\
\hline 106 & 07151500 & 1 & 1.106 & 1.153 & 1.103 & 1.284 \\
\hline 107 & 07155590 & 2 & 0.161 & 0.065 & 0.044 & 0.179 \\
\hline 108 & 07156220 & 1 & 0.146 & 0.017 & 1.016 & 0.920 \\
\hline 109 & 07156900 & 2 & 0.337 & 0.136 & 0.179 & 0.152 \\
\hline 110 & 07157500 & 2 & 0.245 & 0.221 & 0.275 & 0.279 \\
\hline 111 & 07166500 & 2 & 1.191 & 1.254 & 1.054 & 1.624 \\
\hline 112 & 07167500 & 1 & 1.261 & 1.346 & 0.822 & 1.374 \\
\hline 113 & 07169500 & 2 & 1.147 & 1.143 & 1.419 & 1.700 \\
\hline 114 & 07169800 & 2 & 1.272 & 1.338 & 0.712 & 0.681 \\
\hline 115 & 07170060 & 2 & 0.940 & 1.424 & 1.058 & 0.923 \\
\hline 116 & 07170500 & 2 & 1.234 & 1.280 & 1.340 & 1.756 \\
\hline 117 & 07170700 & 2 & 1.312 & 1.338 & 0.931 & 0.958 \\
\hline 118 & 07170990 & 2 & 1.658 & 1.534 & 2.124 & 2.922 \\
\hline 119 & 07172000 & 2 & 1.852 & 2.070 & 1.019 & 0.830 \\
\hline 120 & 07179500 & 2 & 0.847 & 1.010 & 0.935 & 1.376 \\
\hline 121 & 07179730 & 2 & 0.964 & 1.030 & 1.047 & 1.387 \\
\hline 122 & 07179795 & 2 & 0.831 & 0.740 & 0.912 & 1.139 \\
\hline 123 & 07180400 & 2 & 0.999 & 0.960 & 1.131 & 1.422 \\
\hline 124 & 07180500 & 1 & 1.277 & 1.136 & 1.118 & 1.665 \\
\hline 125 & 07182250 & 2 & 1.067 & 0.975 & 0.967 & 1.751 \\
\hline 126 & 07182510 & 2 & 0.905 & 1.208 & 1.202 & 1.999 \\
\hline 127 & 07183000 & 2 & 0.878 & 1.067 & 1.159 & 1.919 \\
\hline 128 & 07183500 & 2 & 0.992 & 1.080 & 1.236 & 1.690 \\
\hline 129 & 07184000 & 1 & 1.284 & 1.220 & 1.323 & 1.348 \\
\hline
\end{tabular}

${ }^{1}$ Site type " 1 " indicates a reference (least-disturbed) site and site type " 2 " indicates a nonreference site (Falcone and others, 2010).

${ }^{2}$ Mean May flow normalized by drainage area. Tenth percentile error bound is 0.600 . Ninetieth percentile error bound is 1.530 .

${ }^{3}$ Mean June flow normalized by drainage area. Tenth percentile error bound is 0.550 . Ninetieth percentile error bound is 1.600.

${ }^{4}$ Mean July flow normalized by drainage area. Tenth percentile error bound is 0.490 . Ninetieth percentile error bound is 1.510 .

${ }^{5}$ Mean August flow normalized by drainage area. Tenth percentile error bound is 0.440 . Ninetieth percentile error bound is 1.510 . 
Table 1-3. Observed/Expected (0/E) ratio values for the September, October, November, and December flow metrics assessed in this study.

[Diminished values are shown in bold. Inflated values are shown in italics. USGS, U.S. Geological Survey]

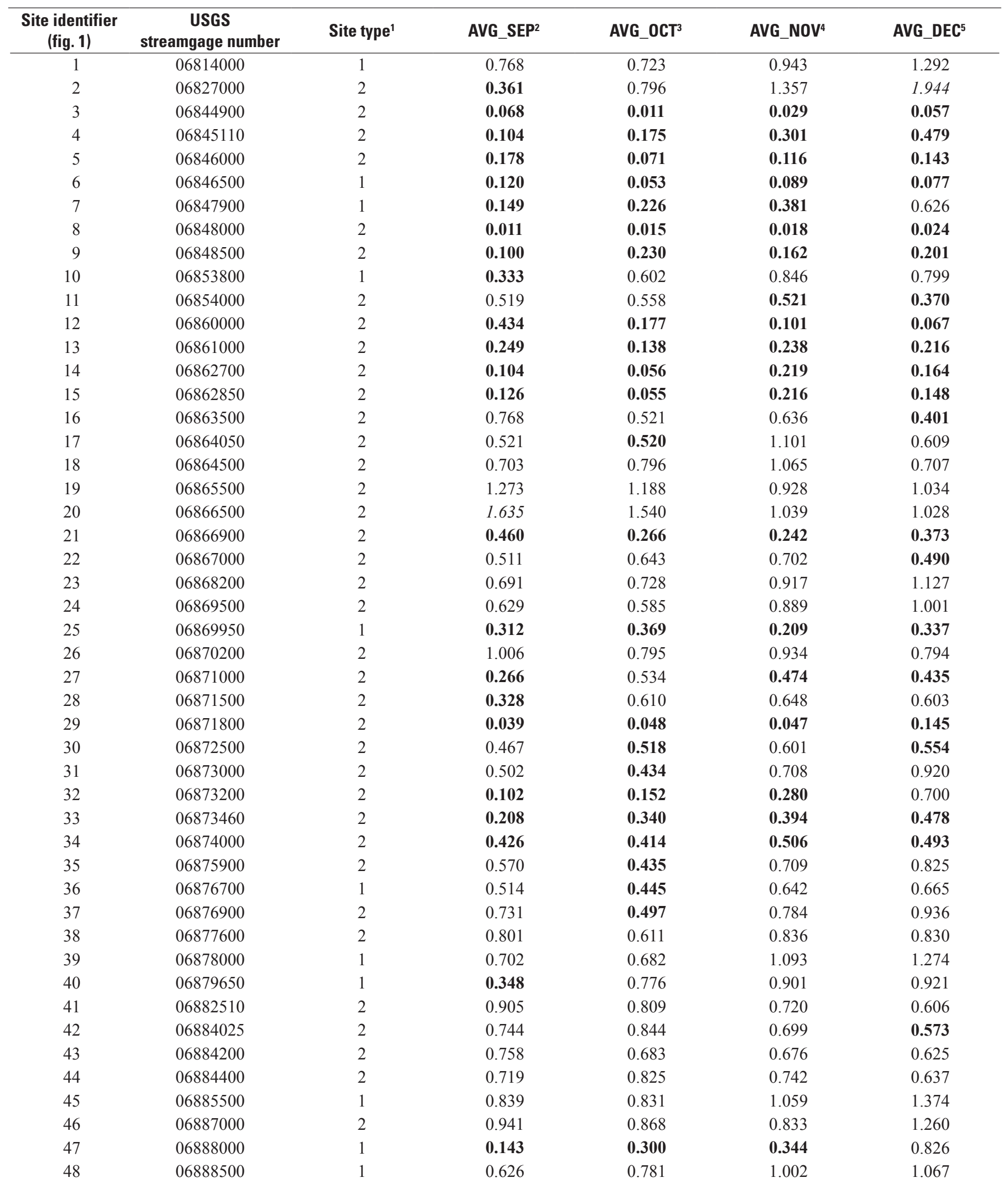


Table 1-3. Observed/Expected (0/E) ratio values for the September, October, November, and December flow metrics assessed in this study.-Continued

[Diminished values are shown in bold. Inflated values are shown in italics. USGS, U.S. Geological Survey]

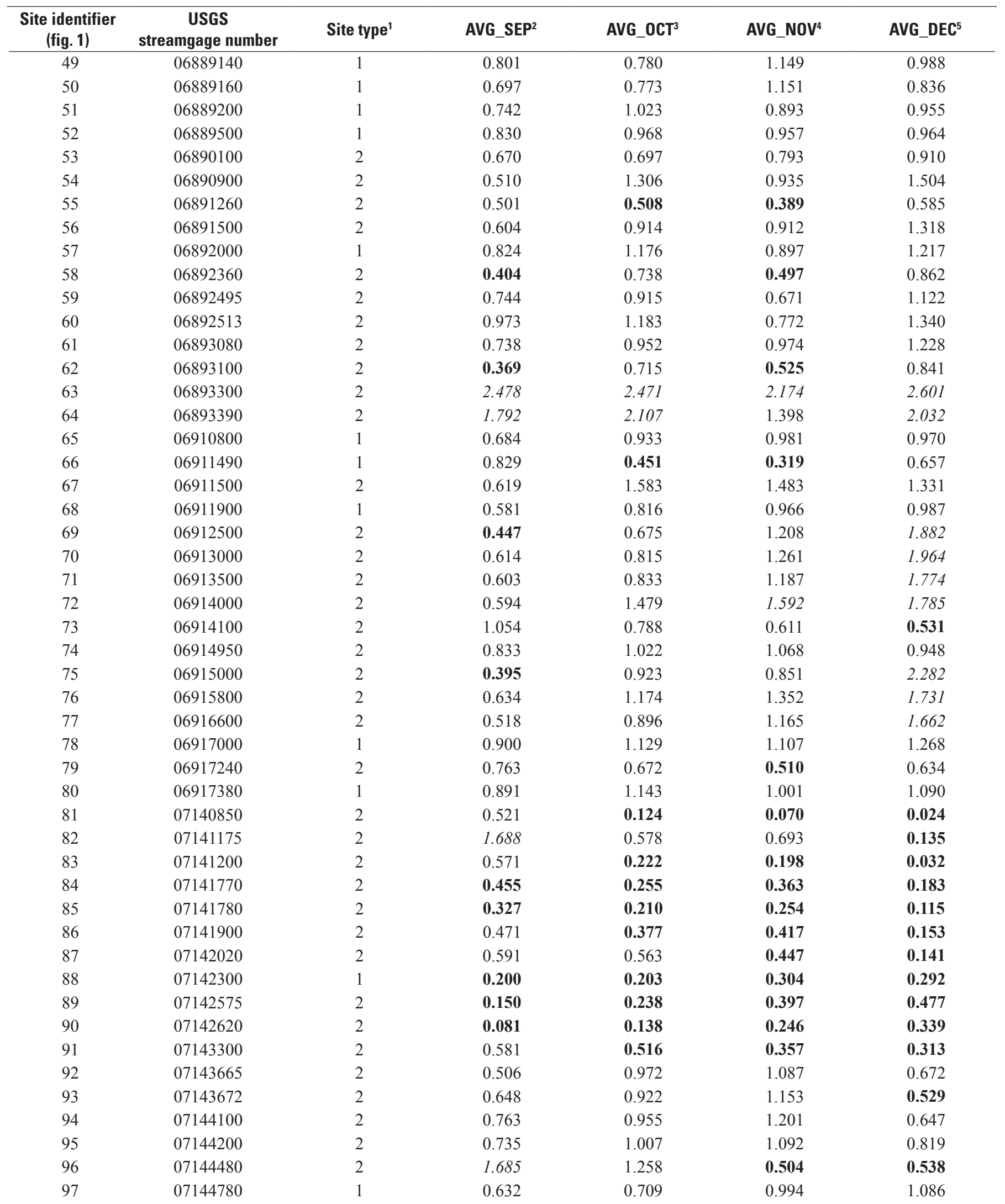


Table 1-3. Observed/Expected (0/E) ratio values for the September, October, November, and December flow metrics assessed in this study.-Continued

[Diminished values are shown in bold. Inflated values are shown in italics. USGS, U.S. Geological Survey]

\begin{tabular}{|c|c|c|c|c|c|c|}
\hline $\begin{array}{l}\text { Site identifier } \\
\text { (fig. 1) }\end{array}$ & $\begin{array}{c}\text { USGS } \\
\text { streamgage number }\end{array}$ & Site type ${ }^{1}$ & AVG_SEP2 & AVG_OCT ${ }^{3}$ & AVG_NOV ${ }^{4}$ & AVG_DEC \\
\hline 98 & 07144795 & 2 & 0.415 & 0.526 & 0.554 & 0.434 \\
\hline 99 & 07144910 & 2 & 0.852 & 0.827 & 0.881 & 0.950 \\
\hline 100 & 07145200 & 2 & 1.697 & 1.815 & 2.431 & 2.656 \\
\hline 101 & 07145500 & 2 & 1.027 & 1.145 & 1.531 & 1.320 \\
\hline 102 & 07145700 & 1 & 1.105 & 1.107 & 1.234 & 1.263 \\
\hline 103 & 07147070 & 2 & 1.024 & 1.293 & 1.527 & 1.253 \\
\hline 104 & 07147800 & 2 & 1.122 & 1.025 & 1.450 & 1.246 \\
\hline 105 & 07149000 & 1 & 0.969 & 0.974 & 1.205 & 1.243 \\
\hline 106 & 07151500 & 1 & 1.027 & 1.175 & 1.293 & 1.389 \\
\hline 107 & 07155590 & 2 & 0.046 & 0.001 & 0.004 & 0.019 \\
\hline 108 & 07156220 & 1 & 0.585 & 0.342 & 0.001 & 0.000 \\
\hline 109 & 07156900 & 2 & 0.457 & 1.051 & 2.271 & 3.526 \\
\hline 110 & 07157500 & 2 & 0.265 & 0.465 & 0.462 & 0.309 \\
\hline 111 & 07166500 & 2 & 0.839 & 0.967 & 1.186 & 1.377 \\
\hline 112 & 07167500 & 1 & 0.720 & 0.929 & 1.138 & 1.176 \\
\hline 113 & 07169500 & 2 & 0.931 & 0.998 & 1.126 & 1.472 \\
\hline 114 & 07169800 & 2 & 0.454 & 0.886 & 0.955 & 1.140 \\
\hline 115 & 07170060 & 2 & 0.283 & 1.513 & 1.198 & 1.405 \\
\hline 116 & 07170500 & 2 & 0.789 & 1.076 & 1.119 & 1.369 \\
\hline 117 & 07170700 & 2 & 0.738 & 1.148 & 0.798 & 0.734 \\
\hline 118 & 07170990 & 2 & 1.245 & 0.586 & 0.673 & 0.571 \\
\hline 119 & 07172000 & 2 & 0.505 & 1.431 & 1.094 & 1.211 \\
\hline 120 & 07179500 & 2 & 0.568 & 0.685 & 0.908 & 0.770 \\
\hline 121 & 07179730 & 2 & 0.611 & 0.725 & 0.938 & 0.848 \\
\hline 122 & 07179795 & 2 & 0.411 & 0.681 & 0.832 & 1.894 \\
\hline 123 & 07180400 & 2 & 0.899 & 0.941 & 1.406 & 1.596 \\
\hline 124 & 07180500 & 1 & 1.022 & 1.103 & 1.368 & 1.333 \\
\hline 125 & 07182250 & 2 & 0.830 & 0.932 & 1.307 & 1.181 \\
\hline 126 & 07182510 & 2 & 0.784 & 0.803 & 1.192 & 1.252 \\
\hline 127 & 07183000 & 2 & 0.865 & 0.903 & 1.169 & 1.202 \\
\hline 128 & 07183500 & 2 & 0.857 & 0.960 & 1.059 & 1.353 \\
\hline 129 & 07184000 & 1 & 1.209 & 1.335 & 0.959 & 1.146 \\
\hline
\end{tabular}

'Site type " 1 " indicates a reference (least-disturbed) site and site type "2" indicates a nonreference site (Falcone and others, 2010).

${ }^{2}$ Mean September flow normalized by drainage area. Tenth percentile error bound is 0.460 . Ninetieth percentile error bound is 1.490 .

${ }^{3}$ Mean October flow normalized by drainage area. Tenth percentile error bound is 0.520 . Ninetieth percentile error bound is 1.680 .

${ }^{4}$ Mean November flow normalized by drainage area. Tenth percentile error bound is 0.530 . Ninetieth percentile error bound is 1.560 .

${ }^{5}$ Mean December flow normalized by drainage area. Tenth percentile error bound is 0.580 . Ninetieth percentile error bound is 1.650 . 
Table 1-4. Observed/Expected (O/E) ratio values for the 10th percentile flow metrics assessed in this study.

[Diminished values are shown in bold. Inflated values are shown in italics. USGS, U.S. Geological Survey; -999, metric could not be computed]

\begin{tabular}{|c|c|c|c|c|c|}
\hline $\begin{array}{c}\text { Site identifier } \\
\text { (fig. 1) }\end{array}$ & $\begin{array}{c}\text { USGS } \\
\text { streamgage number }\end{array}$ & Site type ${ }^{1}$ & 2PUL_NO_P10 & 3PUL_LEN_P10 & ${ }^{4}$ PUL_FLOW_P10 \\
\hline 1 & 06814000 & 1 & 1.291 & 0.742 & 0.817 \\
\hline 2 & 06827000 & 2 & 1.118 & 3.225 & 0.016 \\
\hline 4 & 06845110 & 2 & 1.322 & 1.886 & 0.023 \\
\hline 5 & 06846000 & 2 & $\mathbf{0}$ & -999 & -999 \\
\hline 8 & 06848000 & 2 & $\mathbf{0}$ & -999 & -999 \\
\hline 9 & 06848500 & 2 & $\mathbf{0}$ & -999 & -999 \\
\hline 10 & 06853800 & 1 & 0.842 & 1.455 & 0.105 \\
\hline 11 & 06854000 & 2 & 1.613 & 0.498 & 0.006 \\
\hline 12 & 06860000 & 2 & $\mathbf{0}$ & -999 & -999 \\
\hline 16 & 06863500 & 2 & 4.513 & 0.750 & 0.007 \\
\hline 17 & 06864050 & 2 & 4.034 & 0.898 & 0.611 \\
\hline 18 & 06864500 & 2 & 3.315 & 1.051 & 0.994 \\
\hline 19 & 06865500 & 2 & 2.223 & 1.585 & 1.332 \\
\hline 20 & 06866500 & 2 & 3.924 & 0.638 & 2.615 \\
\hline 21 & 06866900 & 2 & $\mathbf{0}$ & -999 & -999 \\
\hline 22 & 06867000 & 2 & 3.260 & 0.845 & 0.369 \\
\hline 23 & 06868200 & 2 & 2.948 & 0.868 & 0.862 \\
\hline 24 & 06869500 & 2 & 2.191 & 0.777 & 1.963 \\
\hline 25 & 06869950 & 1 & 1.165 & 0.942 & 0.014 \\
\hline 33 & 06873460 & 2 & 2.846 & 1.060 & $\mathbf{0 . 0 3 0}$ \\
\hline 34 & 06874000 & 2 & 2.206 & 0.699 & 0.596 \\
\hline 35 & 06875900 & 2 & 1.124 & 0.775 & 0.431 \\
\hline 36 & 06876700 & 1 & 1.038 & 1.016 & 0.552 \\
\hline 37 & 06876900 & 2 & 1.901 & 0.458 & 1.690 \\
\hline 38 & 06877600 & 2 & 1.541 & 0.826 & 2.502 \\
\hline 39 & 06878000 & 1 & 1.347 & 0.702 & 1.652 \\
\hline 40 & 06879650 & 1 & 0 & -999 & -999 \\
\hline 41 & 06882510 & 2 & 1.310 & 0.941 & 1.635 \\
\hline 42 & 06884025 & 2 & 1.441 & 0.660 & 1.973 \\
\hline 43 & 06884200 & 2 & 1.699 & 0.572 & 0.536 \\
\hline 44 & 06884400 & 2 & 1.623 & 0.681 & 1.808 \\
\hline 45 & 06885500 & 1 & 1.199 & 0.808 & 1.910 \\
\hline 46 & 06887000 & 2 & 1.843 & 0.721 & 0.847 \\
\hline 47 & 06888000 & 1 & 1.186 & 0.673 & 1.429 \\
\hline 48 & 06888500 & 1 & 0.945 & 1.163 & 2.176 \\
\hline 49 & 06889140 & 1 & 1.535 & 0.760 & 1.242 \\
\hline
\end{tabular}


Table 1-4. Observed/Expected (0/E) ratio values for the 10th percentile flow metrics assessed in this study.-Continued

[Diminished values are shown in bold. Inflated values are shown in italics. USGS, U.S. Geological Survey; -999, metric could not be computed]

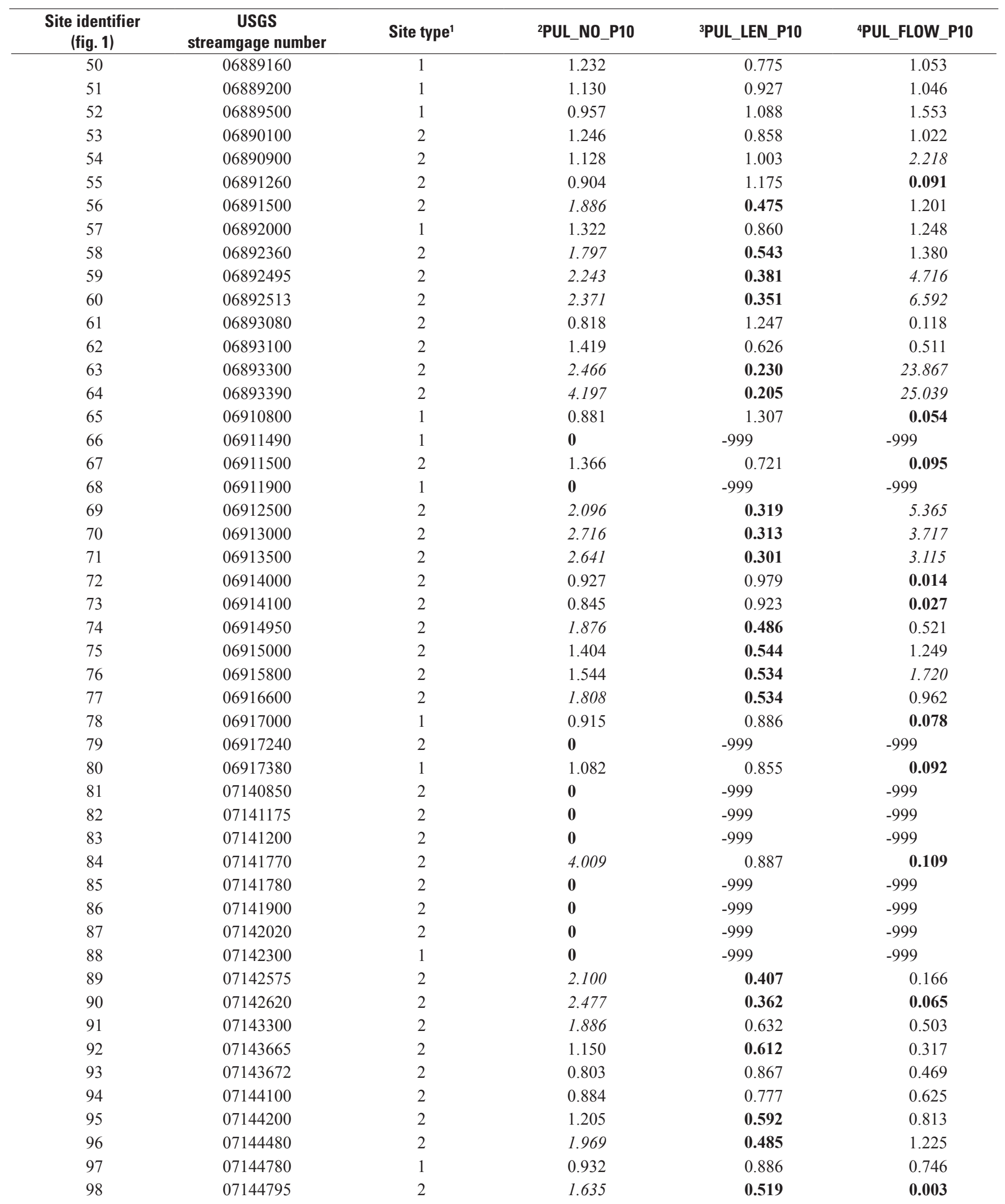


Table 1-4. Observed/Expected (0/E) ratio values for the 10th percentile flow metrics assessed in this study.-Continued

[Diminished values are shown in bold. Inflated values are shown in italics. USGS, U.S. Geological Survey; -999, metric could not be computed]

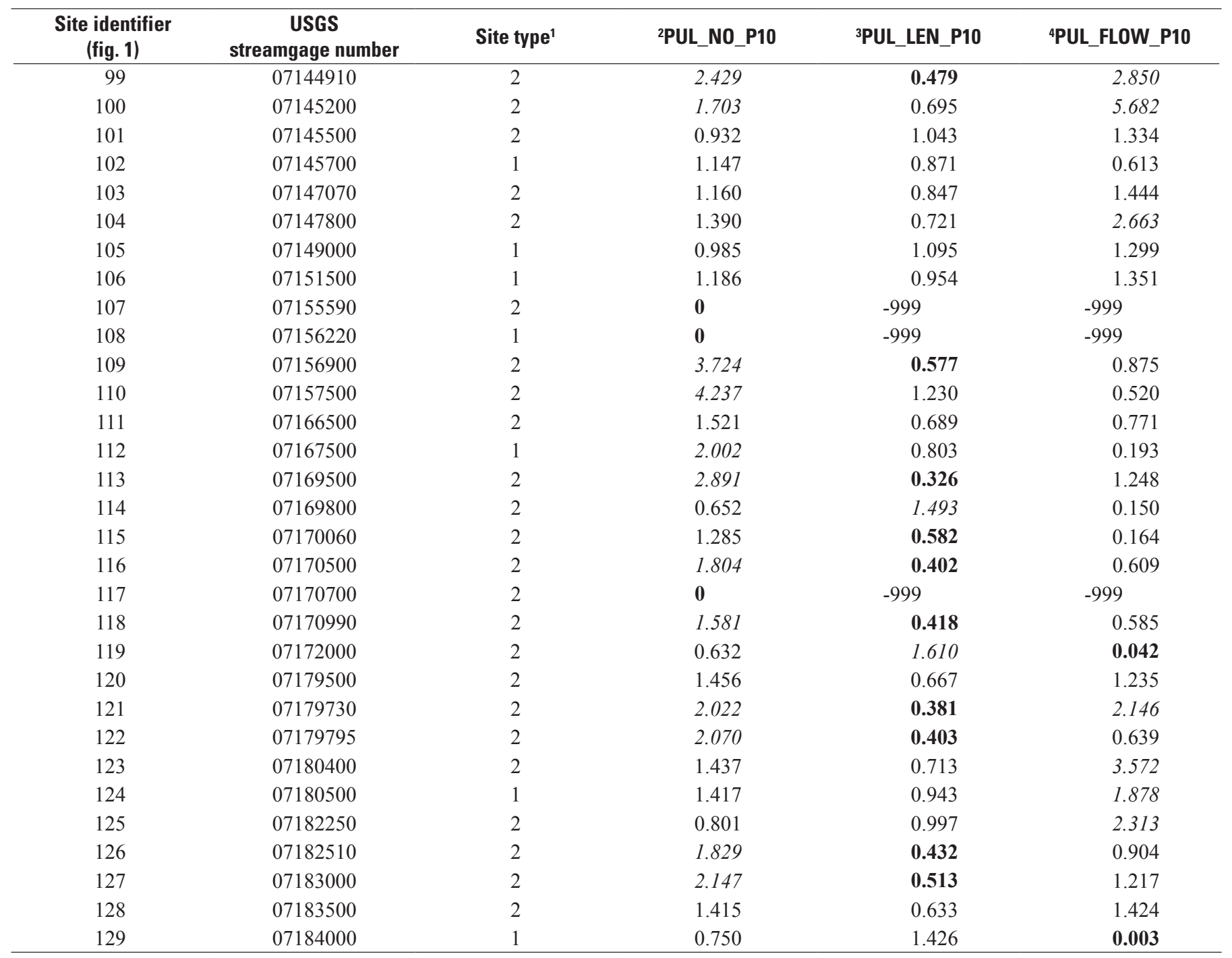

${ }^{1}$ Site type "1" indicates a reference (least-disturbed) site and site type "2" indicates a nonreference site (Falcone and others, 2010).

${ }^{2}$ Average annual number of flow pulses less than the 10th percentile. Tenth percentile error bound is 0.000 . Ninetieth percentile error bound is 1.550 .

${ }^{3}$ Average duration of flow pulses less than the 10th percentile. Tenth percentile error bound is 0.620 . Ninetieth percentile error bound is 1.440 .

${ }^{4}$ Average magnitude of flow pulses less than the 10th percentile, normalized by drainage area. Tenth percentile error bound is 0.110 . Ninetieth percentile error bound is 1.710 . 
Table 1-5. Observed/Expected (0/E) ratio values for the 25th percentile flow metrics assessed in this study.

[Diminished values are shown in bold. Inflated values are shown in italics. USGS, U.S. Geological Survey; -999, metric could not be computed]

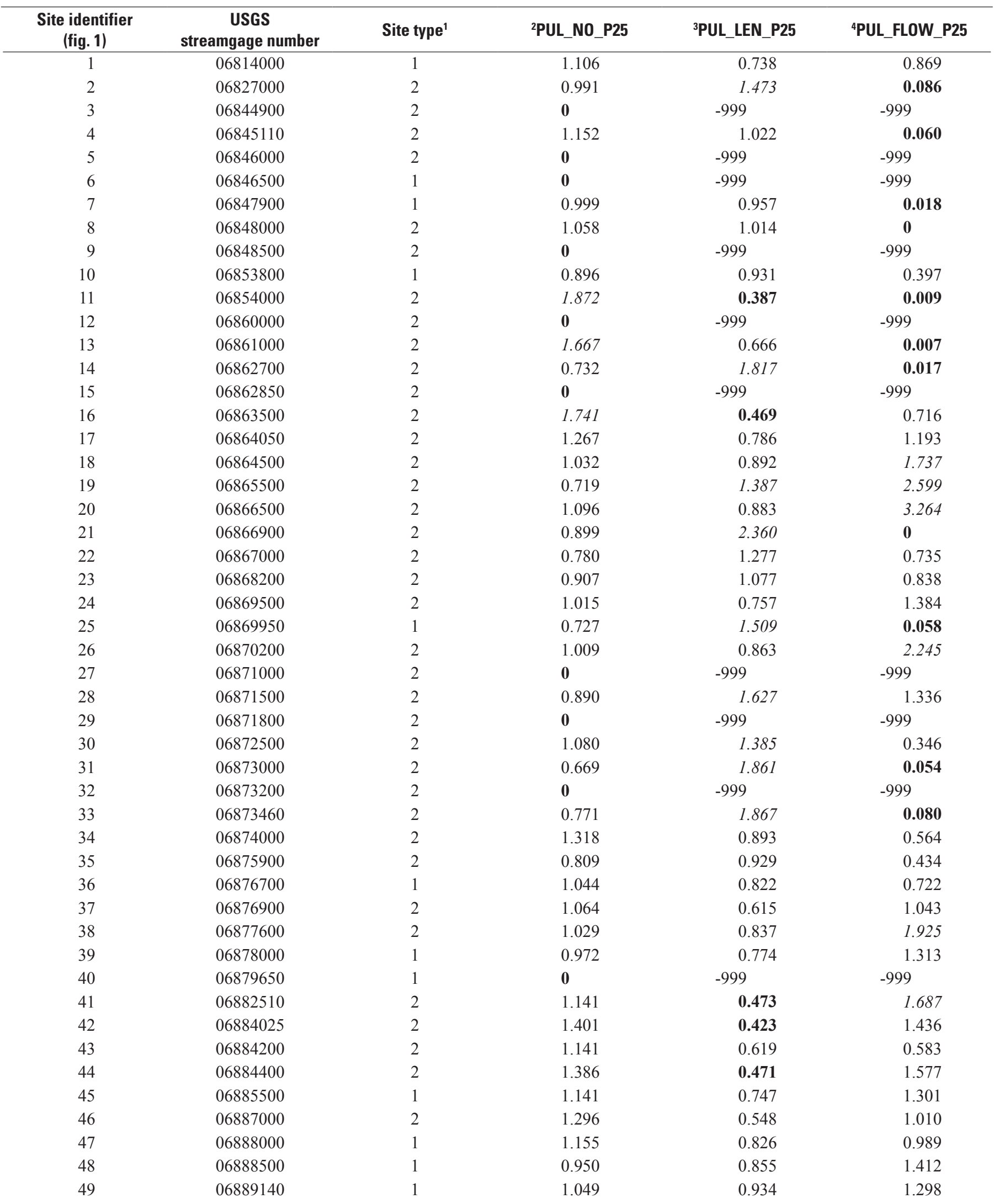


Table 1-5. Observed/Expected (O/E) ratio values for the 25th percentile flow metrics assessed in this study.-Continued

[Diminished values are shown in bold. Inflated values are shown in italics. USGS, U.S. Geological Survey; -999, metric could not be computed]

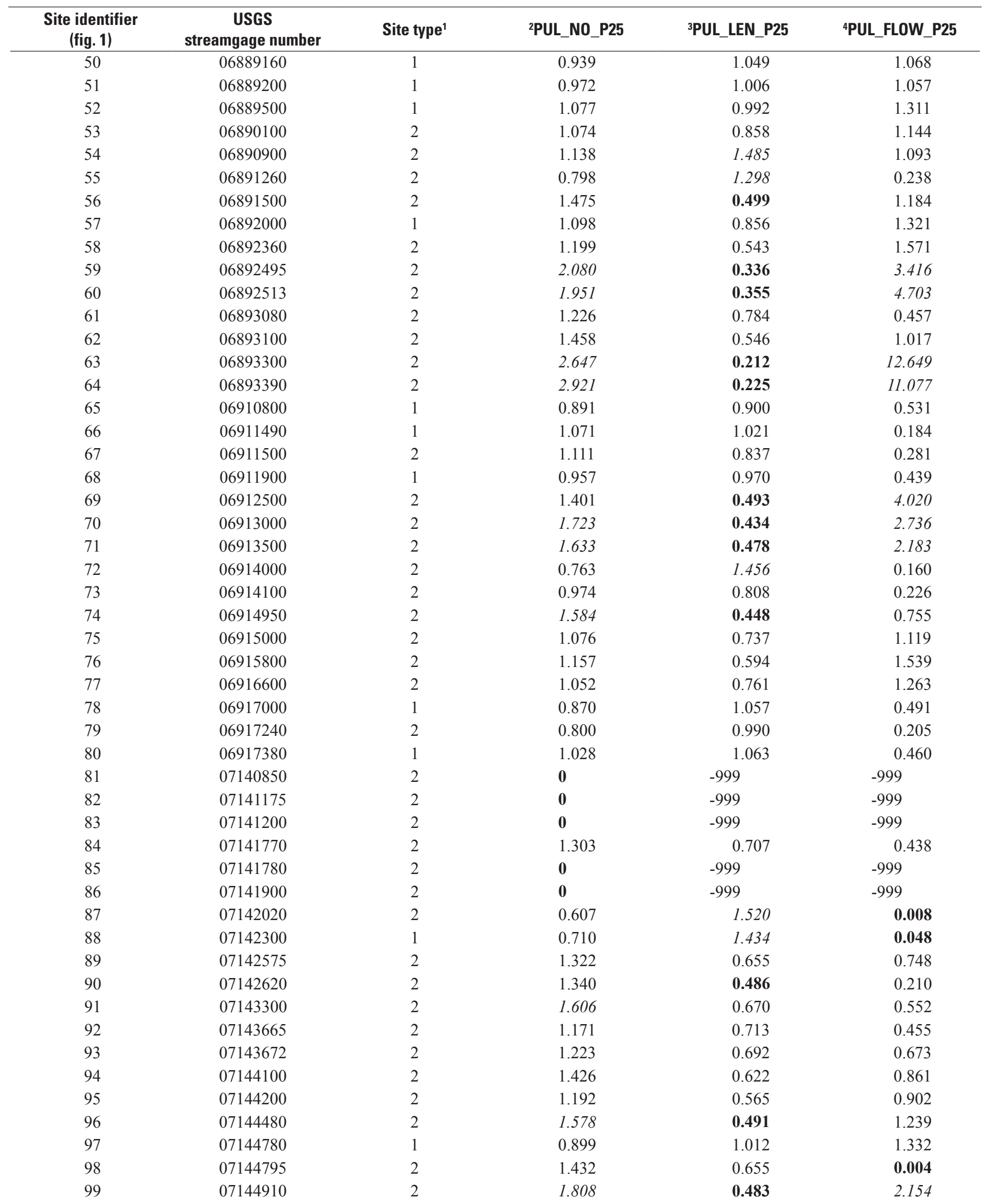


Table 1-5. Observed/Expected (O/E) ratio values for the 25th percentile flow metrics assessed in this study.-Continued

[Diminished values are shown in bold. Inflated values are shown in italics. USGS, U.S. Geological Survey; -999, metric could not be computed]

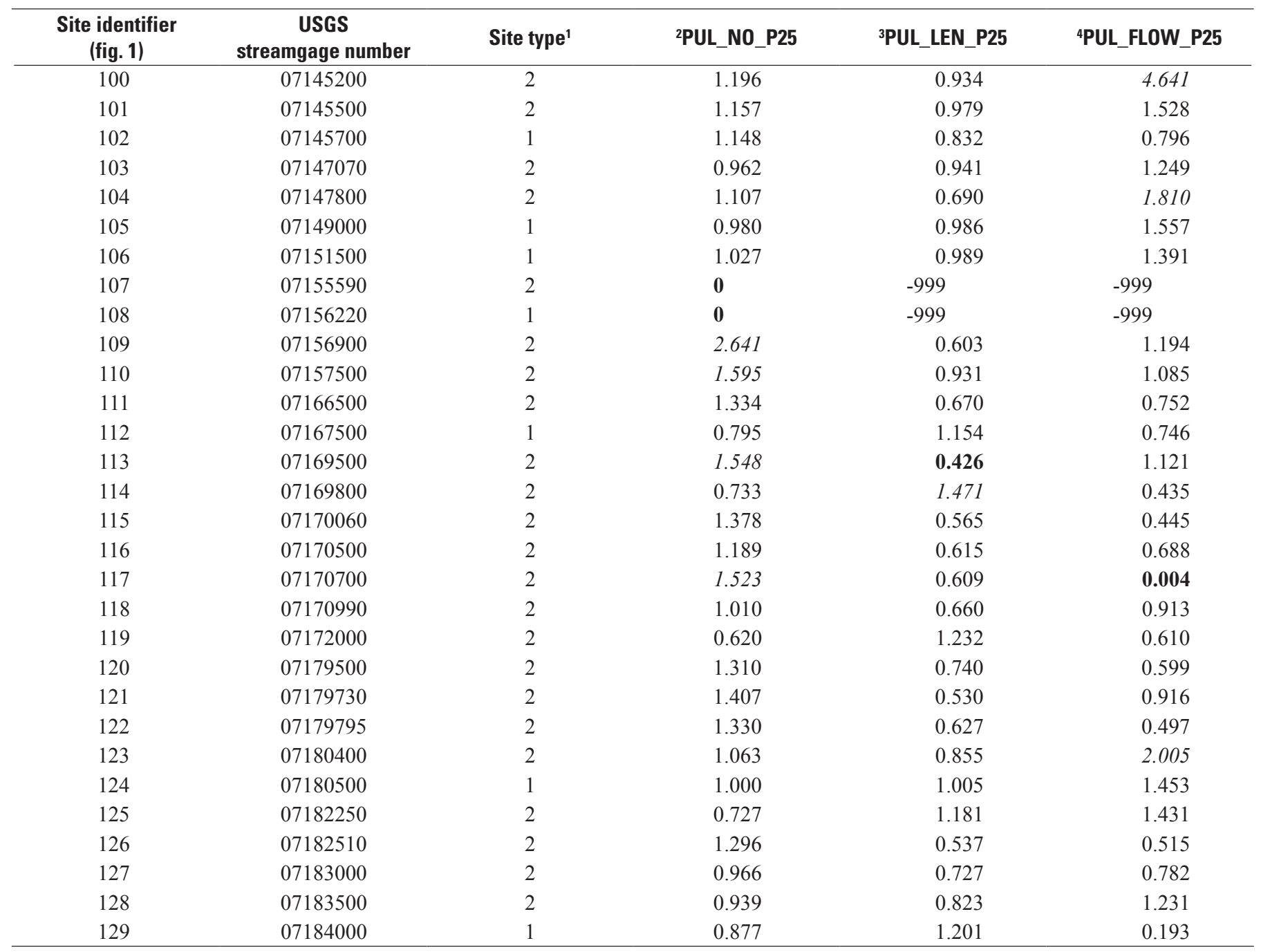

${ }^{1}$ Site type "1" indicates a reference (least-disturbed) site and site type " 2 " indicates a nonreference site (Falcone and others, 2010).

${ }^{2}$ Average annual number of flow pulses less than the 25 th percentile. Tenth percentile error bound is 0.540 . Ninetieth percentile error bound is 1.520 .

${ }^{3}$ Average duration of flow pulses less than the 25 th percentile. Tenth percentile error bound is 0.500 . Ninetieth percentile error bound is 1.280 .

${ }^{4}$ Average magnitude of flow pulses less than the 25 th percentile, normalized by drainage area. Tenth percentile error bound is 0.150 . Ninetieth percentile error bound is 1.590 . 
Table 1-6. Observed/Expected (0/E) ratio values for the 75th percentile flow metrics assessed in this study.

[Diminished values are shown in bold. Inflated values are shown in italics. USGS, U.S. Geological Survey]

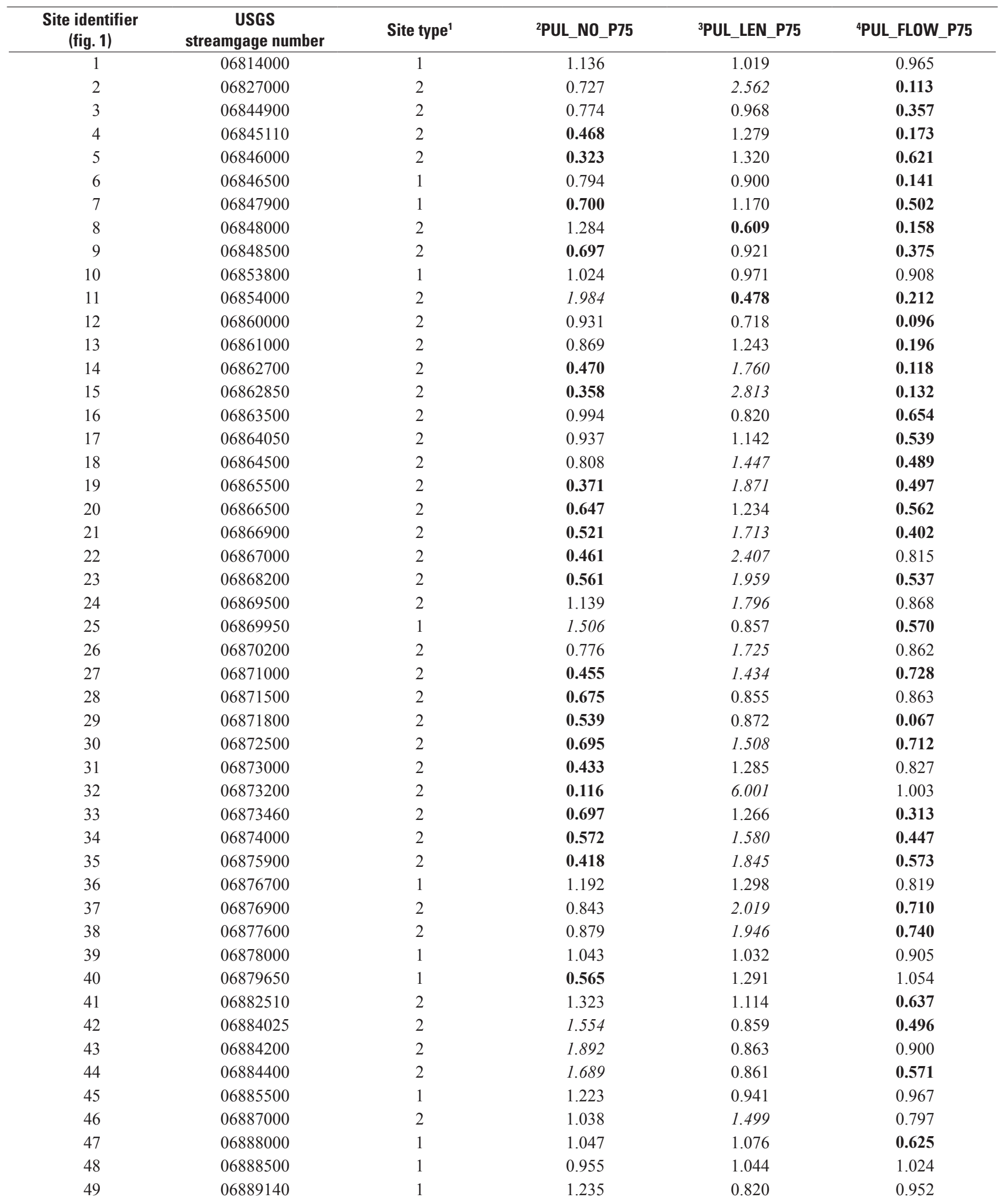


Table 1-6. Observed/Expected (O/E) ratio values for the 75th percentile flow metrics assessed in this study.—Continued

[Diminished values are shown in bold. Inflated values are shown in italics. USGS, U.S. Geological Survey]

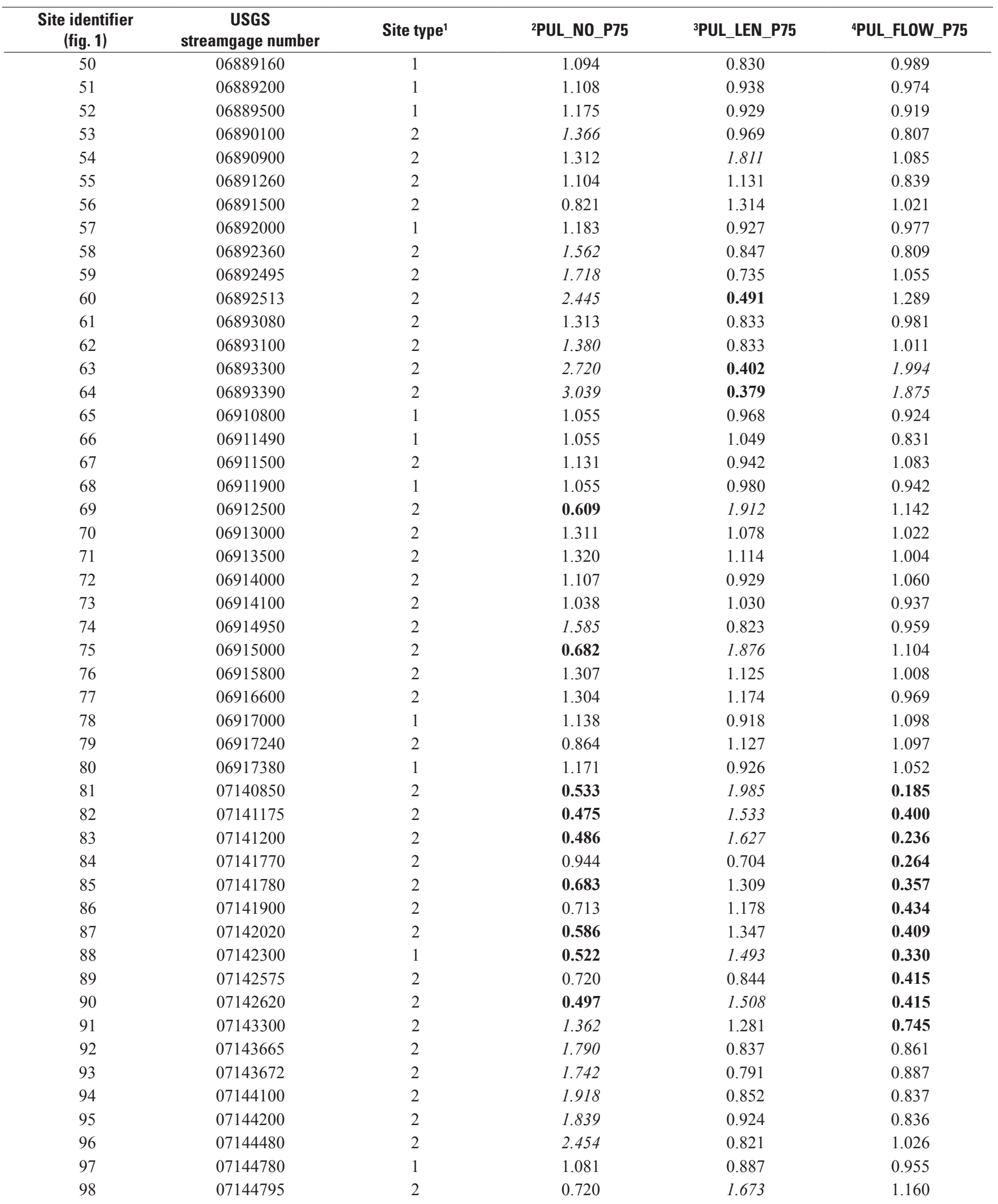


Table 1-6. Observed/Expected (0/E) ratio values for the 75th percentile flow metrics assessed in this study.-Continued

[Diminished values are shown in bold. Inflated values are shown in italics. USGS, U.S. Geological Survey]

\begin{tabular}{|c|c|c|c|c|c|}
\hline $\begin{array}{l}\text { Site identifier } \\
\text { (fig. 1) }\end{array}$ & $\begin{array}{c}\text { USGS } \\
\text { streamgage number }\end{array}$ & Site type ${ }^{1}$ & 2PUL_NO_P75 & 3PUL_LEN_P75 & ${ }^{4}$ PUL_FLOW_P75 \\
\hline 99 & 07144910 & 2 & 2.929 & 0.357 & 0.584 \\
\hline 100 & 07145200 & 2 & 1.871 & 0.611 & 1.283 \\
\hline 101 & 07145500 & 2 & 1.272 & 0.858 & 1.047 \\
\hline 102 & 07145700 & 1 & 1.331 & 0.743 & 1.154 \\
\hline 103 & 07147070 & 2 & 1.396 & 0.780 & 0.918 \\
\hline 106 & 07151500 & 1 & 1.205 & 0.926 & 1.084 \\
\hline 107 & 07155590 & 2 & 0.891 & 1.910 & 0.132 \\
\hline 108 & 07156220 & 1 & 0.461 & 0.269 & 1.304 \\
\hline 109 & 07156900 & 2 & 1.115 & 0.647 & 0.132 \\
\hline 110 & 07157500 & 2 & 0.705 & 0.998 & 0.163 \\
\hline 114 & 07169800 & 2 & 0.975 & 1.202 & 0.976 \\
\hline 115 & 07170060 & 2 & 0.932 & 1.123 & 1.133 \\
\hline 116 & 07170500 & 2 & 1.420 & 1.316 & 1.110 \\
\hline 117 & 07170700 & 2 & 0.603 & 1.752 & 1.061 \\
\hline 118 & 07170990 & 2 & 1.660 & 1.082 & 1.240 \\
\hline 119 & 07172000 & 2 & 0.818 & 1.136 & 1.189 \\
\hline 120 & 07179500 & 2 & 1.143 & 0.979 & 1.023 \\
\hline 121 & 07179730 & 2 & 1.388 & 0.972 & 0.816 \\
\hline 122 & 07179795 & 2 & 0.824 & 1.533 & 0.942 \\
\hline 123 & 07180400 & 2 & 1.564 & 0.987 & 0.778 \\
\hline
\end{tabular}

${ }^{1}$ Site type " 1 " indicates a reference (least-disturbed) site and site type " 2 " indicates a nonreference site (Falcone and others, 2010).

${ }^{2}$ Average annual number of flow pulses greater than the 75 th percentile. Tenth percentile error bound is 0.710 . Ninetieth percentile error bound is 1.360 .

${ }^{3}$ Average duration of flow pulses greater than the 75 th percentile. Tenth percentile error bound is 0.640 . Ninetieth percentile error bound is 1.350 .

${ }^{4}$ Average magnitude of flow pulses greater than the 75 th percentile, normalized by drainage area. Tenth percentile error bound is 0.750 . Ninetieth percentile error bound is 1.560 . 
Table 1-7. Observed/Expected (0/E) ratio values for the 90th percentile flow metrics assessed in this study.

[Diminished values are shown in bold. Inflated values are shown in italics. USGS, U.S. Geological Survey]

\begin{tabular}{|c|c|c|c|c|c|}
\hline $\begin{array}{l}\text { Site identifier } \\
\text { (fig. 1) }\end{array}$ & $\begin{array}{c}\text { USGS } \\
\text { streamgage number }\end{array}$ & Site type ${ }^{1}$ & 2PUL_NO_P90 & ${ }^{3}$ PUL_LEN_P90 & 4PUL_FLOW_P90 \\
\hline 1 & 06814000 & 1 & 0.979 & 0.481 & 1.038 \\
\hline 2 & 06827000 & 2 & 0.229 & 1.707 & 0.105 \\
\hline 4 & 06845110 & 2 & 0.481 & 0.736 & 0.138 \\
\hline 5 & 06846000 & 2 & 0.388 & 0.897 & 0.442 \\
\hline 8 & 06848000 & 2 & 1.020 & 0.504 & 0.178 \\
\hline 9 & 06848500 & 2 & 0.815 & 0.389 & 0.285 \\
\hline 10 & 06853800 & 1 & 0.733 & 0.507 & 0.812 \\
\hline 11 & 06854000 & 2 & 0.178 & 1.599 & 0.951 \\
\hline 12 & 06860000 & 2 & 0.882 & 0.478 & 0.097 \\
\hline 16 & 06863500 & 2 & 0.527 & 0.438 & 0.574 \\
\hline 17 & 06864050 & 2 & 0.803 & 0.497 & 0.514 \\
\hline 18 & 06864500 & 2 & 0.845 & 0.557 & 0.510 \\
\hline 19 & 06865500 & 2 & 0.291 & 1.586 & 0.570 \\
\hline 20 & 06866500 & 2 & 0.593 & 0.711 & 0.578 \\
\hline 21 & 06866900 & 2 & 0.583 & 0.944 & 0.469 \\
\hline 22 & 06867000 & 2 & 0.490 & 0.931 & 0.722 \\
\hline 23 & 06868200 & 2 & 0.644 & 1.224 & 0.678 \\
\hline 24 & 06869500 & 2 & 0.683 & 0.743 & 0.825 \\
\hline 25 & 06869950 & 1 & 0.686 & 0.311 & 0.567 \\
\hline 33 & 06873460 & 2 & 0.399 & 1.003 & 0.441 \\
\hline 34 & 06874000 & 2 & 0.851 & 0.956 & 0.456 \\
\hline 35 & 06875900 & 2 & 0.339 & 1.218 & 0.513 \\
\hline 36 & 06876700 & 1 & 0.624 & 0.610 & 0.860 \\
\hline 37 & 06876900 & 2 & 0.584 & 0.860 & 0.668 \\
\hline 38 & 06877600 & 2 & 0.581 & 0.996 & 0.586 \\
\hline 39 & 06878000 & 1 & 1.049 & 0.359 & 0.832 \\
\hline 40 & 06879650 & 1 & 0.458 & 0.642 & 0.977 \\
\hline 41 & 06882510 & 2 & 1.101 & 0.566 & 0.584 \\
\hline 42 & 06884025 & 2 & 1.250 & 0.446 & 0.481 \\
\hline 43 & 06884200 & 2 & 0.820 & 0.388 & 0.938 \\
\hline 44 & 06884400 & 2 & 1.169 & 0.454 & 0.557 \\
\hline 45 & 06885500 & 1 & 1.137 & 0.457 & 0.999 \\
\hline 46 & 06887000 & 2 & 0.467 & 1.264 & 0.660 \\
\hline 47 & 06888000 & 1 & 1.133 & 0.492 & 0.638 \\
\hline 48 & 06888500 & 1 & 0.943 & 0.603 & 0.981 \\
\hline 49 & 06889140 & 1 & 1.244 & 0.473 & 1.127 \\
\hline
\end{tabular}


Table 1-7. Observed/Expected (O/E) ratio values for the 90th percentile flow metrics assessed in this study.-Continued [Diminished values are shown in bold. Inflated values are shown in italics. USGS, U.S. Geological Survey]

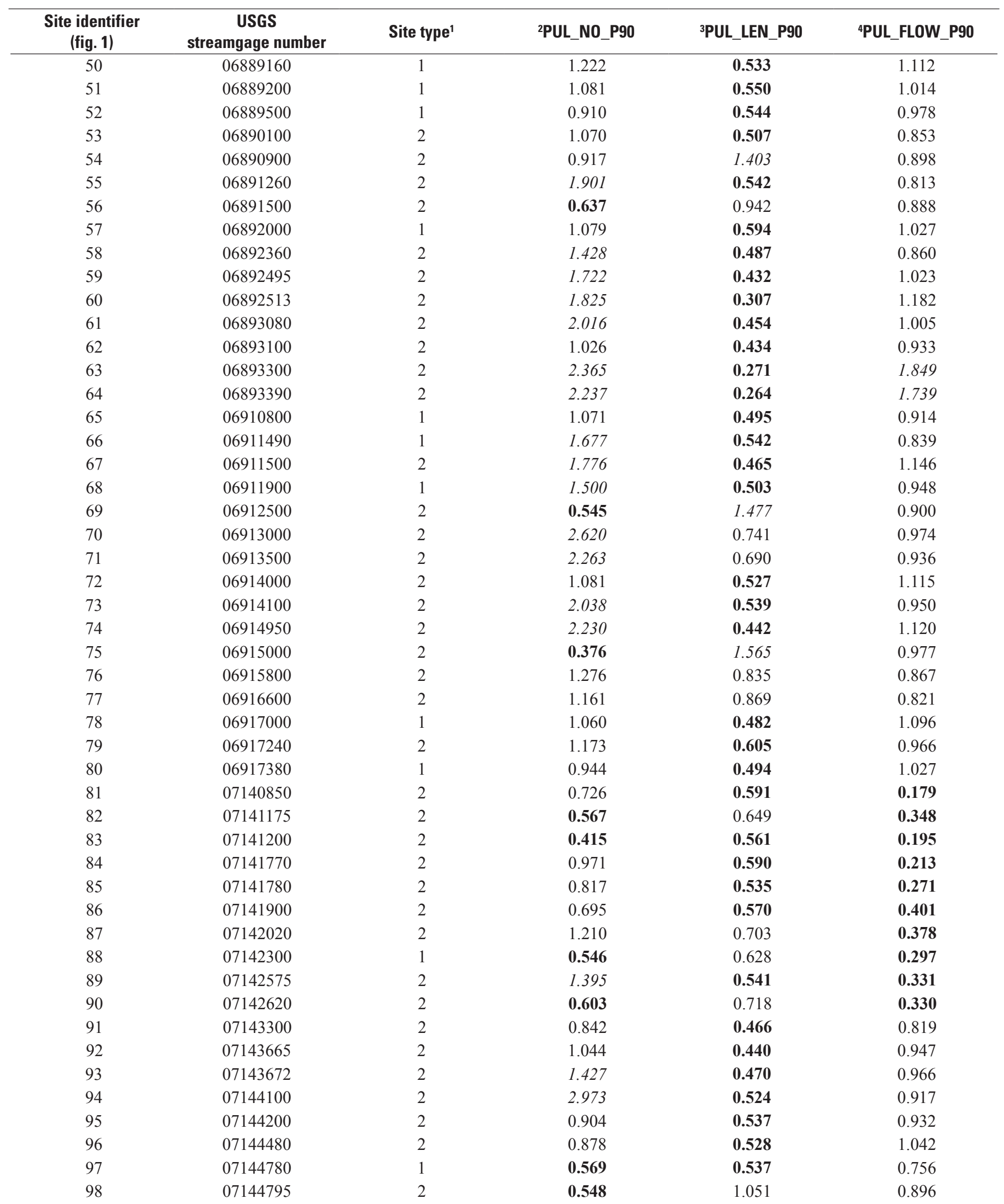




\section{Streamflow Alteration at Selected Sites in Kansas}

Table 1-7. Observed/Expected (0/E) ratio values for the 90th percentile flow metrics assessed in this study.-Continued

[Diminished values are shown in bold. Inflated values are shown in italics. USGS, U.S. Geological Survey]

\begin{tabular}{|c|c|c|c|c|c|}
\hline $\begin{array}{l}\text { Site identifier } \\
\text { (fig. 1) }\end{array}$ & $\begin{array}{c}\text { USGS } \\
\text { streamgage number }\end{array}$ & Site type ${ }^{1}$ & 2PUL_NO_P90 & 3PUL_LEN_P90 & ${ }^{4}$ PUL_FLOW_P9C \\
\hline 99 & 07144910 & 2 & 0.774 & 0.324 & 0.417 \\
\hline 100 & 07145200 & 2 & 0.910 & 0.395 & 0.973 \\
\hline 101 & 07145500 & 2 & 0.550 & 0.591 & 0.941 \\
\hline 102 & 07145700 & 1 & 0.881 & 0.418 & 1.214 \\
\hline 103 & 07147070 & 2 & 1.055 & 0.382 & 0.912 \\
\hline 104 & 07147800 & 2 & 2.281 & 0.437 & 0.974 \\
\hline 105 & 07149000 & 1 & 1.232 & 0.441 & 0.833 \\
\hline 106 & 07151500 & 1 & 1.340 & 0.443 & 0.975 \\
\hline 107 & 07155590 & 2 & 1.015 & 1.587 & 0.071 \\
\hline 108 & 07156220 & 1 & 0.457 & 0.348 & 0.701 \\
\hline 109 & 07156900 & 2 & 1.248 & 0.458 & 0.083 \\
\hline 110 & 07157500 & 2 & 0.356 & 0.885 & 0.094 \\
\hline 111 & 07166500 & 2 & 1.456 & 0.751 & 0.971 \\
\hline 112 & 07167500 & 1 & 1.215 & 0.499 & 1.080 \\
\hline 113 & 07169500 & 2 & 1.323 & 0.622 & 1.168 \\
\hline 114 & 07169800 & 2 & 0.617 & 0.658 & 0.930 \\
\hline 115 & 07170060 & 2 & 0.661 & 1.265 & 1.080 \\
\hline 116 & 07170500 & 2 & 1.549 & 0.863 & 0.961 \\
\hline 117 & 07170700 & 2 & 0.820 & 1.002 & 0.981 \\
\hline 118 & 07170990 & 2 & 1.298 & 0.643 & 0.969 \\
\hline 119 & 07172000 & 2 & 0.866 & 0.602 & 1.104 \\
\hline 120 & 07179500 & 2 & 0.406 & 0.855 & 0.850 \\
\hline 121 & 07179730 & 2 & 0.698 & 0.654 & 0.927 \\
\hline 122 & 07179795 & 2 & 0.371 & 1.128 & 1.030 \\
\hline 123 & 07180400 & 2 & 1.100 & 0.497 & 0.829 \\
\hline 124 & 07180500 & 1 & 0.983 & 0.394 & 1.062 \\
\hline 125 & 07182250 & 2 & 1.942 & 0.558 & 0.824 \\
\hline 126 & 07182510 & 2 & 0.734 & 0.944 & 0.887 \\
\hline 127 & 07183000 & 2 & 1.100 & 0.731 & 0.898 \\
\hline 128 & 07183500 & 2 & 1.159 & 0.698 & 0.837 \\
\hline 129 & 07184000 & 1 & 1.268 & 0.472 & 1.139 \\
\hline
\end{tabular}

${ }^{1}$ Site type "1" indicates a reference (least-disturbed) site and site type "2" indicates a nonreference site (Falcone and others, 2010).

${ }^{2}$ Average annual number of flow pulses greater than the 90th percentile. Tenth percentile error bound is 0.690 . Ninetieth percentile error bound is 1.340 .

${ }^{3}$ Average duration of flow pulses greater than the 90th percentile. Tenth percentile error bound is 0.610 . Ninetieth percentile error bound is 1.280 .

${ }^{4}$ Average magnitude of flow pulses greater than the 90th percentile, normalized by drainage area. Tenth percentile error bound is 0.730 . Ninetieth percentile error bound is 1.430 . 
Table 1-8. Observed/Expected (O/E) ratio values for five annual flow metrics assessed in this study.

[Diminished values are shown in bold. Inflated values are shown in italics. USGS, U.S. Geological Survey]

\begin{tabular}{|c|c|c|c|c|c|c|c|}
\hline $\begin{array}{l}\text { Site identifier } \\
\text { (fig. 1) }\end{array}$ & $\begin{array}{c}\text { USGS } \\
\text { streamgage number }\end{array}$ & Site type ${ }^{1}$ & PER_BSFL ${ }^{2}$ & ${ }^{3} \mathrm{P} 10$ & 4P50 & ${ }^{5} \mathrm{P} 90$ & CV_FLOW ${ }^{6}$ \\
\hline 1 & 06814000 & 1 & 1.091 & 1.055 & 1.066 & 0.567 & 1.062 \\
\hline 2 & 06827000 & 2 & 0.042 & 0.261 & 1.131 & 0.375 & 0.434 \\
\hline 3 & 06844900 & 2 & 0.237 & 0.043 & 0.046 & 0.024 & 1.064 \\
\hline 4 & 06845110 & 2 & 0.283 & 0.295 & 0.306 & 0.116 & 0.877 \\
\hline 5 & 06846000 & 2 & 0.093 & 0.013 & 0.138 & 0.072 & 1.023 \\
\hline 6 & 06846500 & 1 & 0.954 & $\mathbf{0}$ & 0.099 & 0.065 & 0.993 \\
\hline 7 & 06847900 & 1 & 0.753 & 0.388 & 0.357 & 0.243 & 0.938 \\
\hline 8 & 06848000 & 2 & 0.650 & 0.055 & 0.014 & 0.093 & 0.853 \\
\hline 9 & 06848500 & 2 & 1.078 & 0.189 & 0.146 & 0.075 & 0.957 \\
\hline 10 & 06853800 & 1 & 0.850 & 0.619 & 0.874 & 0.361 & 1.084 \\
\hline 11 & 06854000 & 2 & 0.998 & 0.007 & 0.253 & 0.518 & 1.966 \\
\hline 12 & 06860000 & 2 & 2.411 & 0.017 & 0.074 & 0.084 & 1.155 \\
\hline 13 & 06861000 & 2 & 1.718 & 0.169 & 0.215 & 0.132 & 0.969 \\
\hline 14 & 06862700 & 2 & 1.018 & 0.404 & 0.203 & 0.079 & 0.985 \\
\hline 15 & 06862850 & 2 & 1.309 & 0.351 & 0.179 & 0.085 & 1.081 \\
\hline 16 & 06863500 & 2 & 1.077 & 1.965 & 0.602 & 0.179 & 0.997 \\
\hline 17 & 06864050 & 2 & 1.327 & 3.590 & 0.531 & 0.478 & 0.742 \\
\hline 18 & 06864500 & 2 & 1.124 & 7.737 & 0.900 & 0.607 & 0.866 \\
\hline 19 & 06865500 & 2 & 0.528 & 7.086 & 1.301 & 0.683 & 0.901 \\
\hline 20 & 06866500 & 2 & 0.548 & 8.914 & 1.358 & 0.667 & 0.927 \\
\hline 21 & 06866900 & 2 & 0.559 & 0.521 & 0.240 & 0.166 & 1.300 \\
\hline 22 & 06867000 & 2 & 0.767 & 2.351 & 0.806 & 0.271 & 1.282 \\
\hline 23 & 06868200 & 2 & 0.444 & 0.776 & 0.729 & 0.372 & 1.568 \\
\hline 24 & 06869500 & 2 & 0.541 & 1.700 & 0.982 & 0.361 & 1.413 \\
\hline 25 & 06869950 & 1 & 0.050 & 0.373 & 0.325 & 0.190 & 1.261 \\
\hline 26 & 06870200 & 2 & 0.479 & 3.288 & 1.341 & 0.439 & 1.105 \\
\hline 27 & 06871000 & 2 & 0.506 & 1.047 & 0.552 & 0.228 & 0.854 \\
\hline 28 & 06871500 & 2 & 0.739 & 2.296 & 0.708 & 0.247 & 0.775 \\
\hline 29 & 06871800 & 2 & 0.224 & 0.001 & 0.052 & 0.115 & 1.874 \\
\hline 30 & 06872500 & 2 & 0.498 & 0.894 & 0.773 & 0.266 & 1.099 \\
\hline 31 & 06873000 & 2 & 0.714 & 1.320 & 0.628 & 0.293 & 1.002 \\
\hline 32 & 06873200 & 2 & 0.331 & 0.029 & 0.349 & 0.484 & 1.051 \\
\hline 33 & 06873460 & 2 & 0.737 & 0.511 & 0.388 & 0.213 & 1.654 \\
\hline 34 & 06874000 & 2 & 0.654 & 1.348 & 0.537 & 0.215 & 1.852 \\
\hline 35 & 06875900 & 2 & 0.271 & 0.886 & 0.867 & 0.309 & 1.489 \\
\hline 36 & 06876700 & 1 & 1.061 & 0.928 & 0.645 & 0.537 & 1.169 \\
\hline 37 & 06876900 & 2 & 0.381 & 1.672 & 0.875 & 0.365 & 1.315 \\
\hline 38 & 06877600 & 2 & 0.445 & 2.821 & 1.233 & 0.407 & 1.165 \\
\hline 39 & 06878000 & 1 & 0.752 & 1.307 & 0.963 & 0.498 & 0.981 \\
\hline 40 & 06879650 & 1 & 13.167 & 0.217 & 0.870 & 0.570 & 1.110 \\
\hline 41 & 06882510 & 2 & 0.595 & 1.226 & 0.873 & 0.569 & 0.917 \\
\hline 42 & 06884025 & 2 & 0.757 & 1.108 & 0.939 & 0.457 & 0.870 \\
\hline 43 & 06884200 & 2 & 1.292 & 0.682 & 0.672 & 0.608 & 1.120 \\
\hline 44 & 06884400 & 2 & 0.729 & 1.270 & 0.941 & 0.550 & 0.818 \\
\hline 45 & 06885500 & 1 & 1.014 & 1.249 & 0.965 & 0.608 & 1.063 \\
\hline 46 & 06887000 & 2 & 0.533 & 0.782 & 1.244 & 0.788 & 0.995 \\
\hline 47 & 06888000 & 1 & 0.017 & 0.698 & 0.790 & 0.426 & 0.941 \\
\hline 48 & 06888500 & 1 & 0.789 & 1.285 & 1.159 & 0.593 & 0.903 \\
\hline 49 & 06889140 & 1 & 0.709 & 1.437 & 1.145 & 0.555 & 1.133 \\
\hline 50 & 06889160 & 1 & 0.942 & 1.222 & 1.085 & 0.565 & 1.033 \\
\hline
\end{tabular}


Table 1-8. Observed/Expected (0/E) ratio values for five annual flow metrics assessed in this study.-Continued

[Diminished values are shown in bold. Inflated values are shown in italics. USGS, U.S. Geological Survey]

\begin{tabular}{|c|c|c|c|c|c|c|c|}
\hline $\begin{array}{l}\text { Site identifier } \\
\text { (fig. 1) }\end{array}$ & $\begin{array}{c}\text { USGS } \\
\text { streamgage number }\end{array}$ & Site type ${ }^{1}$ & PER_BSFL ${ }^{2}$ & ${ }^{3} \mathrm{P} 10$ & ${ }^{4} \mathrm{P} 50$ & ${ }^{5} \mathrm{P} 90$ & CV_FLOW \\
\hline 51 & 06889200 & 1 & 1.416 & 1.084 & 1.069 & 0.543 & 0.999 \\
\hline 52 & 06889500 & 1 & 1.076 & 1.165 & 1.035 & 0.532 & 0.933 \\
\hline 53 & 06890100 & 2 & 1.153 & 1.274 & 1.084 & 0.563 & 0.992 \\
\hline 54 & 06890900 & 2 & 0.669 & 1.255 & 1.323 & 0.976 & 0.896 \\
\hline 55 & 06891260 & 2 & 0.067 & 0.653 & 0.769 & 0.468 & 1.014 \\
\hline 56 & 06891500 & 2 & 0.491 & 1.013 & 1.076 & 0.848 & 1.019 \\
\hline 57 & 06892000 & 1 & 1.226 & 1.256 & 1.080 & 0.642 & 0.917 \\
\hline 58 & 06892360 & 2 & 0.169 & 1.797 & 1.160 & 0.514 & 0.828 \\
\hline 59 & 06892495 & 2 & 0.228 & 2.946 & 1.855 & 0.571 & 0.757 \\
\hline 60 & 06892513 & 2 & 0.476 & 4.185 & 1.905 & 0.720 & 0.602 \\
\hline 61 & 06893080 & 2 & 6.483 & 0.513 & 0.748 & 0.476 & 0.823 \\
\hline 62 & 06893100 & 2 & 1.553 & 1.085 & 0.982 & 0.532 & 0.729 \\
\hline 63 & 06893300 & 2 & 2.321 & 13.038 & 3.120 & 0.956 & 0.498 \\
\hline 64 & 06893390 & 2 & 0.879 & 11.417 & 2.887 & 1.009 & 0.364 \\
\hline 65 & 06910800 & 1 & 1.839 & 0.797 & 0.851 & 0.514 & 0.981 \\
\hline 66 & 06911490 & 1 & 0.703 & 0.532 & 0.477 & 0.380 & 1.129 \\
\hline 67 & 06911500 & 2 & 1.253 & 0.444 & 0.693 & 0.540 & 0.812 \\
\hline 68 & 06911900 & 1 & 1.894 & 0.626 & 0.763 & 0.455 & 0.974 \\
\hline 69 & 06912500 & 2 & 0.573 & 2.747 & 0.958 & 0.974 & 0.952 \\
\hline 70 & 06913000 & 2 & 0.633 & 2.620 & 1.525 & 0.966 & 0.958 \\
\hline 71 & 06913500 & 2 & 0.641 & 2.300 & 1.501 & 0.885 & 0.972 \\
\hline 72 & 06914000 & 2 & 0.294 & 0.296 & 0.677 & 0.711 & 0.946 \\
\hline 73 & 06914100 & 2 & 0.175 & 0.529 & 0.570 & 0.622 & 1.069 \\
\hline 74 & 06914950 & 2 & 0.068 & 0.806 & 0.542 & 0.359 & 0.813 \\
\hline 75 & 06915000 & 2 & 0.453 & 1.620 & 0.912 & 0.716 & 1.057 \\
\hline 76 & 06915800 & 2 & 0.565 & 2.115 & 1.780 & 0.814 & 0.989 \\
\hline 77 & 06916600 & 2 & 0.572 & 1.710 & 1.566 & 0.779 & 0.899 \\
\hline 78 & 06917000 & 1 & 1.148 & 0.865 & 1.016 & 0.588 & 0.864 \\
\hline 79 & 06917240 & 2 & 0.377 & 0.516 & 0.892 & 0.599 & 0.797 \\
\hline 80 & 06917380 & 1 & 1.236 & 0.672 & 0.894 & 0.509 & 0.919 \\
\hline 81 & 07140850 & 2 & 1.527 & 0.061 & 0.124 & 0.066 & 1.335 \\
\hline 82 & 07141175 & 2 & 1.082 & 0.848 & 0.331 & 0.148 & 1.378 \\
\hline 83 & 07141200 & 2 & 3.210 & 0.241 & 0.104 & 0.110 & 1.051 \\
\hline 84 & 07141770 & 2 & 0.779 & 1.574 & 0.555 & 0.136 & 0.709 \\
\hline 85 & 07141780 & 2 & 1.198 & 1.419 & 0.398 & 0.132 & 1.171 \\
\hline 86 & 07141900 & 2 & 1.096 & 1.698 & 0.517 & 0.176 & 1.063 \\
\hline 87 & 07142020 & 2 & 0.536 & 0.711 & 0.528 & 0.276 & 0.734 \\
\hline 88 & 07142300 & 1 & 0.873 & 0.356 & 0.441 & 0.161 & 0.827 \\
\hline 89 & 07142575 & 2 & 1.054 & 0.699 & 0.668 & 0.222 & 0.888 \\
\hline 90 & 07142620 & 2 & 0.692 & 0.230 & 0.296 & 0.229 & 0.761 \\
\hline 91 & 07143300 & 2 & 0.898 & 0.627 & 0.319 & 0.348 & 1.197 \\
\hline 92 & 07143665 & 2 & 3.355 & 0.419 & 0.307 & 0.642 & 1.054 \\
\hline 93 & 07143672 & 2 & 1.862 & 0.557 & 0.356 & 0.574 & 0.722 \\
\hline 94 & 07144100 & 2 & 1.547 & 0.708 & 0.443 & 0.534 & 0.716 \\
\hline 95 & 07144200 & 2 & 1.568 & 0.850 & 0.503 & 0.672 & 0.974 \\
\hline 96 & 07144480 & 2 & 0.236 & 1.340 & 0.529 & 0.497 & 0.713 \\
\hline 97 & 07144780 & 1 & 0.952 & 1.209 & 1.096 & 0.517 & 0.701 \\
\hline
\end{tabular}


Table 1-8. Observed/Expected (O/E) ratio values for five annual flow metrics assessed in this study.—Continued

[Diminished values are shown in bold. Inflated values are shown in italics. USGS, U.S. Geological Survey]

\begin{tabular}{|c|c|c|c|c|c|c|c|}
\hline $\begin{array}{l}\text { Site identifier } \\
\text { (fig. 1) }\end{array}$ & $\begin{array}{c}\text { USGS } \\
\text { streamgage number }\end{array}$ & Site type ${ }^{1}$ & PER_BSFL ${ }^{2}$ & ${ }^{3} \mathrm{P} 10$ & ${ }^{4} \mathrm{P} 50$ & ${ }^{5} \mathrm{P} 90$ & CV_FLOW \\
\hline 98 & 07144795 & 2 & 1.815 & 0.007 & 0.126 & 0.781 & 0.876 \\
\hline 99 & 07144910 & 2 & 0.830 & 2.143 & 0.914 & 0.332 & 0.653 \\
\hline 100 & 07145200 & 2 & 0.655 & 4.092 & 2.689 & 0.892 & 0.364 \\
\hline 101 & 07145500 & 2 & 0.891 & 1.458 & 1.503 & 0.848 & 0.579 \\
\hline 102 & 07145700 & 1 & 2.603 & 0.822 & 0.820 & 0.546 & 0.904 \\
\hline 103 & 07147070 & 2 & 0.971 & 1.172 & 0.768 & 0.515 & 0.972 \\
\hline 104 & 07147800 & 2 & 0.748 & 1.515 & 1.177 & 0.818 & 0.905 \\
\hline 105 & 07149000 & 1 & 0.853 & 1.464 & 1.269 & 0.617 & 0.826 \\
\hline 106 & 07151500 & 1 & 0.950 & 1.387 & 1.256 & 0.627 & 0.783 \\
\hline 107 & 07155590 & 2 & 0.164 & o & 0.001 & 0.008 & 1.610 \\
\hline 108 & 07156220 & 1 & 0.102 & 0 & 0 & 0 & 1.039 \\
\hline 109 & 07156900 & 2 & 0.146 & 3.528 & 4.241 & 0.404 & 0.184 \\
\hline 110 & 07157500 & 2 & 0.510 & 7.200 & 0.770 & 0.139 & 0.413 \\
\hline 111 & 07166500 & 2 & 0.778 & 0.930 & 1.535 & 0.993 & 0.836 \\
\hline 112 & 07167500 & 1 & 1.354 & 0.943 & 0.975 & 0.585 & 0.922 \\
\hline 113 & 07169500 & 2 & 0.687 & 1.115 & 1.610 & 1.154 & 0.886 \\
\hline 114 & 07169800 & 2 & 1.091 & 0.729 & 0.992 & 0.640 & 0.898 \\
\hline 115 & 07170060 & 2 & 0.642 & 0.457 & 0.652 & 1.207 & 0.870 \\
\hline 116 & 07170500 & 2 & 0.558 & 1.296 & 1.763 & 1.060 & 0.849 \\
\hline 117 & 07170700 & 2 & 1.960 & 0.131 & 0.522 & 0.589 & 1.177 \\
\hline 118 & 07170990 & 2 & 0.596 & 1.775 & 2.190 & 1.049 & 0.919 \\
\hline 119 & 07172000 & 2 & 1.053 & 0.693 & 1.377 & 0.980 & 0.926 \\
\hline 120 & 07179500 & 2 & 1.014 & 0.437 & 0.445 & 0.760 & 1.128 \\
\hline 121 & 07179730 & 2 & 0.820 & 0.918 & 0.851 & 0.803 & 1.081 \\
\hline 122 & 07179795 & 2 & 0.963 & 0.362 & 0.481 & 0.514 & 1.403 \\
\hline 123 & 07180400 & 2 & 0.570 & 1.887 & 1.123 & 0.598 & 1.020 \\
\hline 124 & 07180500 & 1 & 1.058 & 1.400 & 1.240 & 0.606 & 0.898 \\
\hline 125 & 07182250 & 2 & 0.660 & 1.628 & 1.332 & 0.700 & 0.843 \\
\hline 126 & 07182510 & 2 & 0.597 & 0.679 & 1.348 & 1.025 & 0.903 \\
\hline 127 & 07183000 & 2 & 0.552 & 1.034 & 1.590 & 0.911 & 0.890 \\
\hline 128 & 07183500 & 2 & 0.498 & 1.598 & 1.885 & 0.813 & 0.837 \\
\hline 129 & 07184000 & 1 & 2.140 & 0.329 & 0.626 & 0.581 & 1.004 \\
\hline
\end{tabular}

${ }^{1}$ Site type " 1 " indicates a reference (least-disturbed) site and site type " 2 " indicates a nonreference site (Falcone and others, 2010).

${ }^{2}$ Percentage of flow that is baseflow. Tenth percentile error bound is 0.180 . Ninetieth percentile error bound is 1.810 .

${ }^{3}$ Tenth percentile flow normalized by drainage area. Tenth percentile error bound is 0.200 . Ninetieth percentile error bound is 1.900 .

${ }^{4}$ Median annual flow normalized by drainage area. Tenth percentile error bound is 0.370 . Ninetieth percentile error bound is 1.770 .

${ }^{5}$ Ninetieth percentile flow normalized by drainage area. Tenth percentile error bound is 0.720 . Ninetieth percentile error bound is 1.600 .

${ }^{6}$ Coefficient of variation of daily flows. Tenth percentile error bound is 0.780 . Ninetieth percentile error bound is 1.220 . 
Publishing support provided by:

Rolla Publishing Service Center

For additional information concerning this publication, contact:

Director, USGS Kansas Water Science Center

4821 Quail Crest Place

Lawrence, KS 66049

(785) 842-9909

Or visit the Kansas Water Science Center website at: https://ks.water.usgs.gov 

\%

4 a

(1)

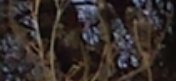

1) 12
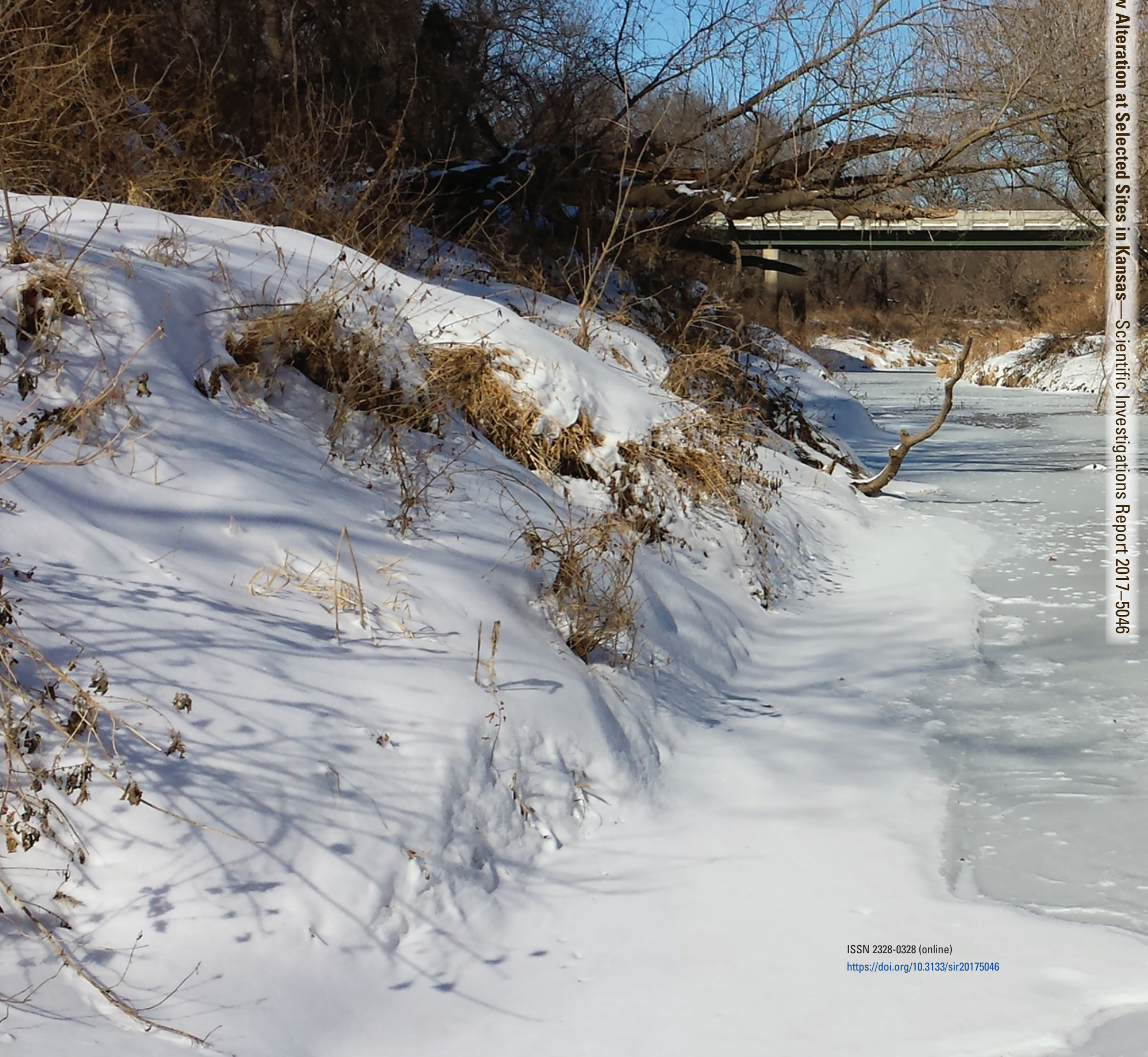